Portland State University

PDXScholar

Dissertations and Theses

Dissertations and Theses

$1-1-1985$

\title{
Municipal water use: an Oregon case study
}

Ibrahim M. Shukri

Portland State University

Follow this and additional works at: https://pdxscholar.library.pdx.edu/open_access_etds Let us know how access to this document benefits you.

\section{Recommended Citation}

Shukri, Ibrahim M., "Municipal water use: an Oregon case study" (1985). Dissertations and Theses. Paper 523.

https://doi.org/10.15760/etd.523

This Dissertation is brought to you for free and open access. It has been accepted for inclusion in Dissertations and Theses by an authorized administrator of PDXScholar. Please contact us if we can make this document more accessible: pdxscholar@pdx.edu. 
MUNICIPAL WATER USE: AN OREGON CASE STUDY

by

IBRAHIM M. SHUKRI

A dissertation submitted in partial fulfillment of the requirements for the degree of

DOCTOR OF PHILOSOPHY

in

URBAN STUDIES

Portland State University

1985 
TO THE OFFICE OF GRADUATE STUDIES AND RESEARCH:

The members of the Committee approve the dissertation of

Ibrahim M. Shukri presented January 21, 1985.

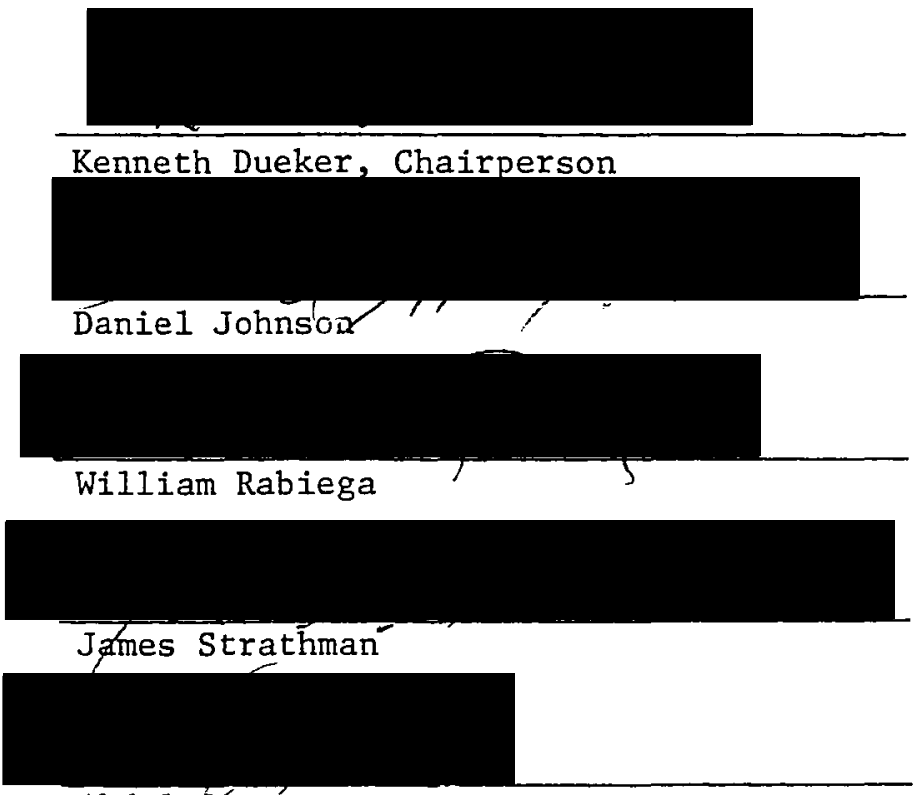

Abdul Q́áyum

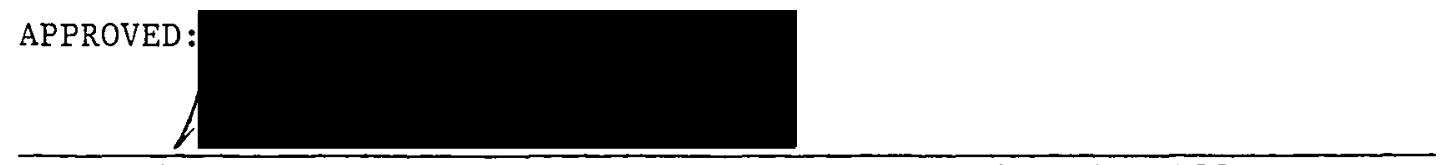

Kenneth Dueker, Acting Dean, School of Urban and Public Affairs

Jim F. Heath Bean of Graduate Studies and Research 
AN ABSTRACT OF THE DISSERTATION OF Ibrahim M. Shukri for the Doctor of Philosophy in Urban Studies presented January 21, 1985.

Title: Municipal Water Use: An Oregon Case Study

APPROVED BY MEMBERS OF THE DISSERTATION COMMITTEE:

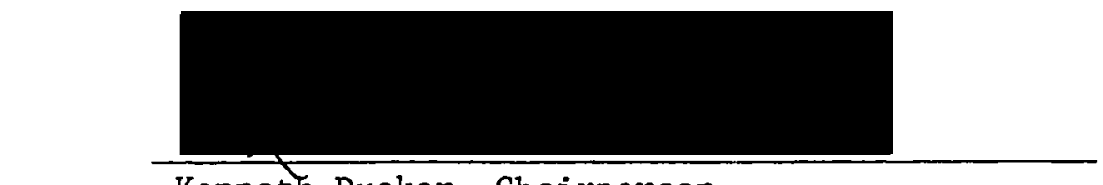
Kenneth Dueker, Chairperson

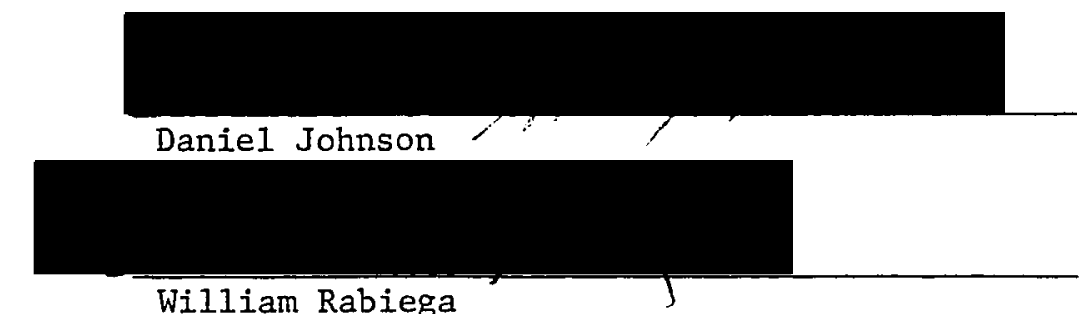

William Rabiega

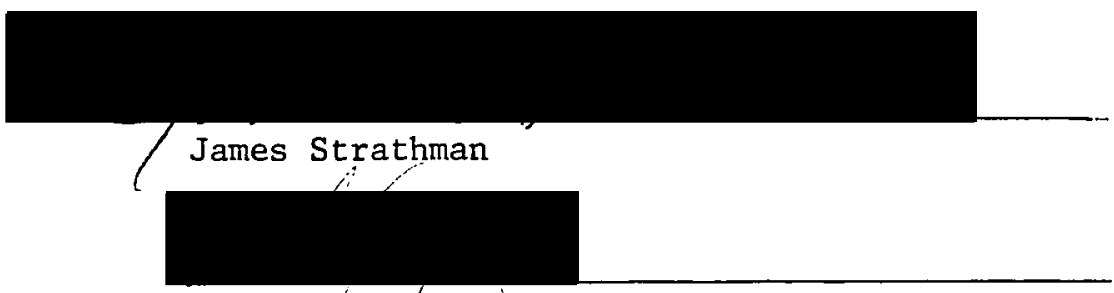

Abdul Qáyumy

There are two approaches to estimating the quantity of water required in an urban area: the requirements approach and the economic approach. The requirements approach extrapolates from past growth trends of the urban area. Water consumption and population are extrapolated into the future using a trend line based on prior years; the future requirements of the area are determined according to past experience. This approach served well when water was essentially a free good. But now that it is an economic good that requires production, the requirements approach tends to overestimate water requirements. 
The altnerative is the economic approach which takes into account different characteristics of an urban area. Among these characteristics are economic, demographic, geographic and climatic. This approach leads to better use of information to estimate future water consumption.

This dissertation is a cross-sectional analysis of municipal water districts in Oregon. It is based on the economic approach. Data on specified variables were collected by sampling and surveying more than 1,000 water districts in Oregon. The data were analyzed using Multiple Linear Regression.

The general hypothesis of the study is that municipal water use in Oregon can be estimated by using indpendent variables other than size. Weather, per capita income, average price of water, marginal cost of water, the amount of fixed charge for basic water use, allowed quantity of basic water use, and non-residential connections were regressed on the per capita per day water consumption for residential, commercial, industrial and total users.

The hypothesis was confirmed; price was a significant variable in the different uses of water. Climate was found to be significant in estimating the residential use. Variable charge as well as climate were found to be significant in commexcial use. Fixed charge and sewage charge were somewhat significant in estimating the industrial use.

The results of the study are consistent with the theory and the findings of previous studies. Three models were developed; a general model, a residential model and a non-residential model. These models helped to identify climate and price as effective variables in estimating water demand in the study area within the context of the economic approach. 


\section{ACKNOWLEDGEMENTS}

It is a challenging experience going through the different stages and processes of preparing, writing and defending a dissertation. Passing through this experience was possible with the assistance and cooperation of many public and private agencies and individuals to whom I would like to express my great appreciation and thanks.

It gives me pleasure to express my gratitude to the University of Petroleum and Minerals for giving me the opportunity to follow my graduate studies in the United States and to the faculty of Urban Studies program and the participating academic departments at Portland State University.

I would like to express my special recognition to the enlightenment and wisdom of Professor Kenneth Deuker which helped me to conceptualize and formulate the dissertation. I thank him for the valuable time he spent patiently in reviewing the details of each step of my work and pointing to me my mistakes from the stage of designing the survey letters and processing the data on the computer to the stage of reviewing several drafts of the written dissertation document.

I would like to thank Professor James Strathman for his enlightening guidance and his knowledgeable and sincere suggestions. I would like to thank him for allowing me to present my research in the Research Seminar which meets weekly and for his efforts in contacting acquaintances at the University of Iowa and providing me with special research manuscripts. 
TABLE OF CONTENTS

\section{CHAPTER}

I INTRODUCTION . . . . . . . . . . . . . . . . I

Purpose of the Study ............... 3

Approaches of Estimating Water Demand . . . . . . 5

Requirement Approach

Economic Approach

II LITERATURE REVIEW . . . . . . . . . . . . . . . . 7

Techniques of Estimating Water Demand . . . . . . . 14

Deterministic vs. Non-Deterministic Models

Time-Series Analysis

Multiple Linear Regression Analysis

Simulation

Municipal Water Cost Structure . . . . . . . 20

Pricing Water: Theory . . . . . . . . . . 24

Marginal Cost Pricing

Long Run and Short Run Prices

Pricing Water: Practice ............. 33

Types of Rates . . . . . . . . . . . . . 36

Fixed Charge

Allowed Quantity

Block Rates

III RESEARCH DESIGN . . . . . . . . . . . . . . 46

Municipal Water Use in Oregon . . . . . . . . . . 46

Study Area

Municipal Water Supply

Variation in Municipal Water Supply

Sampling Procedure .............. 52 
Variables ................. 53

Dependent Variables

Independent Variables

Hypothesized Equations . . . . . . . . . . . 56

Conditions of Applying Regression Analysis . . . . . 57

IV ANAIYYSIS ................... 60

Average Price................... 61

Errors of Measurement .............. 67

Functional Form . . . . . . . . . . . . 68

Empirical Evaluation ............. . 71

Equations of the General Model . . . . . . . . 73

Equation (1)

Equation (2)

Equations of the Residential Model . . . . . . . . 77

Equation (1)

Equation (2)

Equations of the Non-Residential Model . . . . . . 79

Equation (1)
Equation (2)
Equation (3)
Equation (4)

$\mathrm{V}$ RESULTS AND CONCLUSIONS . . . . . . . . . . . . 86

Findings .................. 86

Policy Implications . . . . . . . . . . . . $8 \delta$

Implications for Further Research . . . . . . . . 90

BIBLIOGRAPHY ..................... 95 
APPENDIX . . . . . . . . . . . . . . . . . . 100

Contents . . . . . . . . . . . . . 100

Definitions . . . . . . . . . . . . . 102

Equation (1) . . . . . . . . . . . . 103

Data list

Descriptive statistics

Variable 1ist--mean, SD, correlation

Multiple regression

Equation (2)................. . 112

Data list

Descriptive statistics

Variable list--mean, SD, correlation

Multiple regression

Equation (3)................. . . 118

Data list

Descriptive statistics

Variable list--mean, SD, correlation

Multiple regression

Equation (4).................... 125

Data list

Descriptive statistics

Variable list--mean, SD, correlation

Multiple regression

Equation (5)................. 131

Data list

Descriptive statistics

Variable list--mean, SD, correlation

Multiple regression

Equation (6) . . . . . . . . . . . . . . 137

Data list

Descriptive statistics

Variable list-mean, $S D$, correlation

Multiple regression 
vii

Equation (7) ................. . 143

Data list

Descriptive statistics

Variable list--mean, SD, correlation

Multiple regression

Equation (8) .............. . . 149

Data list

Descriptive statistics

Variable list--mean, SD, correlation

Multiple regression 


\section{LIST OF TABLES}

\section{TABLE}

I List of Previous Studies . . . . . . . . . . . 13

II Coefficients of the Variables . . . . . . . . . 85 
LIST OF FIGURES

FIGURE

1. Short-run average and marginal costs . . . . . . 21

2. Long-run average and marginal costs . . . . . . 23

3. Perfect competition .............. 25

4. Monopoly . . . . . . . . . . . . . . . 27

5. Regulated monopoly break even . . . . . . . . . 28

6. Price is more than average cost (profit). . . . . . 29

7. Price is below average cost (loss) . . . . . . . . 31

8. Short-run and long-run prices . . . . . . . . . 32

9. Short-run pricing .............. 35

10. Increasing block rate . . . . . . . . . . . 37

11. Fixed charge . . . . . . . . . . . . . . . 39

12. Fixed charge with allowed quantity . . . . . . . . 41

13. Declining block rate . . . . . . . . . . . . 42

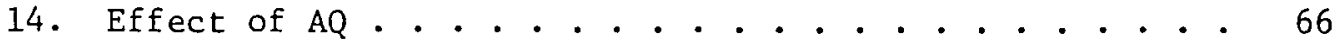

15. Segments of water use . . . . . . . . . . 70

16. Efficiency and Equity Illustration . . . . . . . . 92 
CHAPTER I

\section{INTRODUCTION}

As the process of urbanization continues, the demand for urban water will increase. The total amount of water furnished by public utilities in the United States has been increasing at a rate of 3.5 percent, from 3 billion gallons daily in 1900 to 22 billion gallons in 1970 (Baumann \& Dworkin, 1978). However, this rate has declined to 1.75 percent between 1960 and 1970 as a result of highly concentrated local demands and efficient use of water.

The increase in water demand may be attributed to three main factors: (1) an increase in urban population (it tripled from 1910 to 1960 from 42 million to 125 million), (2) water services were extended to the suburban areas, and (3) the per capita demand for water has risen as a consequence of improved living conditions.

One might add that the perception of urban water as an abundant inexpensive good leads to overuse and unnecessary use of water through negligence and leakage.

Better planning, efficient management and reliable projections of urban water demand became essential to build cost-effective water facilities which also need constant improvement to meet the increasing demands of urban water. Shortages of water have created problems for many communities, a situation which will be aggravated if current water management practices continue (Klugman \& Tobin, 1982). 
In spite of the money spent on water works each year, water facilities for collection, storage, processing, and transportation are not sufficient in quantity or quality. The problem is accentuated by curtailed investment in new and alternative water supplies because of the prohibitive costs. Also, supply and demand for urban water fluctuate over space and time; they are unevenly distributed, e.g., the demand on a river may occur at a time when annual fiow is at its lowest. Thus, the cost to supply piped water depends on the source. In many localities, available local sources have been developed already, especially surface reservoir sites. Water extraction from local aquifers often exceeds estimated safe yields (Klugman \& Tobin, 1982). The supply of piped water to suburban areas would increase the cost of distribution; and meeting the season, daily, and hourly peaks would increase the cost of storage facilities (Grima, 1972). The costs of meeting minimal acceptable standards of water are increasing as pollution of the environment increases and the limitations on the physical development of local resources are strict. For these reasons, and as cities increase in size, a more distant water source may have to be tapped as a result of stringent financial and environmental conditions. These considerations make matching demand and supply of urban water a production problem which involves spatial and temporal variations.

Economic factors play a great role in water resources development on the basis that water constitutes an economic good whic n requires allocation of resources for production. It also is an essential service that requires efficient and equitable distribution. For this reason, 
the prediction and explanation of the variation in the level of urban water use became the subject of many studies and the subject of this particular study.

PURPOSE OF THE STUDY

The purpose of this study is to construct a demand model for municipal water use in Oregon. The intent of building the model is to explain different consumptive patterns.

The model is a reflection of the need for more efficient use of municipal water facilities and resources. Technological changes have created efficiencies and advantages in operating water systems by providing economies of scale. But the dramatic cost increase in capital expenditure has offset the gains. This is why the orthodox requirements approach of estimating and forecasting municipal water demand, which has been satisfactory in the past, no longer serves the purpose.

The assumption that price of water and real income are constant for a given water district over the planning horizon is a concept overdue for revision. The fact that waterworks were able to hold down the price of water is because economies of scale and relatively low inflation rate offset the effect of high costs. Inflated costs of water production without increases in productivity produced relatively large changes in the real price of water. As a result of increases in real price without increases in real income, excess capacity exists and water systems face financial deficits. To consider past consumptive patterns and the rate of growth of population as the basic factors for forecasting water demand may result in inefficient allocation of resources. 
The estination of urban water demand has progressed fron the simple requirement approach to economic demand models for a homogeneous region or population to generalized multivariate models for entire regions or nations. The econonic demand model approach is not based on past trends in water use. It seeks to find other relevant factors to improve the demand estimates. These relevant factors influencing water demand are identified and the resultant model has greater applicability to similar regions. In fact, any size water district may use the model to estimate water demand given the coefficients of the variables. This study emphasizes the importance of considering geographic, social, climatic and economic factors in the estimation of the variables of the model. Data on the independent variables will be collected from a sample of water districts in Oregon and tested statistically for significant effect of variation on the dependent variables. The variables that best explain municipal water variation will be identified. Different categories of water use will also be examimed. In particular, residential, commercial and industrial uses will be tested in separate models. A general conclusion regarding the general application of the model will be stated.

APPROACHES OF ESTIMATING WATER DEMAND

Requirement Approach

The basic assumption in the requirement approach is that the rate per unit of consumption is constant. The intensity of water use can be 
measured by one variable such as population, dwelling units, or area of land. The amount of required water is simply determined by multiplying the number of units by the rate per unit. The rate per unit of water use is often based on engineering judgment. They base their estimation of water demand on limited aggregates and individual empirical evidence that an individual consumes 50 or 60 gallons of water per day and this consumption increases at a rate of one or two percent per year. On this rough estimate, they make the projection for a period of 10 or 20 years.

The requirement approach ignores the management variables such as price, metering, or restrictions on the assumption that people are willing to use water; and as long as water is considered a necessity and people are willing and able to pay for it, it will be provided regardless of overestimation and overinvestment.

The only criterion in the requirement approach is that total revenues cover the total cost plus a fair rate of return on the facilities after deducting the depreciation. The individual rates are based upon the allocation of the full costs and fairly distributing them among classes of consumers in proportion to the amount of water used (Milliman, 1962).

As long as the consumers are willing to purchase water, they are charged equally for the quantity they use. On this basis, the United States Senate Select Committee on National Water Resources suggested that prices should be constructed to cover what consumers use, not to reduce their consumption (U.S. Water Resources Council, 1978). Consequently, overinvestment in waterworks became a normal practice in order to insure availability of water at all times. 


\section{Economic Approach}

In the economic approach, water is considered an economic good that requires production and optimal allocation of resources. It requires efficient and equitable distribution. Optimal allocation of resources requires cost effective facilities. Efficient and equitable distribution requires fair pricing schemes. The determining factors such as population and area are still required in the economic approach. They are needed in determining total costs and equitable distribution of service.

It became necessary that realistic planning and estimating water use in urban areas should include certain types and numbers of variables in the projection which constitute the elements of the economic approach such as price, management, and other socio-economic variables. 


\section{CHAPTER II}

\section{LITERATURE REVIEW}

The importance of developing demand models for municipal water have been recognized by some authors. Gottlieb (1963) was one of the early authors who developed an economic model in 1963 to examine the effect of price on water use in Kansas. He studied water systems which charge different prices per 10,000 gallons of water. Prices varied from $\$ 2$ to $\$ 8$, depending on the finance policies of each water district and the different responses to inflation in each area and costing methods. Some districts price water to collect revenues for water improvements financed by revenue bonds. Some districts imposed excise taxation on water utilities to supplement property levies. He found that water use was reduced by 20 to $50 \%$ as an effect of price. He found the effect of climate and rainfall as well as the effect of air conditioning to be minimal because of the homogeneity of the study units. Headley (1963) used cross-sectional and temporal data to study the effect of income on water use in the San Francisco-0akland area. He found a linear relationship between median family income and water use. Grima (1972) used cross-sectional data to find the effect of price on residential water use in metropolitan Toronto. He showed that the total demand of water is curvilinear related to price, but the different segments of demand are linearly related. He showed that water demand 
increases at a decreasing rate with income and number of persons per dwelling unit. He used the multiplicative form to get constant elasticities of demand through the range of independent variables. He hypothesized that a structural relationship exists between average residential water use by individual households and a number of explanatory variables: value of the residence, size of the lot, price, fixed bill, size of the bill, and a disturbance factor. He postulated five hypotheses: A higher price results in a reduction of water use; the assessed value of the residence represents the income; the greatest use of water is for bathroom purposes, which is a linear function of the number of persons in the residence; more bills in a year means more water use; if the amount of the bill is high, frequent billing reduces water use.

Wong (1972) used a cross-sectional and temporal data to study the effect of price, income and temperature on municipal water demand in Chicago and 59 of its suburbs. He pointed to three problems in conducting studies of water consumption. The literature on urban water demand was scant. The data on income was estimated by proxy variables such as assessed property value, number of appliances, etc. The third problem was the lack of a uniform price in public water. This particular problem of municipal water rates has been referred to as the "most unscientifically determined price in the public utility" (Lawrence \& Hines, 1969). Sample size was a problem in conducting such studies. The period of five years or less may be too short in time-series analysis; in the cross sectional study, the sample of six or seven observations may be too small. 
The results of the above study were that temperature was significant at the level of $1 \%$ error. Income elasticity was insignificant although it was higher in the suburbs' cross-sectional data than in Chicago time series data. Price elasticity was low in smaller communities, but larger in Chicago using time series data. Higher price elasticities in larger communities reflect the cost of ground water in contrast to the supply of smaller communities from surface water. In the study, multiple $R$ was low and so was the explained variance, $R^{2}$. The variance ratio (F-value) was high and there was no explanation of the residual variance.

Primeaux and Holman (1973) used data from 14 cities in Mississippi to estimate a statistical model. They excluded income as a variable and included instead numerous colinear variables. They found that the primary surrogate of income (market value of residence) was insignificant. Its elasticity coefficient was very low because of its interdependency with other explanatory variables. Multicolinearity made it difficult to determine the specific effect of any of the highly correlated variables.

Darr, Feldman, and Kamen (1975) found that many demographic and socioeconomic factors influenced urban water demand.

A11 the above studies found that price is an important factor in its effect on water use. Although Grima demonstrated that a small segment of the total water use by a household is essential and was not affected by price.

Hanke (1970a) observed that metering and price are related. He found that areas without metering have a higher water use per capita 
than those with metering. The evidence cited by Hanke (1970b) confirms the instances of reduced water use as a result of metering, including some from the 1940s (American City, 1946a, 1946b).

Temperature and precipitation have been used as a measure of climate. Thornthwaite built a model to estimate effective precipitation. His model is based on the rate of evapotranspiration, absorption of the water by the soil, and actual precipitation.

However, Morgan and Smolen (1976) found that temperature and rainfall provided the best specification for climatic variables in their estimation of municipal water demand. When they tested the three climatic variables--temperature, precipitation, and effective precipitation--to determine which explained the most variance in their water use data, they found that temperature and precipitation outperformed effective precipitation.

Other climatic variables used are: evaporation (Young, 1973), Thronthwaite's evapotranspiration measure (Howe \& Linaweaver, 1967; Berry \& Bouern, 1974; Billing \& Agthe, 1980), and number of daylight hours (Hansen \& Narayanan, 1981). Water use may rise considerably during the summer in hot dry climates, and climatic factors may play an important role unless the precipitation is high and sprinkling is not a major component of total water use (Klugman \& Tobin, 1982).

It can be hypothesized that temperature, daylight hours, evapotranspiration and evaporation are all positively correlated with water use, while precipitation is negatively correlated. Some of these variables may explain a large degree of variance in water use in time series data, 
but may not explain a great variance in cross-sectional data in small or homogeneous areas.

Fourt (1958) in a generalized model tried to estimate water quantity delivered to dwelling units. He regressed the quantity on policy, number of days of rainfall in summer, average number of persons per meter and total population. The results were not significant because of gross estimation of variables.

Foster and Beattie (1979) used the same model of Fourt to build a generalized model. Their results were significant, although they have been criticized by Griffin, Martin, and Wade (1981) on the specification of price in their model.

Grima (1972, 1973; Morgan 1973; Foster \& Beattie, 1979) found that the amount of water used per dwelling unit is positively correlated with the number of persons living in the dwelling unit, but per capita use of water declines as the number of persons per dwelling unit increases. Number of persons per household explains significant variance at the individual household level (Danielson, 1979).

Most of the above studies dealt with cross-sectional or time series models in which the data were aggregated over a temporal unit (i.e., a season or a cycle) or a spatial unit (i.e., a water district, a city or a region). The unit of observation in the aggregated models is usually large enough to include subcategories. In the case of the quantity of water observed on the level of the water district, it included industrial, commercial and residential uses. The exogenous effect of the category of water use can be identified but the endogenous effect among the types (i.e., industrial, commercial and residential) 
may not be identified due to the aggregation of data. The same thing can be said about socio-economic factors if they were treated as a category. In the aggregated models, the exogenous effect of the socio-economic category can be identified but not the endogenous effects among the numerous components of the socio-economic category (i.e., lifestyle, education, income).

The data in the disaggregated models is gathered on a small unit of observation (i.e., a household, a dwelling unit, peak period, winter or summer). Disaggregated models deal with homogeneous data (i.e., homeowners or renters, middle income or upper income, large families or small families).

Both types of models can be used in the study of water use depending on the purpose of the study. Aggregated models can be used in the case of identifying factors or categories for policy and planning purposes. If the purpose is predicting a magnitude of a factor for the purpose of equity, then disaggregated models are more suitable. Aggregated models are concerned with shifts in the demand curve while disaggregated models are concerned with the rate of change in the demand curve. Both types can be used for prediction but disaggregated models are more accurate in prediction. 
TABLE I

LIST OF PREVIOUS STUDIES

\begin{tabular}{|c|c|c|c|c|}
\hline Investigator & Year & Type of Analysis & $\begin{array}{c}\text { Price } \\
\text { Elasticity }\end{array}$ & $\begin{array}{c}\text { Income } \\
\text { Elasticity }\end{array}$ \\
\hline Metcalf & 1926 & $\begin{array}{l}29 \text { Waterworks Systems } \\
\text { Cross-sectional }\end{array}$ & -0.65 & \\
\hline $\begin{array}{l}\text { I,arson \& } \\
\text { Hudson, Jr. }\end{array}$ & 1951 & $\begin{array}{l}15 \text { Illinols Communtties } \\
\text { Cross-sectional }\end{array}$ & & 0.70 \\
\hline $\begin{array}{l}\text { Hanson \& } \\
\text { Hudson, Jr. }\end{array}$ & 1956 & $\begin{array}{l}8 \text { Illinois Communities } \\
\text { Cross-sectional }\end{array}$ & & 0.55 \\
\hline $\begin{array}{l}\text { Seidel \& } \\
\text { Bauman }\end{array}$ & 1957 & $\begin{array}{l}\text { American Cities } \\
\text { Cross-sectional }\end{array}$ & $\begin{array}{l}-0.12 \text { to } \\
-1.0\end{array}$ & \\
\hline Fourt & 1958 & 34 American Cities & -0.39 & 0.28 \\
\hline Renshaw & 1958 & $\begin{array}{l}36 \text { Water Service Systems } \\
\text { Cross Sectional }\end{array}$ & -0.45 & \\
\hline Mil11man & 1963 & Speculation & $\begin{array}{l}-0.3 \text { to } \\
-0.4\end{array}$ & \\
\hline Gottlieb & 1963 & $\begin{array}{l}\text { Kansas } \\
\text { Cross-sectional }\end{array}$ & $\begin{array}{l}-.66 \text { to } \\
01.24\end{array}$ & $\begin{array}{l}0.28 \text { to } \\
0.58\end{array}$ \\
\hline Wong, et al. & 1963 & $\begin{array}{l}\text { Northeastern Illinois } \\
\text { Cross-sectional }\end{array}$ & $\begin{array}{l}0.01 \text { to } \\
-0.72\end{array}$ & \\
\hline Headley & 1963 & $\begin{array}{l}\text { S.F.-Oakland, 1950-59 } \\
\text { Time-series }\end{array}$ & & $0.0^{\text {to }}$ \\
\hline $\begin{array}{l}\text { Gardner \& } \\
\text { Schlck }\end{array}$ & 1964 & $\begin{array}{l}43 \text { No. Utah Water Systems } \\
\text { Cross-sectional }\end{array}$ & -0.77 & \\
\hline Flack & 1965 & $\begin{array}{l}54 \text { Western Cities } \\
\text { Cross-sectional }\end{array}$ & $\begin{array}{l}-0.12 \text { to } \\
-1.0\end{array}$ & \\
\hline Bain, et al. & 1966 & $\begin{array}{l}41 \text { California Cities } \\
\text { Cross-sectional }\end{array}$ & -1.099 & \\
\hline Howe \& Linnaweaver & 1967 & $\begin{array}{l}35 \text { Study Areas } \\
\text { Cross-sectional }\end{array}$ & $\begin{array}{l}-0.21 \text { to } \\
-0.23\end{array}$ & $\begin{array}{l}0 . \text { to }^{\text {to }} \\
0.37\end{array}$ \\
\hline Conely & 1967 & $\begin{array}{l}24 \text { S. Californian Communities } \\
\text { Cross-sectional }\end{array}$ & $\begin{array}{l}-1.02 \text { to } \\
-1.09\end{array}$ & \\
\hline Turnovsky & 1967 & $\begin{array}{l}19 \text { Massachusetts Towns } \\
\text { Cross-sectional }\end{array}$ & $\begin{array}{l}-0.05 \text { to } \\
-.40\end{array}$ & \\
\hline Grima & 1970 & $\begin{array}{l}91 \text { Observations } \\
\text { Cross-sectional }\end{array}$ & -0.93 & 0.56 \\
\hline \multirow[t]{2}{*}{ Wong } & 1970 & $\begin{array}{l}\text { Chicago, 1951-1961 } \\
\text { Time-series }\end{array}$ & $\begin{array}{l}-0.02 \text { to } \\
-0.28\end{array}$ & $\begin{array}{l}0.20 \text { to } \\
0.20\end{array}$ \\
\hline & & $\begin{array}{l}\text { Four Com. Sz. Groups } \\
\text { Cross-sectional }\end{array}$ & $\begin{array}{l}-.26 \text { to } \\
-0.32\end{array}$ & $\begin{array}{l}0.48 \text { to } \\
1.03\end{array}$ \\
\hline Andrews \& Gibbs & 1975 & Cross-sectional (Household) & $-0.51,-.62$ & \\
\hline B1l1ings \& Agthe & 1980 & Time-series (system) & $-0.27,-.61$ & \\
\hline Dantelson & 1977 & Puoled (household) & -0.305 & \\
\hline Foster \& Beattie & 1979 & Cross-sectional (system) & $-0.22,-.67$ & \\
\hline Grunewaid, et al. & 1975 & Cross-sectional (system) & -0.92 & \\
\hline Young & 1973 & Time-series (system) & $-.41,-.62$ & \\
\hline
\end{tabular}

Sources: Wong, S. T., 1972, A model of Munic1pal Water Demand: A Case Study of Northeastern 111 no1s. Land Econoinics, 48(1), 34-44. Young, C., Kinsley, K., \& Sharpe, W., 1983, Impact on Residential Water Consumption of an Increasting Rate Structure. Water Resources Bullet 1n, 19(1), 81-86. 


\section{TECHNIQUES OF ESTIMATING WATER DEMAND}

Estimating water demand is required for planning and building urban water systems and determining the management of water resources and their extent for pollution control, investment in developing new resources and conservation measures.

There are about 150 techniques of estimating future water demand. These techniques differ on the basis of their accuracy and their relative cost. An accurate projection technique with high probability of accuracy is more costly than a technique of low probability. The choice of the technique may require a cost-benefit analysis to arrive at the appropriate one. A community, through cost-benefit analysis, can balance the benefits derived from the avoidance of a surprise shortage or drought situation against the costs of over investment. The investment in accurate projection techniques is a function of the risk of being wrong in either direction. But there is no risk undertaken if water is viewed as a fixed component with total demand calculated on the basis of the size of the community and the average water use based on past experience.

\section{Deterministic vs. Non-Deterministic Models}

A deterministic model deals with variables whose future variance is completely determined by their past process. And the quality of the remote past is as good a predictor of the future as the recent past. In technical terms, the variance in the error in prediction is less than the variance of the actual lagged regression of the variable on its past. When the variance of the error in predicting the future 
process of a variable approaches the variance of its lagged process, then the future prediction may be incomplete and the assumption that the past process of water use completely determines its future is wrong. Non-deterministic models, on the other hand, explain the variance by using explanatory variables rather than by limiting the explanation to temporal factors. The variables are selected on the basis of their ability to explain the variance in water use.

Some of the early studies selected particular variables which contributed to better estimation of water demand. The results, however, of these studies were not compatible due to differences in selecting the explanatory variables and the design of sampling.

The technique of projecting future water requirements can be grouped under three major categories: time series analysis, multiple regression analysis and simulation. These categories will be discussed below.

\section{Time Series Analysis}

This technique is based on the assumption that forecasting future trends can be extrapolated from historical data, and the temporal variability of water use can predict its future use.

The extrapolation can be graphic or arithmetic. It is an adequate technique for long range estimation provided that historical data exist and the dependent variable has only time as its predictor. In pure time series extrapolation, only the trend of the past observation is considered. No account is taken of social, economic, technological or industrial variables. The effect of such variables is regarded as noise 
or error to predicted values. For this reason, methods of smoothing the series have been practiced to find the best fit for historical data, either by moving averages or by ratio methods to estimate the coefficients of a similar geographic area.

Long range linear extrapolation of time series is limited by unknown factors which change nonlinearly with the passage of time. This fact had been noticed a long time ago by Verhulst (Baumann \& Dworkin, 1978) when he proposed logarithmic curve fitting in 1837. The idea was accounted for later by the "limits of growth" of Pearl when he observed the growth of fruit flies in a jar. In the beginning, the flies multiplied rapidly; but as space and food became scarce, the rate of the increase declined.

This implies that deterministic models (the future is determined completely by the past experience) are good for short-run prediction. The choice of time series as a technique for water prediction depends on the conditions of the area. If historical data exist and environmental and socioeconomic factors are relatively stable, then the technique is good for prediction purposes (Foster \& Beattie, 1974). But if the costs of water production are increasing without corresponding increases in the economies of scale, time series prediction is not adequate. Other techniques of estimation are required which consider the changing conditions in the area such as income, price, and demographic fluctuations.

\section{Multiple Linear Regression Analysis}

When historical data are nonexistent, cross-sectional data can be utilized. Cross-sectional studies investigate the problem within 
a spatial framework rather than on a temporal basis. This involves comparing water consumption data of different communities on the basis of the effect of the variance of the identified variables. The difference between time series studies and cross-sectional studies is that time-series involve regressing the dependent variable on its lag time to estimate the coefficient of its future use. Crosssectional studies involve regressing the dependent variable on other independent variables and estimating their coefficients at any point in time. So, in the absence of adequate historic data for extrapolation, multiple linear regression which uses explanatory socioeconomic and climatic variables is an adequate technique.

Multiple linear regressions are based on the least square estimates

of the coefficients of the independent variables to find the best fit for the dependent variable.

The least square estimates are based on certain mathematical assumptions which should be fulfilled before applying the regression technique.

The first assumption is the matrix of the independent variables must have a rank less than the number of the independent variables so that the inverse of the matrix of the independent variable exists; the number of the cases must be larger than the number of the variables, including the dependent variable. This assumption is required to guarantee the linear independence of the explanatory variables (Domokos, et al., 1976). 
The second assumption is that the mean of the errors (disturbance) in estimating the coefficients of the independent variables is zero; the number of pluses is equal to the number of minuses around the mean; the errors in estimating the coefficients are normally distributed. This is to guarantee that the regression equation can be evaluated statistically by placing bounds on the limit of confidence or by calculating other statistics.

The third assumption is that the errors of the estimate are independent of each other for each point in time, that is the error of estimating the coefficient in time one is independent of the error of estimating the coefficient in time two and so on.

The above assumptions are referred to as linearity, the independent variables do not contribute jointly to the variation in the dependent variable, homogeneity of variance, normal distribution of variance of errors, serial independent of errors; that is, errors are uncorrelated over time.

However, if the explanatory variables are correlated among themselves, interpreting the results of the regression analysis is difficult even if the above assumptions are satisfied. The imprecision occurs mathematically when one explanatory variable correlates with another. As this correlation, or colinearity becomes perfect, the variance of the elements, in the principal diagonal of the matrix approaches zero and the variance of the inverse would approach infinity, the variance of the least square coefficient cannot be determined (Domokos, et al., 1976). 
In cross-sectional models, the types of variabies and the level of aggregation of data is important. Some variables such as temperature and precipitation may explain a great deal of variance in the quantity of water if the data is aggregated on heterogeneous units such as water districts spread over a large area, such as a region. But the above variables may not explain much of the variance if the data is gathered on small units such as households in a small homogeneous area, such as a city.

Simulation

Simulation is a technique of building a system of models. A system is composed of components and the changes in the system depend on the changes in the components. For example, population forecasting models consist of three components: birth, death, and migration. Each component is a function of one or more variables.

Water forecasting simulation models may include as components technological change, urban development and hydrologic cycle. Another simulation model may include as components zoning regulations, housing trends, and consumer education campaigns.

When the components are assigned probabilities of occurrence, the model is known as the probability distribution model. A certain probability is assigned to the lack of education campaign or the lack of urban development. The concern in the probability distribution is the uncertainty of occurrence rather than predicting a single number representing future demand.

The failure of occurrence of the assigned probability helps to overcome over-investment and facilitates staged development of waterworks. 
Probability distribution models are not easy to build. Estimating certain probabilities to failure of occurrence requires comprehensive evaluation of all components.

Holistic simulation models consist of all components known to affect demand, including scenarios about the future and the probable changes in the components. Everything is integrated to estimate future demand. This type of model is being paid great professional attention as the leading forecasting technique and the science of looking ahead (Baumann \& Dworkin, 1978).

\section{MUNICIPAL WATER COST STRUCTURE}

Water production is a short run average cost declining industry. This is because a heavy initial outlay is involved and small outlay is spent annually for operation and maintenance (Figure 1). However, this decline in average cost, $\mathrm{SRAC}_{1}$, continues until the capacity is reached at $\mathrm{A}$. When the average cost is declining throughout the range of output, marginal cost, $\mathrm{SRMC}_{1}$, is always below average cost and marginal cost pricing below A would result in a loss (Grima, 1972, p. 129; Foster \& Beattie, 1979 , p. 260). Another cycle of addition of capital for storage, source development or other facilities starts when the capacity is reached at $A$ and another expansion of the system is required. Shortrun average cost rises again to $C$ and declines to $B$ after a period of adjustment (Grima, 1972).

The average cost is the total expenditure divided by total consumption. It is affected by fixed cost, variable cost, operation, scale, source treatment, distance, big consumers, and peak demand. Because 


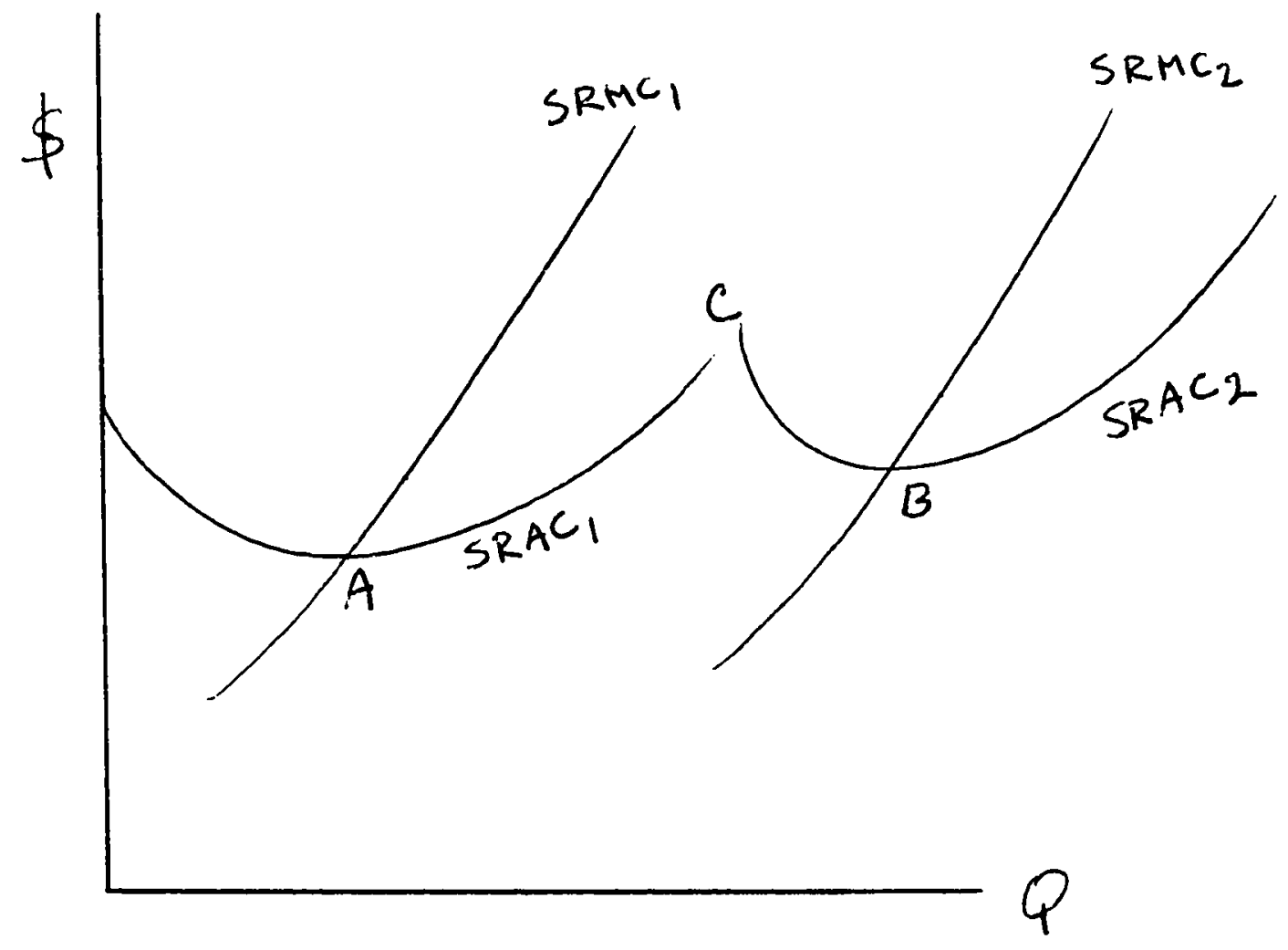

Figure 1. Short-run average and marginal costs 
of these composite effects, average costs differ from one district to another even if they deliver the same quantity and quality of water.

In the long run, average cost is an increasing function and the production of municipal water is an increasing average cost industry due to higher cost of each additional source from wells or rivers, costly treatment, further distance, etc.

Economies of scale are effective in the long run but their effect is on the allocation of the total system investment. It has been estimated that the allocation of expenditures on the development of basic sources is partitioned as follows: $30 \%$ to develop basic resources, $20 \%$ transmission and treatment costs, $50 \%$ for local distribution and local storage (Grima, 1972; Foster \& Beattie, 1979).

For each water district there is an actual cost due to the expansion of the system (Figure 2). Each ( $\mathrm{SRAC}_{1}, \mathrm{SRAC}_{2}, \mathrm{SRAC}_{3}, \mathrm{SRAC}_{4}$ ) is a short-run cost for the industry as a whole. The cost of addition to capacity to make supply meet demand is the marginal cost (SRMC ${ }_{1} \mathrm{SRMC}_{2}$. $\mathrm{SRMC}_{3}, \mathrm{SRMC}_{4}$ ). It is an opportunity cost of interruption of service for some users. If there is excess capacity, marginal cost should equal zero. In theory, marginal cost does not include any of the fixed or operation costs. But in practice marginal cost equals the expected incremental cost incurred by excess demand to available capacity. It is not the actual cost of the unit but the expected cost of that unit in excess of the capacity.

If capacity additions took place in the short run to meet the demand of peak users, these users should bear the cost since the marginal cost for non-users is zero. However, any excess capacity in the short 


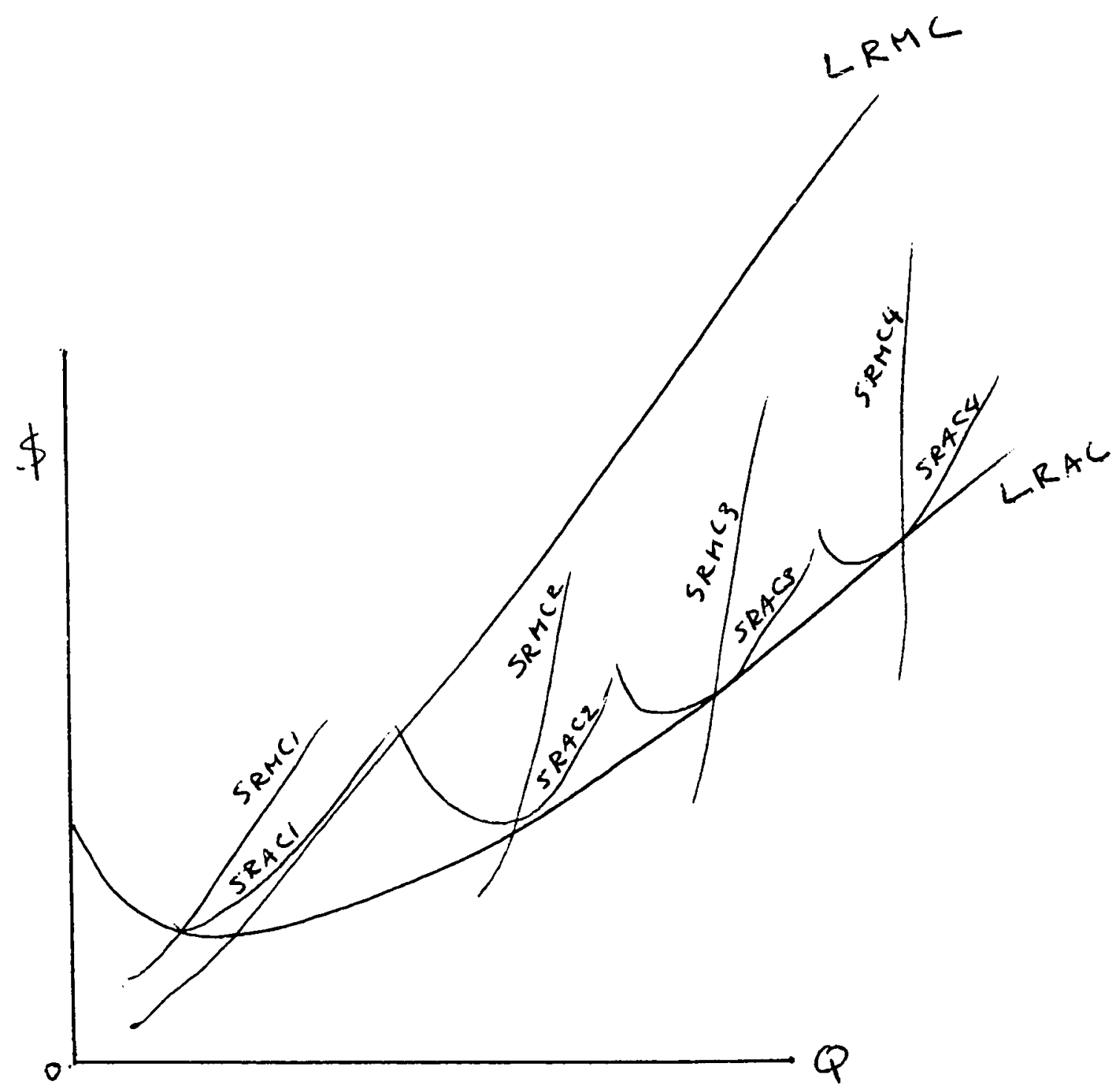

Figure 2. Long-run average and marginal costs. 
run is a long-run addition to capacity. Therefore, the non-peak users should pay a marginal cost for the long run addition to caracity.

The long run marginal cost, LRMC (Figure 2), should include all types of costs, i.e., transmission, reservoir, source and water loss costs. Prices, equally should reflect in the long-run incremental cost of capacity, running costs and long-run marginal cost caused by addition to capacity (Grima, 1972; Foster \& Beattie, 1979).

PRICING WATER: THEORY

Marginal Cost Pricing

Pricing theory provides the guidelines for the efficient use of scarce resources among alternative uses.

In a competitive market for a commodity where there are many producers and many consumers, producers should charge a price equal to the cost of any additional unit to be produced in order to have marginal revenue equal marginal cost, $M R=M C=P$ (Figure 3 ). At a higher price, the consumer will not buy any additional unit, because the consumer reached his utility at that price. At a higher price, he would reduce the quantity or find a substitute at a lower price.

The producer is facing a constant demand, $D$, and the limit to the quantity the producer supplies is the cost. He can supply a quantity, Q, at which $M C=M R=A C$ at $A$. At this equilibrium position, $\mathrm{TR}=\mathrm{TC}$. Demand is elastic; any change in price would shift the demand curve. 


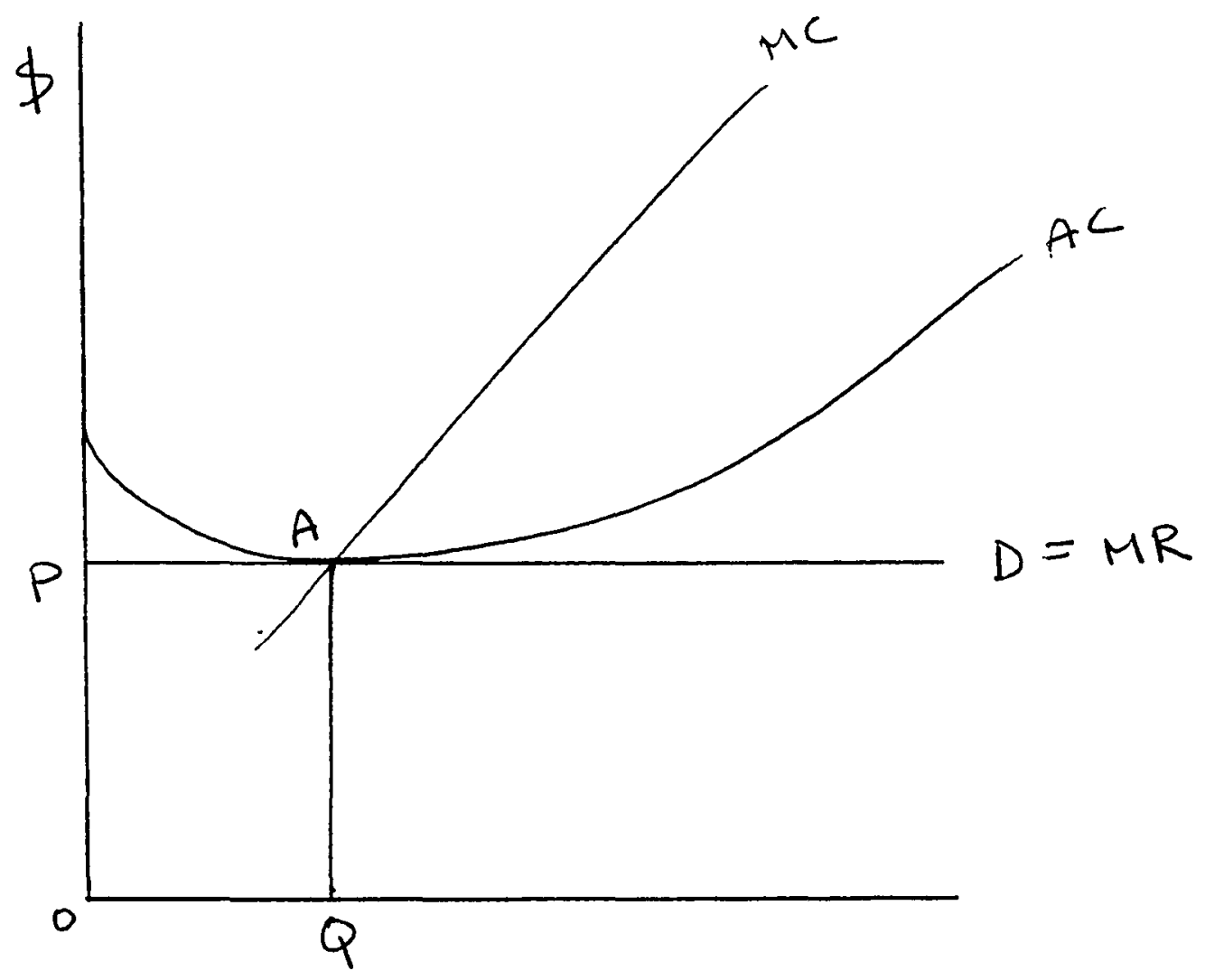

Figure 3. Perfect competition. 
In a monopolistic market (Figure 4) there are few producers and many consumers. Prices are set where profit is maximized. It is where $M C=M R$. It is not the efficient situation where supply meets demand. An efficient situation is where supply meets demand and average revenue covers average cost. The efficient situation in a perfect market is where supply meets demand and $M C=A C$. Price $P_{M}$ is set where $M R=M C$ and the quantity is limited to $O Q$. At $A$, a profit is realized in addition to recovering actual costs. A more efficient situation in the market is where average revenues cover average costs at B, provided there is a consumer surplus to be captured. An average price $P_{A}$ would reduce the profit and increase the output to $\mathrm{OQ}_{1}$. It is a break-even point. The above situation depicts the behavior of a private enterprise working in a monopolistic market. A little output is supplied at a very high price.

But in a regulated monopoly, the efficient situation is sought. It is where supply meets demand and average revenue covers average cost (Figure 5). The price $\mathrm{P}_{1}$ is set where the quantity supplied is Q. The break-even point for the regulated monopoly is where $M C=A C$ and $A R=A C$. At $Y$ there is no loss or profit. When the price is set when average cost is falling, $(M C<A C)$, a profit realization is possible. if $\mathrm{AR}=\mathrm{AC}$. When prices are set when average cost is rising $(\mathrm{MC}) \mathrm{AC}$ and $\mathrm{AR}<\mathrm{AC})$ a loss occurs.

Figure 6 shows where a profit is realized in a regulated monopoly. If price $P_{I}$ is set where average revenue (D) is above the average cost, a profit is realized if $P_{1}=M C$. The unit of actual cost is $B Z$ and the total cost is the area $(X Z B O)$. The total profit is the area $\left(P_{1} S Z X\right)$. There is room for increasing the output from $B$ to $A$ and reducing the 


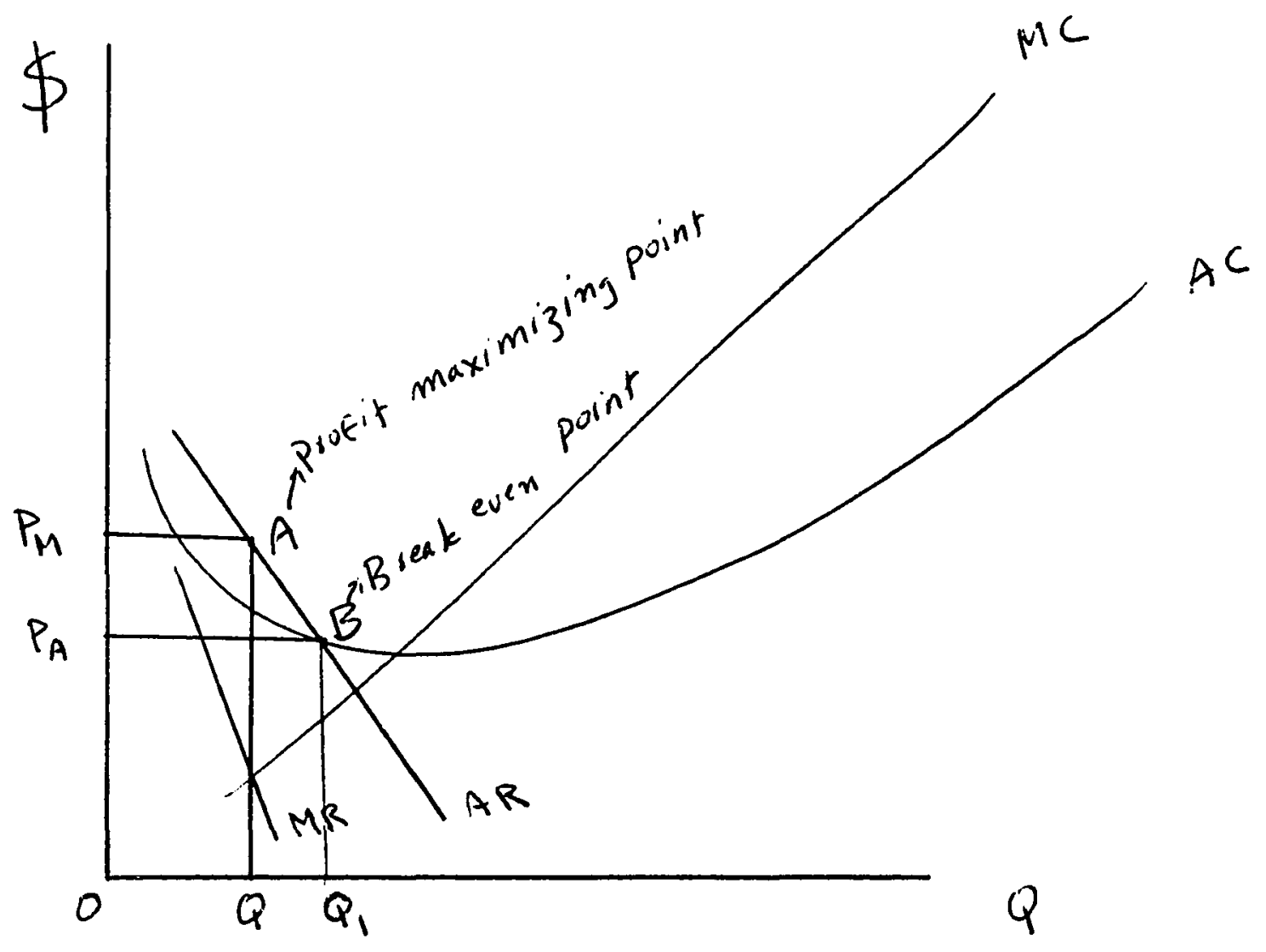

Figure 4. Monopoly 
28

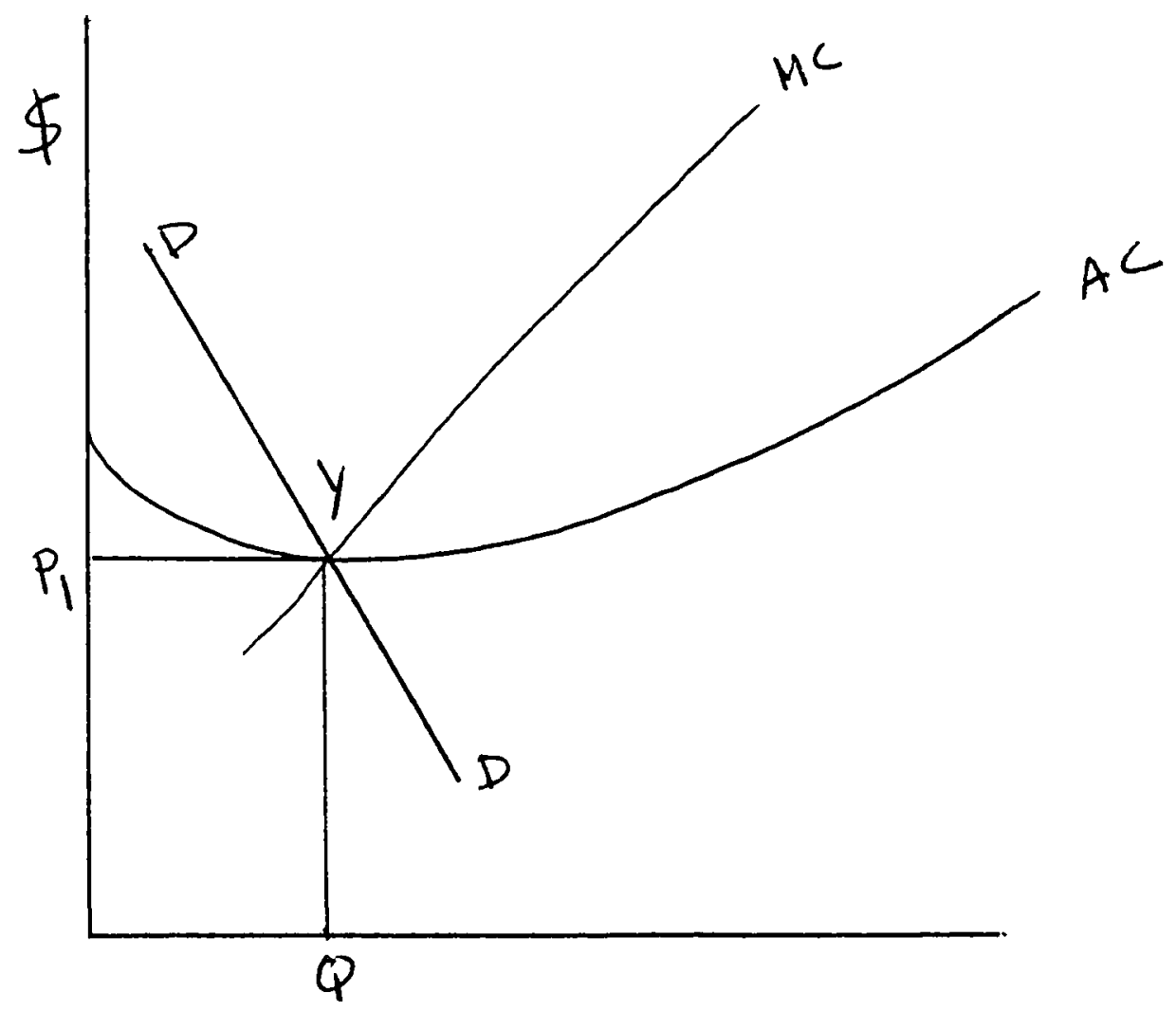

Figure 5. Regulated monopoly break even. 


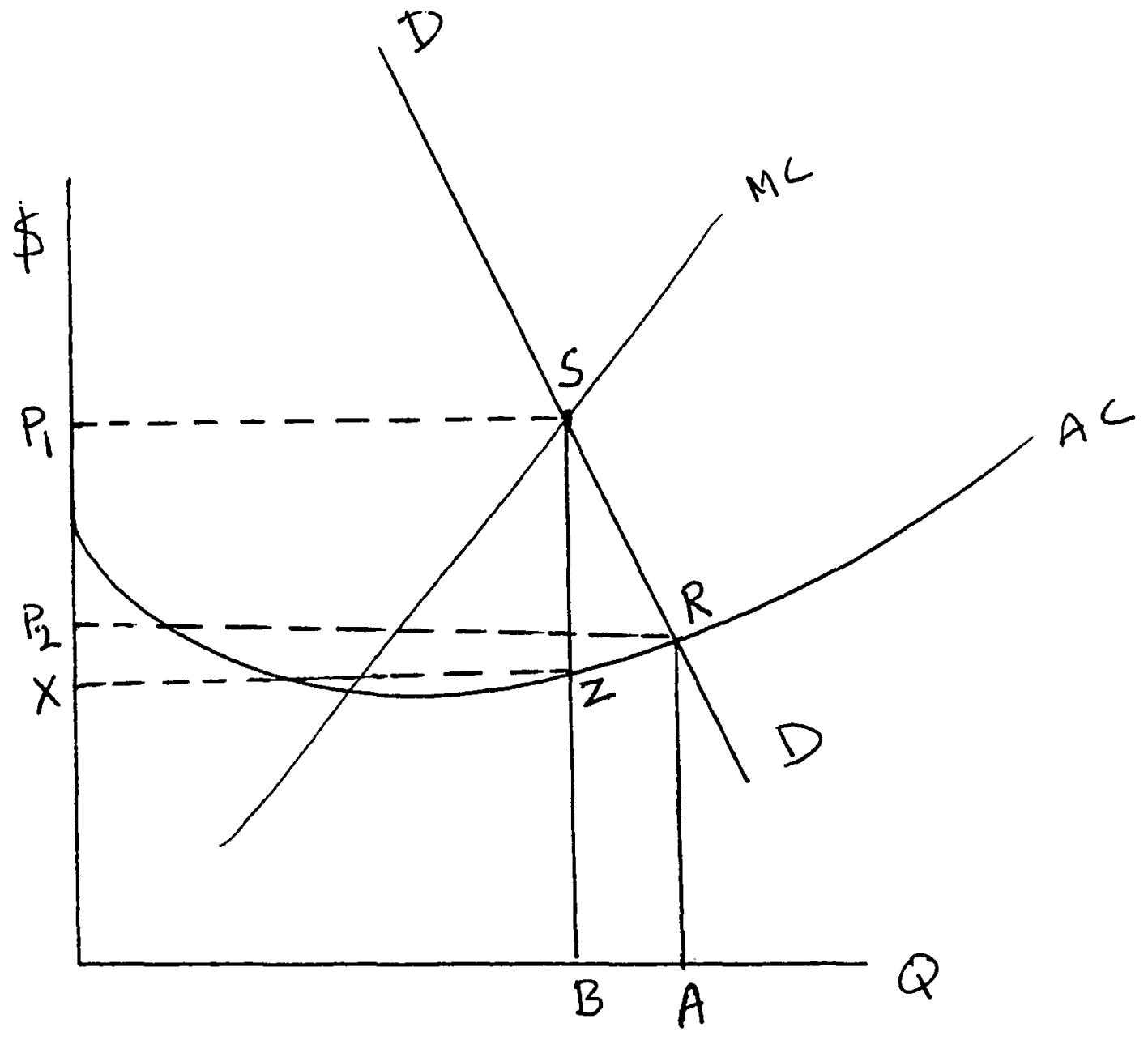

Figure 6. Price is more than average cost (profit). 
price to $\mathrm{P}_{2}$ without incurring a loss. At $\mathrm{R}, \mathrm{AR}=\mathrm{AC}$. If the price is set where $M C=A C, D$ will give more revenue and the output would be less. There is a profit but there is a consumer surplus which needs to be captured.

The opposite situation is depicted in Figure 7. The price $\mathrm{P}_{1}$ is set where average cost is higher than average revenue. At $S$, average cost is falling (MC $C A C$ ) and because average revenue at $S$ does not cover the cost, with a unit loss of SR, a total loss equals the area $\left(\mathrm{XRSP}_{1}\right)$. A more efficient situation can be realized where the price $P_{2}$ is set where $M R$ covers average cost at $V$. If the price is set where $M C=A C$, the loss would be greater, because the difference between AR and $\mathrm{AC}$ would be greater. When average cost is falling, it does not pay to set a price equal to marginal cost. The loss could be made up by charging each customer a small lump sum (Grima, 1972).

Long Run and Short Run Prices

In theory muncipal water should be priced as any other commodity. The price should be at a point where $M C=M R$, which yields a situation where total revenues equal total costs. This point is reached in the short run when the capacity of the plant is reached. It is the point when the expansion in the plant is required to increase supply. At this point, marginal cost equals the addition to the total cost in order to make supply meet demand. This cost is an opportunity cost to prevent the interruption of the service to some users. However, the accounting convention utilizes a proxy to this marginal cost. It is the increase in cost for excess capacity to reduce the probability of service interruption. It is the cost of a unit above capacity where it is equal to zero at capacity. 
31

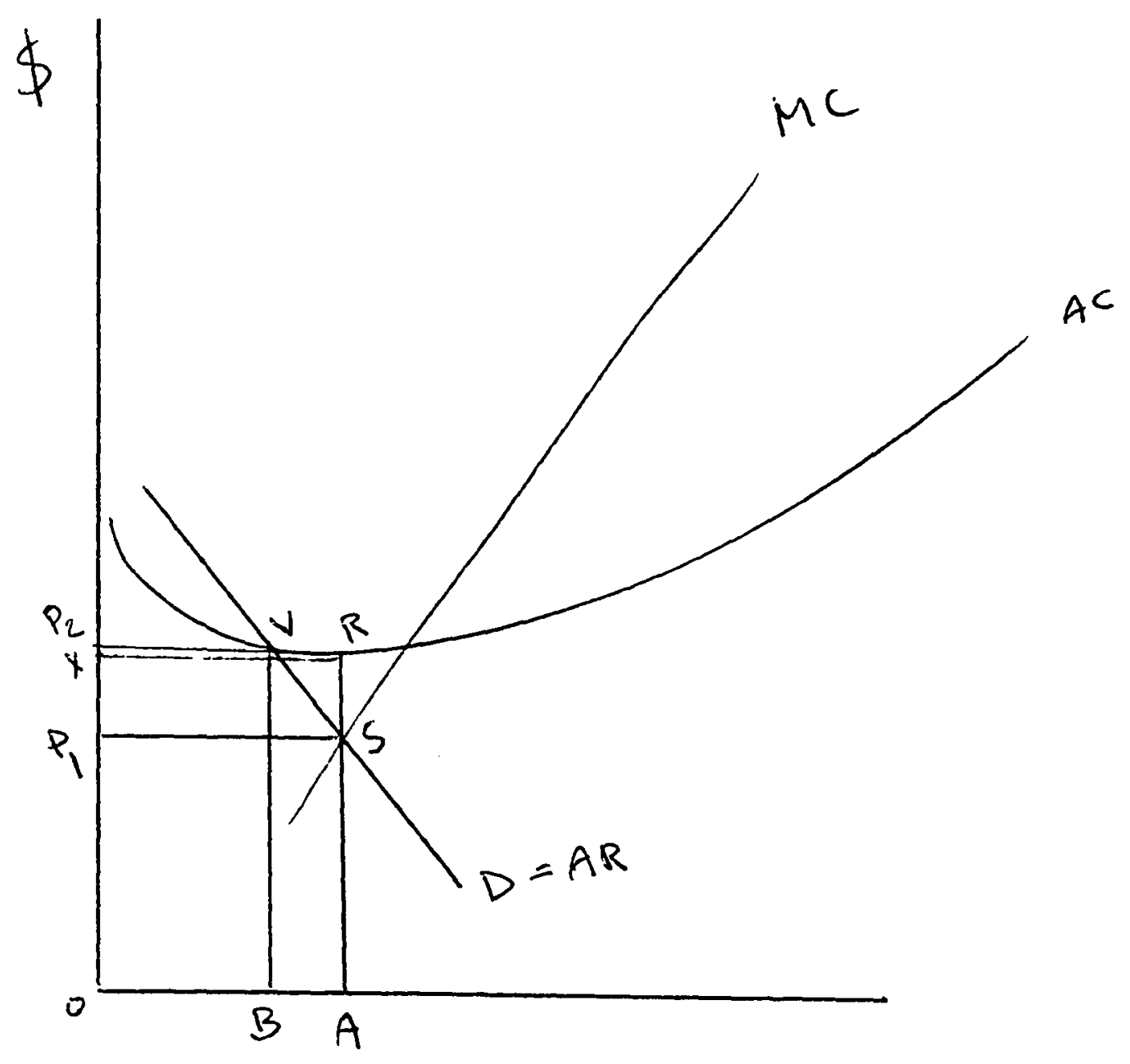

Figure 7. Price is below average cost (loss). 
In the short-run when the capacity is reached and where average cost, $\mathrm{AC}=$ marginal cost, $\mathrm{MC}$, Price $\mathrm{P}$ should equal marginal cost, $\mathrm{MC}$.

Suppose the plant kept expanding from capacity 1 to 2 to 3

(Figure 8). At capacity 3 , the plant reached its optimal size; shortrun average cost $\mathrm{SRAC}_{3}=$ Short-run marginal cost $\mathrm{SRMC}_{3}=$ Price $\mathrm{P}_{0} \cdot$ The short-run price meets the quantity demanded $Q_{0}$ at $B$.

Pricing below $\mathrm{P}_{0}$ where $\mathrm{SRMC}_{3}$ is below $\mathrm{SRAC}_{3}$ would result in excess expenditure and a loss; pricing above $\mathrm{P}_{0}$ where $\mathrm{SRMC}_{3}$ is above $\mathrm{SRAC}_{3}$ results in excess revenue.

If the demand curve $D$ is expected to be $D " D "$ and expansion is expected to take place, $\mathrm{SRMC}_{3}$ would increase. For the production of $Q$, the long run price would be $\mathrm{P}_{1}$ where $\mathrm{P}_{1}=$ LRMC. This price would equal the short run price under marginal cost pricing. The long run average cost LRAC is increasing function and long run pricing should be based on the long run marginal cost, LRMC. At $\mathrm{P}_{1}$ long run total cost equals long run total revenue.

It is in line that the water districts charge a price above the $P_{0}$ in anticipation for expansion and arrive at a long run price $P_{1}$. Long run average cost at $E$ under the demand curve $D^{\prime \prime} D$ " is higher than $\mathrm{SRAC}_{3}$ but increasing at a decreasing rate due to economies of scale.

PRICING WATER: PRACTICE

It is a matter of policy for the water district concerned whether to charge short-run marginal cost or long-run marginal cost as a price for water. Short-run marginal cost involves shifting up and down as the plant grows. As the capacity is reached and an expansion is required, 


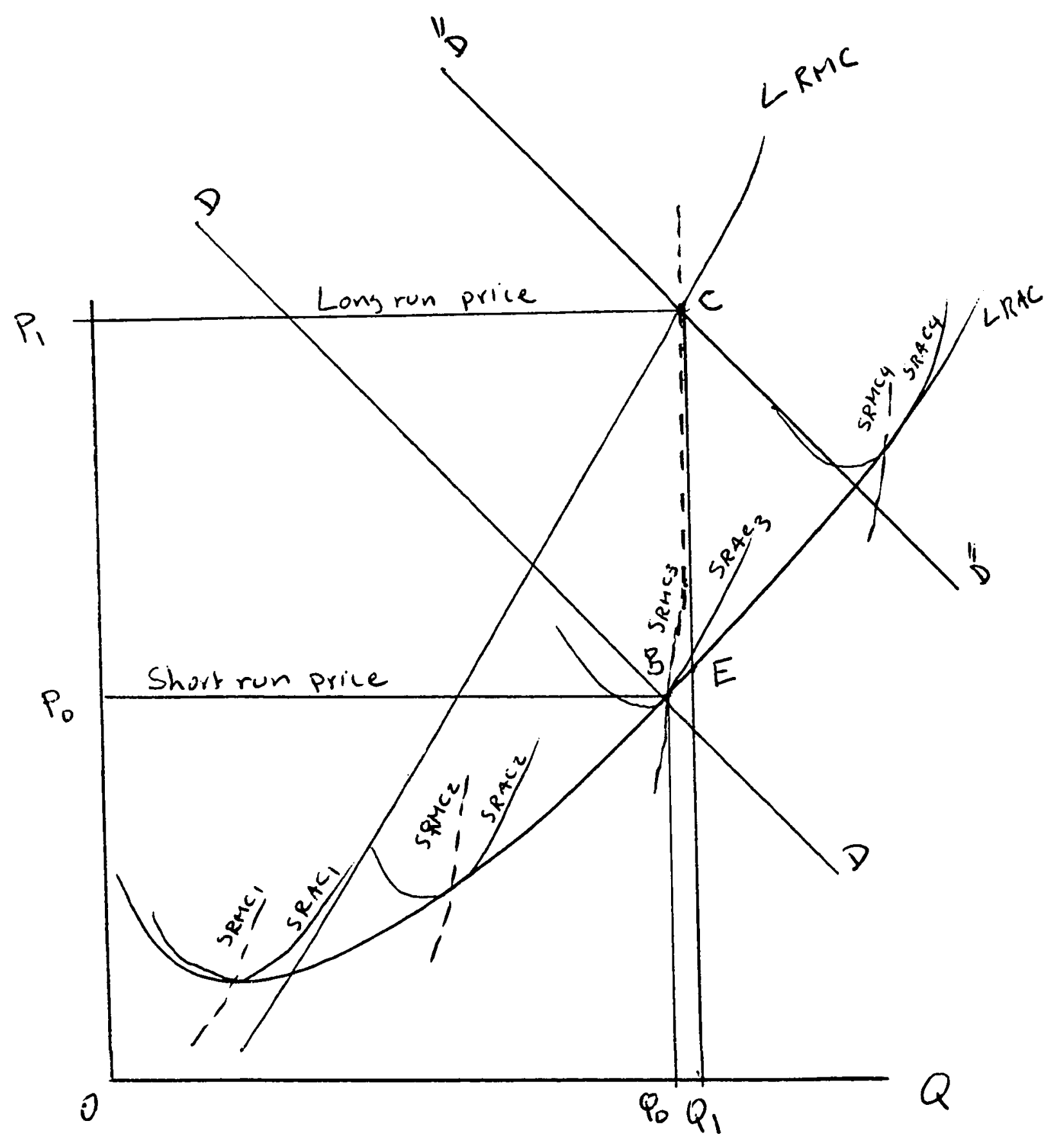

Figure 8. Short-run and 1ong-run prices. 
price is minimum at the margin. When expansion takes place, average cost increases and the prices rise at the margin.

After the expansion, short-run average cost declines and the shortrun marginal cost is below it, but long-run marginal cost is above the long-run average cost. This justifies charging the long-run marginal cost as a short-run price as a rationing device before the expansion takes place. Long-run marginal cost is easier to administer. Instead of following the direction of the short-run curve, long-run marginal cost is applied and a short-run excess in revenue is realized. If the shortrun average cost is declining, price may be put at a fixed charge to collect sufficient revenues to meet expenditure and a variable charge at a declining block rate to capture the consumer surplus.

A single price based on long-run marginal cost would result in revenues exceeding expenditure all the time. A free allowance of water may be a solution to reduce excess revenues. When short-run marginal cost reaches the long-run marginal cost, the allowed quantity could be dropped. Fixed charge is justified when short-run marginal costs are lower than average costs (Figure 9). Instead, pricing at B, a fixed charge is added at A. At this point, fixed charge would cover some of the high fixed costs. A fixed charge with a declining block rate encourages some users to use more water and can result in great peak demands. Abolishing fixed charges and allowed quantity may reduce water use but may require increasing the variable charge. When MC is above average cost, fixed charge is not justified because fixed capital and operating costs are paid for by VC. There is no need to pay a fixed charge; water should be treated like bread and milk. 
35

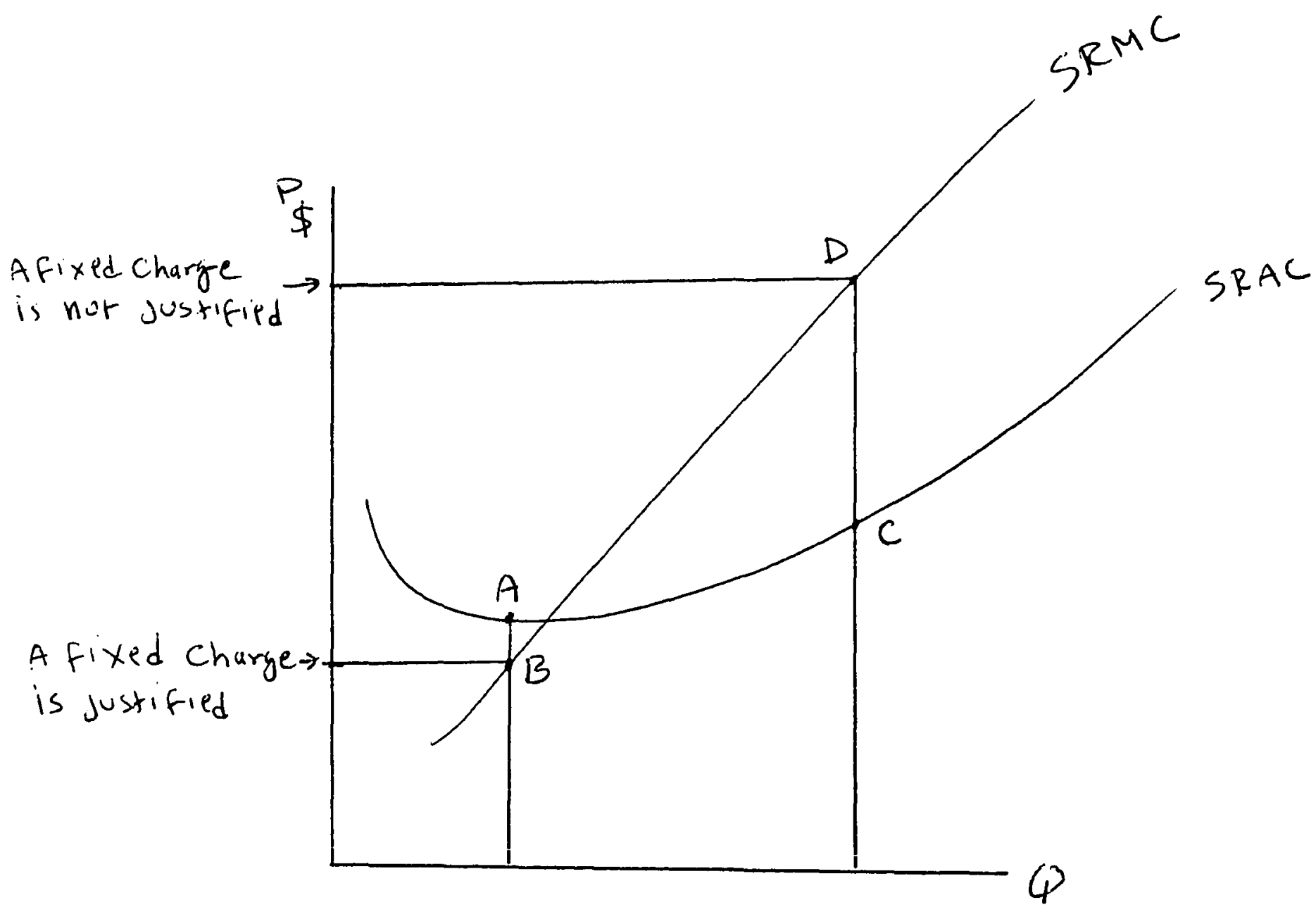

Figure 9. Short-run pricing. 
If price is at $B$, a fixed charge is required to capture consumer surplus. If price is at $D$, a fixed charge is not required because profit is realized at $D$ and all costs are covered at $C$, average cost. At $B$, fixed costs are not covered; at $A$ and $C$ all costs are covered.

Increasing block prices are justified in the long-run when marginal cost is rising and increasing capacity satisfied luxurious demand. It is unfair to charge small users for the extra capacity which is very costly. Therefore, it is better to have increasing block prices (Figure 10). Suppose that in the long run $M C=A C$ at $A$; then price should at least equal $\mathrm{P}_{2}$. If quantity increases to $Q_{2}$, then the cost would be Cost $_{2}$; if the quantity increases from $Q_{2}$ to $Q_{3}$, the cost of this increase would be $\operatorname{Cost}_{1}-\operatorname{Cost}_{2}$. For this cost, a price for this block is established at $\mathrm{P}_{1}$. In this way, those who choose to buy more pay more. This idea is explained by Grima (1972) in his argument of the equity of rate structure.

\section{TYPES OF RATES}

Municipal water is a commodity produced and sold by a monopoly which acts as a trustee of public good. Price is set according to the objectives of those administering the utility. A manifestation of these objectives includes:

1. Recovering expenditures;

2. Subsidizing certain users (new industry to expand tax base);

3. Leaving a small margin of the profit to taxpayers in order to expand later without difficulty;

4. To use part of the profit to reduce the level of municipal taxation (water is a municipal service that could be operated at a profit); 


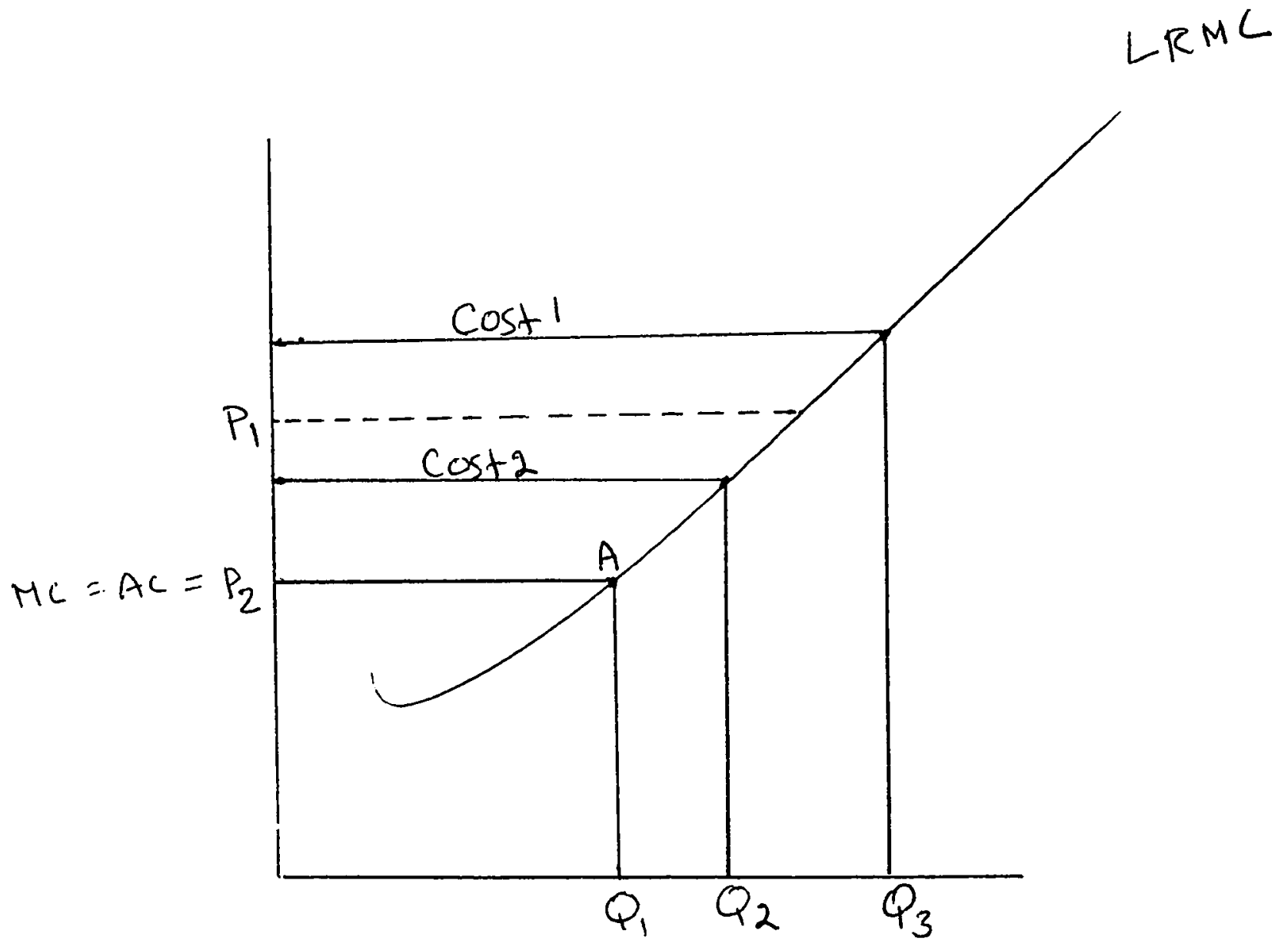

Figure 10. Increasing block rate. 
5. Redistributing income;

6. Equating marginal utility to marginal cost for efficient allocation of resources; and

7. As an administrative tool to reduce demand.

The most manifested objective is recovering the total cost. This price is calculated by dividing total cost by average amount of water sold. It has been criticized because it is based on average pricing to satisfy the condition of collecting enough revenues to cover total cost without solving the problem of fair and equitable distribution of the costs among different users. It might not be fair to charge the big user for capacity and storage as the small user or peak user. Should the near source user be charged for transmission and distribution for the far source user? If the first unit is charged a high rate in order to reduce total usage, big users are penalized and a decreasing rate may promote more water use!

For the above reasons, water rates are based on trial and error. It is difficult to find the logic behind the structure of water rates. Most of the water districts surveyed used one of three schemes of water rates.

Eixed Charge

Most of the water districts that meter water charge a fixed charge per month. This charge is intended to cover the fixed costs, including the meter and the line of service. In a few districts, this charge also included the sewage charge. If it includes the sewage charge, it is usually higher than the fixed charge of water districts that have separate sewage districts (Figure 11). 


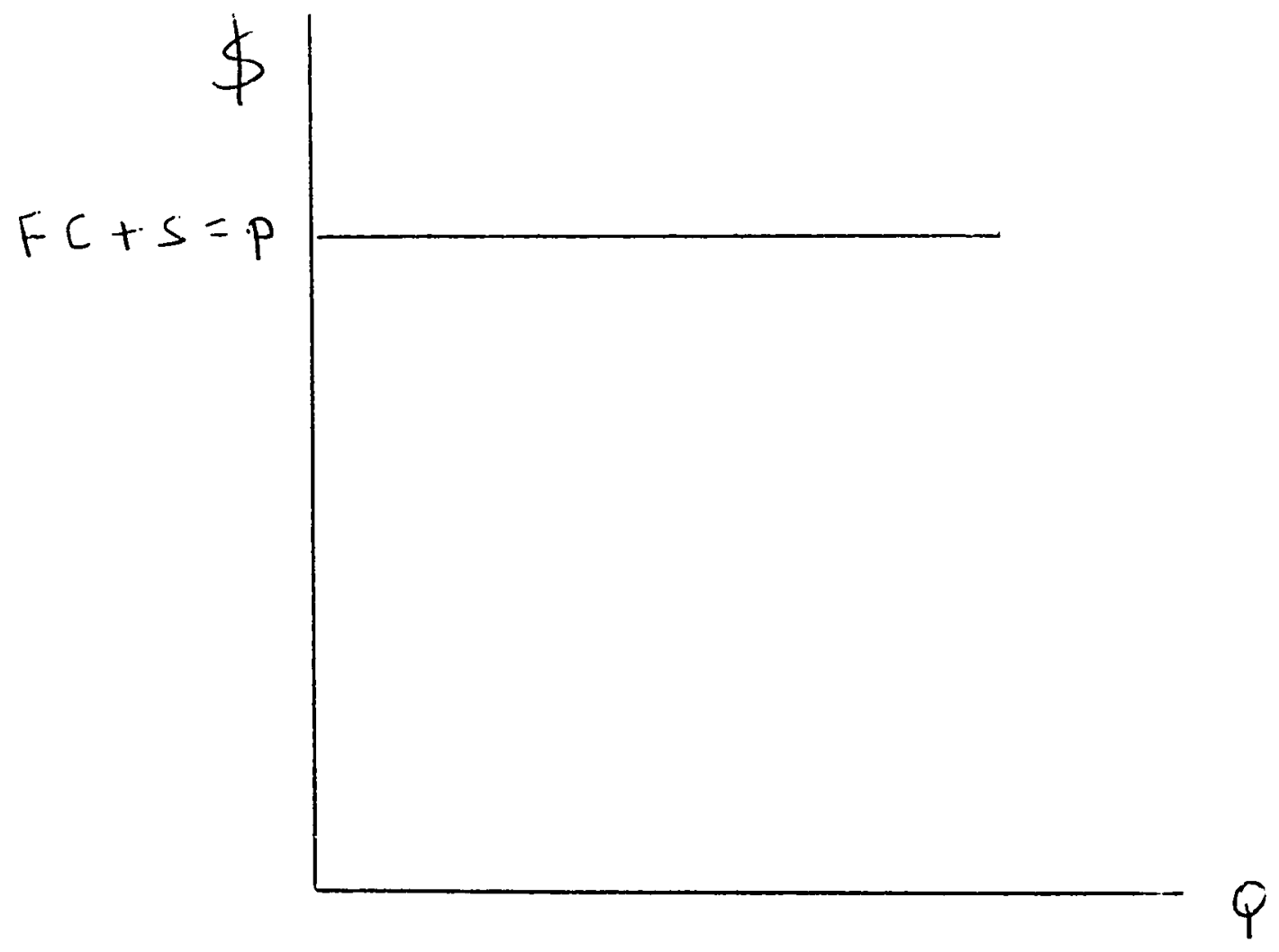

Figure 11. Fixed charge. 


\section{Allowed Quantity}

Another type of rating is the allowance of a certain quantity of water AQ with the fixed charge (Figure 12). This allowed quantity depends on the financial status of the water district and its objectives in rate setting. A free quantity usually represents a compensation for excess revenues or a fair treatment of small users who bear a part of the costs for the sake of big users. After AQ, a variable charge VC is charged for peak and big users. If the average fixed charge within $A Q$ is equal to the $V C$ in the first block, there will be no tendency to use less water.

The small user will exceed $A Q$ if it is small and big users will not cut part of their use. It is possible that water districts that have excess capacity and which are not pressed for new resources tend to structure their rates in this manner.

Block Rates

A third type of rating is the water districts that charge fixed charges with allowed quantities and a declining block rate charge (VC). The fixed charge ranges from $\$ 6$ to $\$ 30$ per month. This type of water district rating is found in the big districts where the long-run cost of expansion has taken place and where equitable pricing is the concern. $\mathrm{AQ}$ is large and $\mathrm{VC}$ is based on declining block rate. There is no pressing need to increase capacity; pricing is promotional to capture consumer surplus (Figure 13).

The above pricing schedules are arbitrary in many instances, promotional to the big users and discriminating against small users. The theory behind price setting is to meet widely fluctuating customer 


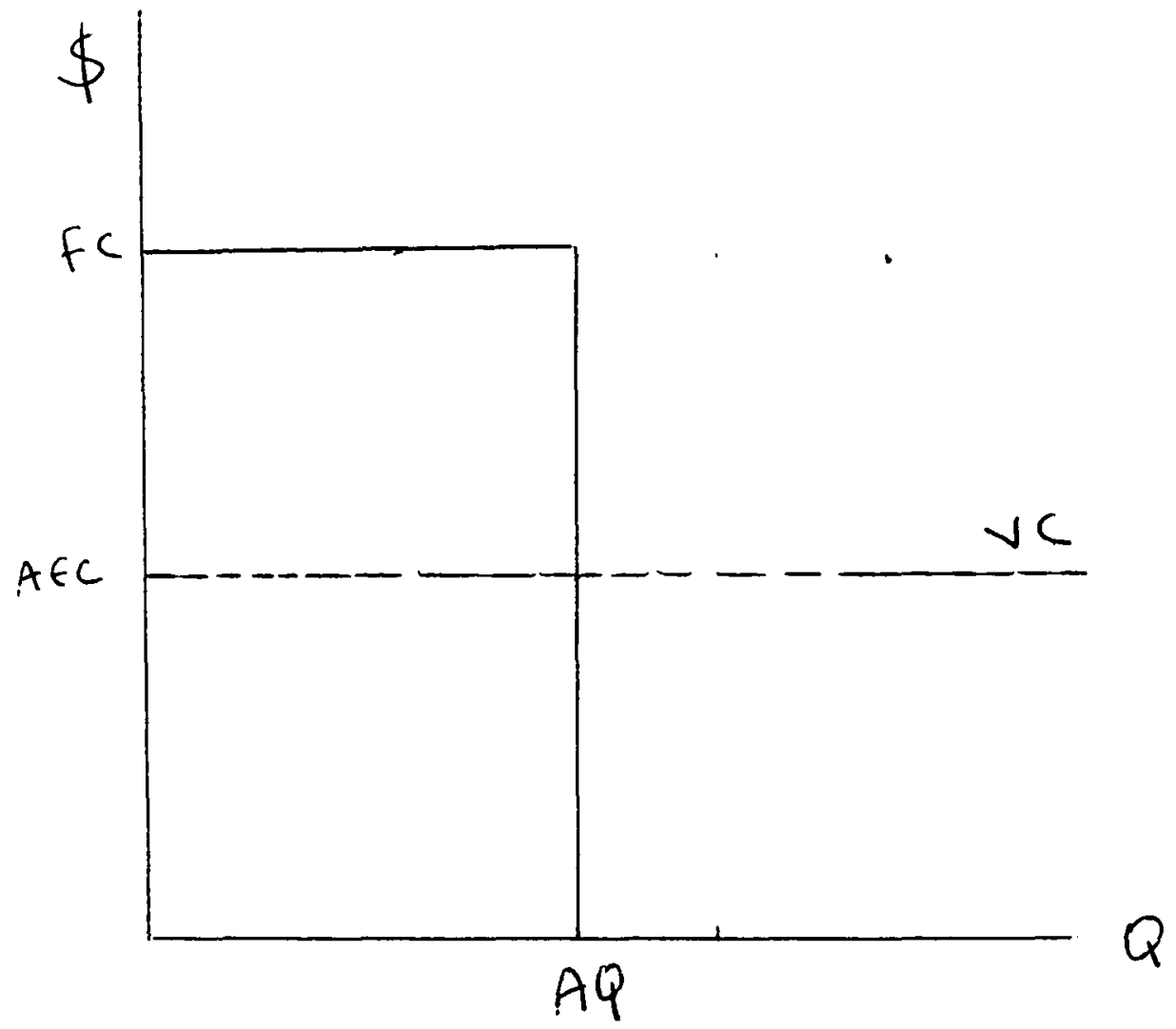

Figure 12. Fixed charge with allowed quantity. 


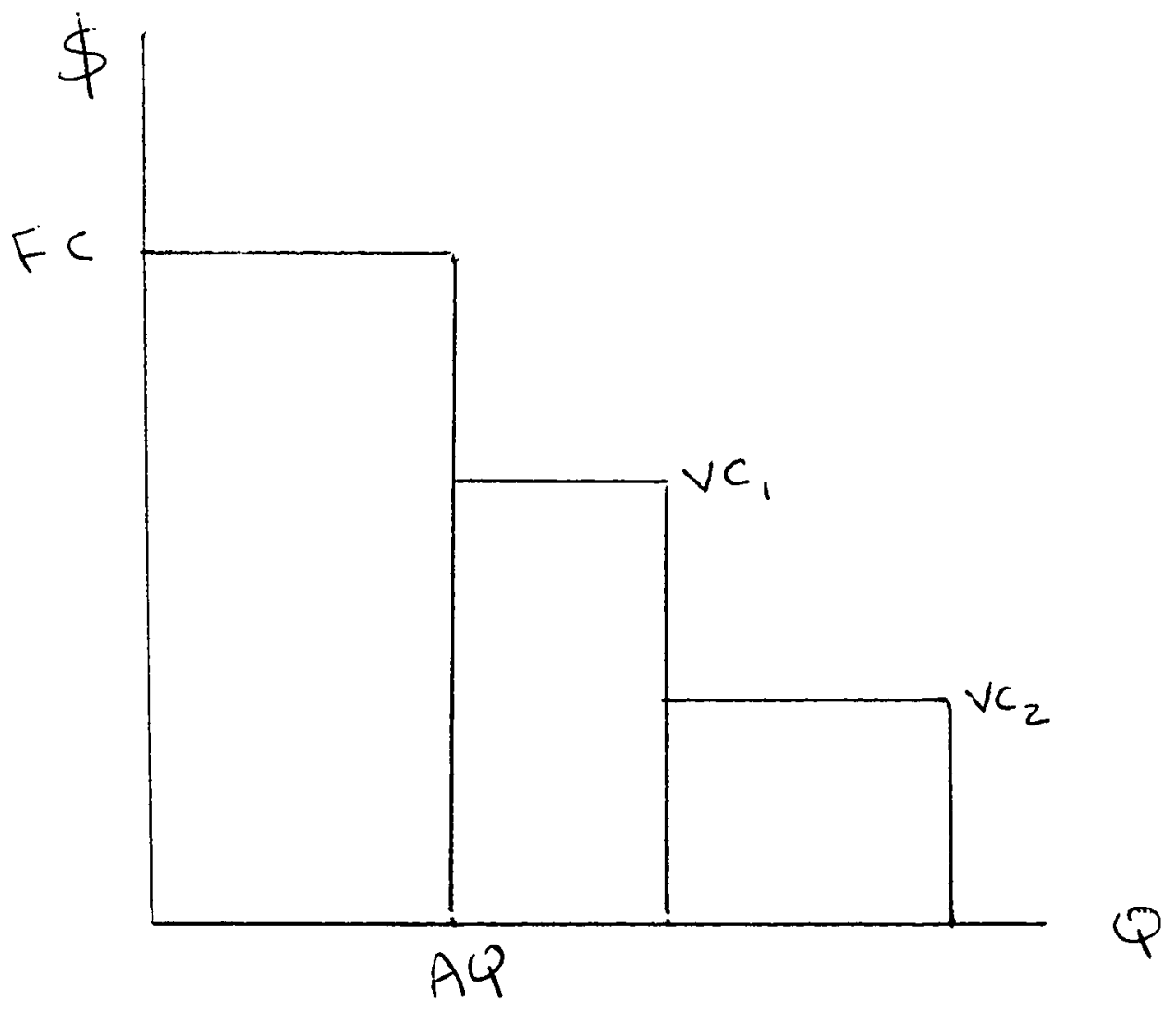

Figure 13. Declining block rate. 
demand. This leads to overinvestment in fixed assets, and recovering the total cost is the main objective of price setting.

The ideal water rate is one that is:

1. Easy to administer;

2. Covers expenditures;

3. Reflects the cost of producing the last gallons; and

4. Reflects the return to society by selling the first gallons at nominal price. 


\section{CHAPTER III}

RESEARCH DESIGN

As mentioned above, the purpose of this study is to formulate a general demand model that explains the variation in municipal water use in Oregon. The approach to this objective is a research based on empirical analysis. This requires stating general hypotheses, formulations, theoretical approach, designing a procedure of collecting and analyzing data and testing the results by application or by statistical analysis. The null hypothesis behind this research is that demand for municipal water is Oregon is invariant to different socioeconomc, demographic, and geographic characteristics. If the inclusion of certain variables in the estimating equation of a demand model for municipal water in Oregon results in a significant contribution to variance then the null hypothesis is rejected. The alternative is a model that permits any water district to estimate its quantity of water demanded given its relevant explanatory variables. The accuracy of the estimation depends on the level of aggregation of the data and the size of the unit of observation. As a statistical necessity, the standard deviation of each independent variable for individual water districts would be high, because of the heterogeneity of the study area; therefore, a broader confidence inteval around the mean is necessary (see Ostle \& Mensing, 1975, p. 1972). 
The neoclassical theory of consumer demand postulates four determinants of quantity demanded: (1) price of the good, (2) prices of related goods, (3) income, and (4) tastes.

These four factors constitute the theoretical basis on which the demand function for municipal water can be represented. The price of a consumer good is the most important single factor affecting quantity demanded. Howe and Linaweaver (1976:22-23) tested the hypothesis that the quantity of water demanded does not respond to price. When empirically tested, their hypothesis was rejected at the level of $1 \%$ significance. It is hypothesized that water has no close substitutes and, therefore, it will not be affected by prices of other goods. But there are complementary uses of durable appliances, such as washing machines. However, durable goods depreciate over a long period of time, and their prices will not affect water use. The type of these appliances may affect water use, but water conserving models are assumed to be chosen to reduce water heating costs. Therefore, the effect of the type may be ignored. Complementary nondurable goods such as food are necessary; quantities of these goods do not change very much with the changes in their prices; their demand is inelastic and, therefore, their prices do not affect water use. Thus, all cross price effect is assumed negligible, and only the price of water will be included in the model.

The above assumptions are part of the general hypothesis which explicitly states that simple extrapolation of population and past water use involves misplacement of economic resources. An alternative way of predicting water use in different jurisdictions of urban areas is possible and preferable. The alternative way requires inclusion of 
specified variables such as price and population density in an estimating equation.

\section{MUNICIPAL WATER USE IN OREGON}

The development of the public water systems in Oregon grew slowly from individual wells, collective wells or small impoundments. Wells serving individual homes or neighborhoods were adequate as a water system. They served the purpose of supplying water to communities with minimum need of refinement. Small impoundments of surface water and individual wells served the farm communities and suburban populations.

When farm and dispersed populations became urbanized, public water systems became a compelling need. Large scale development, shopping centers, industrial buildings and extensive networks of paved streets and sidewalks increased the need for water within a relatively small area.

Oregon has about one thousand water systems, about three hundred and fifty of these are public municipal water districts.

\section{Study Area}

The wide variation in physiography, geography, and climate makes Oregon a suitable study area of municipal water use in order to build a general demand model based on heterogenous regional differences.

The terrain in Oregon ranges from beautiful, undeveloped beaches and rocky coastline, to high mountain ranges with many valleys, as well as high desert plateaus. 
The climate is continental, except west of the Cascades, which is relatively warm and humid as a result of the maritime influence.

Annual precipitation exceeds 200 inches at the crest of the Coast Range. It decreases to about 35 inches in the Willamette Trough. It rises again to 100 inches or more toward the crest of the Cascade Range before it decreases rapidly to 10 inches or less in the valleys and plateaus east of the Cascade Range. Most of the precipitation comes in late fall, winter, and early spring in the central and eastern parts of the state.

Distance from the ocean, precipitation, and elevation are three factors that result in a two-season, humid, marine climate west of the Cascade Range and a four-season, dry, cold, and hot climate in the central and eastern areas. The scarcity of rainfall in July, August, and September makes irrigation an important factor for agricultural production. The growing season varies from less than 80 days to 300 days per year, making a wide range of crops possible (Columbia North Pacific Region, 1972, Appx. 16, p. 349).

The population of Oregon is about 2.5 million people, concentrated in the Willamette Lowland, the Columbia Plateau, and the Snake River Plain. More than 70 percent of the population reside in the Willamette Valley where the three largest cities--Portland, Eugene and Salem--are located.

The economy of Oregon is resource oriented. The majority of the people are directly involved in producing, harvesting, or processing forest and agricultural products or providing goods and services related to these activities. 
The products include lumber and wood products, food and binder products. Paper and allied products constitute the major classes of manufacturing activity.

There is a growing trend toward service and "footloose" manufacturing industries. The nation's only producer of nickle is located at Riddle, near the coast (Columbia-North Pacific Region, 1972, Appx. 11, p.7).

Municipal Water Supply

Water resources development in Oregon has been primarily for irrigation. But reservoirs on the Columbia and Willamette provide space for flood control and water for navigation and other purposes. More than four million kilowatts of electricity are produced at four dams in the Columbia and Willamette basins and other basins.

When it comes to municipal water, resources are available to supply municipal, industrial, and rural domestic water demands; but as municipal systems expand, ground water will not be sufficient in quantity or quality. Ground water and raw surface water must be treated before it is supplied to the communities.

Municipal water is the total need of a community less the water for major industry. The uses of municipal water include domestic, commercial, public, fire, and industrial uses.

\section{Variation in Municipal Water Supply}

In the mid-Columbia region, 66 percent of the population is served by municipal water, 84 percent in the Willamette Basin, 66 percent in the Coastal Basin, and 44 percent in the Oregon Closed Basin. From 
80 to 90 percent of the population in these regions is expected to be served by municipal water systems by the year 2020 .

The characteristics upon which municipal water consumption are based vary from one community to another. They include the size of the community, location of the community, number of commercial establishments, community habits, availability of water, quality of water, cost of water, existence of sewers, public policy (civic duties), and type and size of industry.

In a regional study of municipal water variations, the Columbia North Pacific Region considered three important variables, population, climate, and geography. According to 1970 data on the above three variables, the study came up with an average of per capita per day municipal water use ranging from 114 gallons to 213 gallons. Other studies came up with similar estimates. These estimates are reported in Columbia North Pacific Region (CNPR) Comprehensive Framework Study (1972). They were 191 gallons (Killer \& Youngwirth, 1962), 193 gallons (Westgrath, Oregon, 1952), 166 gallons (PNAWWA, 1962), 183 gallons (Porges, 1957), 166 gallons (National AWWA, 1964), and 151 gallons (Britton [Willamette], 1964).

The Columbia North Pacific Region study found greater variability in industrial requirements for water, even in the manufacturing of identical products; the amount of water use varies, depending on the process involved. Industrial water use has been computed in general terms on the basis of daily use per employee or per unit of production. 
The pulp and paper industry requires $60 \%$ of the total industrial water requirements; primary metals, $14 \%$; food processing, $8 \%$; lumber and wood products, $6 \%$. These industries have developed independent water supplies. A few food processing firms obtain water from municipal facilities.

Rural-domestic water use includes small scale irrigation, stock watering, and domestic needs. Rural populations is defined by the Columbia Northwest Pacific Region study as 250 people or less who have no connection to municipal water distribution systems. The study assumed the per capita domestic use as one-half the average municipal per capita requirement including small scale irrigation, and it is double that of livestock (Columbia North Pacific Region, Appx. 11, table 7). The stock's daily consumption is 15 gallons per head for cattle, one gallon per head for sheep, and five gallons per head for hogs, depending on the climate of the region. According to the above study, one-fourth of the population of Oregon, in 1965, was served by rural water systems. The study also projected the rate of increase of municipal water use per year to be 1.2 for the period $1960-80,1.0$ for the period 1980-2000, .8 for the period 2000-2020. The decreasing rate reflects the increase in value.

Although the above projections of municipal water requirements reflect average daily needs, water requirements can fluctuate widely depending on the type of use, season of the year, weather, and time of the day. The ratio of maximum monthly demand to the average monthly demand is 2 and the maximum daily demand to average daily demand is 2.7 (Columbia North Pacific Region, appx. 11, p. 20). 
Most of the municipalities obtain their water from surface sources. Ground water furnishes less than one-third of the total municipal requirements; however, two-thirds of the municipalities withdraw water from underground sources.

The magnitude and distribution of the future municipal water requirements can be expected to change significantly as a result of technological advances in urban living and the new scientific sociology. Increased urbanization, population growth, and increased per capita water consumption are the most important variables related to the change in water requirements.

Population growth is expected to occur in concentrated areas and cities with vast suburban fringes. As people move from city core areas to suburban communities, municipal water systems will greatly expand in size and scope of operation to extend municipal services into these areas.

There is sufficient total supply of water from abundant surface and ground water resources to meet the total requirements, but the problem is the lack of adequate facilities and sufficient capacity in existing sources at local levels to satisfy future needs at appropriate times and places.

Potential water supply problems are likely to arise in areas where ground water is the only source of municipal supplies, as in the Columbia Plateau area. In such areas, the water table is at extensive depths; aquifers are of low yield; and quality of water is poor due to excessive mineralization, high temperature, gases and objectionable taste consituents. 
Another problem is the inefficiency in water supply management. Several water districts are found in one area to serve various single interests. Consolidation of these districts and better management could result in considerable savings in water use and could permit local needs to be satisfied in the future without large expenditures for new water resources development. Consolidation and upgrading existing service districts should be part of water supply planning to get maximum returns on past and proposed investment (Columbia North Pacific Region, Appx. 11, pp. 22-23).

\section{SAMPLING PROCEDURE}

From a list of more than 1000 water districts in Oregon gathered by the Environmental Protection Agency in Seattle, 500 water districts were randomly surveyed. Surveying letters were sent in November 1983 to gather information on total quantity (TQ) of water delivered by the water district to different users; population (Pop) served by the water district; fixed charge (FC) raised by the water district; sewage charge (S) raised by the water district; variable charge (VC) raised for quantities beyond the allowed quantity; allowed quantity (AQ) associated with fixed charge; residential connections (RC) to which the water district has meters or connections; industrial connections (IC); commercial connections ( $C C)$, residential quantity ( $R Q)$; industrial quantity (IQ); and commercial quantity (CQ).

Information on other variables, income (I), temperature (T), precipitation (PR), expenditure (EX) and density (D), were gathered from the records of each county. Any water district falling in one of the 36 
counties of Oregon was assigned the value of the variables mentioned above. Information on other variables (design capacity, maximum capacity, storage capacity, average production, type of ownership, source of water and number of services) was collected from a comprehensive inventory at EPA.

The response from the water districts surveyed was good. Over $50 \%$ of them responded. The total number of water districts that included valid information on some or all of the variables was 177 . The objective is to obtain a sample of observations of municipal water districts in Oregon in regard to the hypothesized variables. A multiple regression analysis was used to obtain behavioral and structural relationships between municipal water use and the postulated explanatory variables. The main purpose of the study is to derive accurate regression coefficients of municipal water use with respect to some of the postulated explanatory variables. Another important purpose is to examine which independent variables explain the variances in municipal water use. The above objectives can be attained by constructing different submodels in the study area.

\section{VARIABLES}

It is postulated that the following variables contribute to the variation of municipal water use.

\section{Dependent Variables}

$\mathrm{TQ}=$ Total quantity of water in gallons delivered by water districts for an average month to residential, commercial and industrial 
users. This quantity is assumed to include waste resulting from negligence or leakage, since it is the quantity recorded by the water district readers each month from each connection. The data was collected in November and December 1983. Some agencies reported the most current month, others an annual amount, and others estimated an average month. GPCD = Gallons per capita per day, simply obtained by dividing TQ by 30 days and by population. This average smooths the rough measure of total quantity per month, and it is a suitable measure for perception and comparison.

$R Q=$ Residential quantity. It is the total quantity of gallons of water delivered by the district to residential connections. $I Q=$ Industrial quantity. It is the total quantity of gallons of water delivered by the water district for industrial use.

$\mathrm{CQ}=$ Commercial quantity. It is the total quantity of gallons of water delivered by the water district to commercial users such as restaurants and motels.

Many districts cannot distinguish among user types and only reported total quantity. This contributed to the reduced cases in the separate typical models.

Independent variables

Pop $=$ Total population which is served by the water district. $\mathrm{RC}=$ Residential connections. It is the total number of residential connections served by the water district.

IC = Industrial connections. It is the total number of industrial connections served by the water district.

$\mathrm{CC}=$ Commercial connections. It is the total number of commercial connections served by the water district. 
Again, many districts cannot distinguish among user connections. $\mathrm{AQ}=\mathrm{Allowed}$ quantity. It is the total gallons of water allowed with the fixed charge.

FC $=$ Fixed charge. It is a fixed amount of money in dollars billed to users each billing period to cover the line of service, connection, and meter. In some districts, this amount includes sewage charges. $S$ = Sewage charge. It is a fixed amount of money in dollars billed each billing period as service charges to cover sewer connections. $\mathrm{VC}=$ Variable charge. It is a price in dollars per 1000 gallons of water in excess of the allowed quantity. Some water districts reported this price in dollars per cubic foot. Sixteen water districts reported block rate schedules. Average VC of the multirate was considered to be the average $\mathrm{VC}$ of the multi blocks. In most cases the marginal price is a declining rate per block.

$\mathrm{T}=$ Temperature. It is the average temperature per year of the county in which the district is located.

$P R=$ Precipitation. It is the average precipitation in inches per year in the county in which the water district is located.

MRP = Precipitation per month. It is the average precipitation per year divided by 12 months.

Tax It is the property tax in the county in which the water district is located.

$I=$ Income. It is the per capita income in the county in which the water district is located.

EX = Expenditure. It is the per capita expenditure by the county on public works. In some districts this expenditure covers waterworks. 
PD = Persons density. It is the total population divided by residential connections as they have been reported by the water district.

$$
\text { HYPOTHESIZED EQUATIONS }
$$

The most important variable to be included in the equation is price. Price of water is a composite of different charges. Most districts charge a fixed charge per bill to cover the expenses of the line and the meter. Some water districts allow a certain quantity of water with the fixed charge. This quantity ranges from 300 gallons to 12000 gallons.

Most of the water districts surveyed administer sewer connections and charge for this service. They include separate charges in the bill, and it is a fixed amount.

The bill includes a variable charge after the allowed quantity. Most districts have one block after the allowed quantity in which they charge a variable charge ranging from 30 c to $\$ 2$ per 1000 gallons.

Sixteen water districts have multiple block rates. It is a declining rate.

The monthly bill is computed as follows:

$$
M B=F C+V C *(T Q-A Q) .
$$

The monthly bill consists of the fixed charge and the sewage charge if specified; then the variable charge is multiplied by quantity delivered to the customers, subtracting the allowed quantity. This monthly bill is calculated for all water districts which have variable rates after the allowed quantity. 
If average quantity is less than $A Q$, then $V C=0$. In this way, the problem of simultaneity created by different declining block rates is overcome (see Taylor, 1975).

Income is included in the study in conformity with the consumer behavior theory. Many previous studies have included proxies for income, such as home value, lawn area, number of bathrooms, etc., as explanatory variabies in lieu of or in addition to income.

Since all the above variables are interrelated, per capita income is included in this study as an explanatory variable to avoid multicolinearity.

Weather has an influence on municipal water use where horticulture is found. When there are shortfalls of rainfall, consumers apply supplemental water for grass, shrubs, etc. As far as rainfall is concerned, Oregon has two distinct regions. The coastal region has an average rainfall of 200 inches per year; the mountain region has an average of 8 inches per year. It is expected that rainfall contributes to the variance among regions in Oregon.

Temperature is another factor that contributes to variance in municipal water use from one region to another in Oregon. It is expected that the increase in temperature leads to an increase in water use; the opposite effect from that of rainfall.

CONDITIONS OF APPLYING REGRESSION ANALYSIS

In this analysis, four important coefficients need to be examined in order to arrive at an objective conclusion based on quantitative analysis. Multiple correlation ( $R$ ) gives a summary measure of the total 
variance accounted for by the linear or curvilinear relation; the partial correlation ( $r$ ) coefficients indicate the proportion of variance explained by each independent variable after the other independent variables have accounted for their share of the explanation; the $f-$ statistic indicates the significance of the regression as a whole; and the standard error (SE) from the regression plane. $R, r$ and $S E$ are sensitive to changes in the standard deviation of the independent variables, since it appears in the denominator of these statistics. The statistics of the sample may be regarded as estimates of the corresponding parameters without qualifications, as long as the sampling is random from normal multi-variable distribution (M. Ezekiel \& K. A. Fox, Methods of Correlation and Regression Analysis: Linear and Curvilinear, [New York: Wiley, 1959], Pp. 279-281; and K. A. Fost, Intermediate Economic Statistics [New York: Wiley, 1968], p. 185). The assumption of normality in the parent populations may be relaxed (M. A. Kenda11, "Regression, Structure, and Functional Relationship, Part I," Biometrika, 28 (1951) 111-25).

If the randomness is violated, stratification and selection is inevitable. This is essential if the purpose is to obtain accurate regression coefficients and to examine the predictive value of a predictive variable such as price or persons density, relevant to policy and management. This point is detailed by Fox as follows:

If we are interested in obtaining quite accurate estimates of regression coefficients, and if it is possible to subject the independent variable to experimental control, one can obtain small standard errors with a modest number of observations provided that the observations are thinly spread out over a wide range. Under such conditions and supposing there also exists 
a natural population of values of the independent variable from which we could sample at random, the random sample will inevitably provide us with a large number of values relatively close to the mean and contributing relatively little to the standard deviation of the independent variable.

Random sampling when controlled experimentation is possible is quite inefficient in terms of information gleaned per observation. If the observation can be obtained by both random and controlled experimental methods, the designed experiment should be used (Fox, Intermedicate Economic Statistics, p. 223).

The regression analysis applied to this study is based on the method devised in the Statistical Package for the Social Sciences (SPSS), Releases 7-9. The tested coefficients of the variables are listed in Table 2. The rest of the coefficients such as $r, r^{2}$ are listed in the equations table in the appendix. 
CHAPTER IV

\section{ANALYSIS}

After exploring the possible outcomes of the relationships of the different variables and according to the theory in the last chapter, we will analyze the empirical outcomes of the results. This requires composing different relationships in the form of models. Each relationship is analyzed and tested statistically according to the quantitative analysis methods and criterion coefficients known to be critical in testing. A ttest has been performed on the value of the coefficients of the variables.

The most important coefficients which provide an objective and quantitative analysis are: Multiple $R$, which shows the direction and the magnitude of the total correlation of the independent variables with the criterion or the dependent variables; partial $r$ which shows the direction and correlation of each independent variable with the criterion variable; $\mathrm{R}^{2}$ which shows the total magnitude of the variance in the criterion variable contributed by the independent variables; $r^{2}$ which shows the partial variance contributed by each independent variable; f-ratio which shows the proportion of the explained variance explained by the regression of the estimating equation or the model; f significance which shows the proportion of how many similar models are wrong in one hundred models given the number of the cases, the value of the coefficients to be estimated, $B$, or its standardized value Beta, and the standard errors from the equation (see Table 2 for significance of t-test for the coefficients and the significance of $\mathrm{f}$-value, also refer to corresponding details in the appendix). 
Since the magnitude of the regression coefficients cannot be specified on a priori considerations, a functional form is assumed. The first step in the process is specifying the variables that are hypothesized to enter the equation. These variables have been specified and defined in Chapter III. However, since the independent variable price is a composite variable, its definition needs some elaboration.

\section{AVERAGE PRICE}

There is no uniform price for water. Each water district establishes its own formula to charge for water. Taking this fact into consideration, when we collected the data, we requested reporting the different parts that comprise price.

Four important components comprise the price. These components are: allowed quantity (AQ), fixed charge (FC), sewage charge (S), and variable charge (VC). Most of the water districts surveyed base their price on these four factors.

For analysis purposes, an average price should be estimated to be included in the equation. Some water districts, however, charge a fixed charge and a sewage charge with a certain allowed quantity of water. They charge one rate for the excess quantity regardless of the variation in that quantity. These water districts differ from those which charge a flat rate for all use or charge a declining rate or increasing rate for subsequent blocks of water use. For all the above differences, arriving at a uniform average price requires the following manipulation to arrive at a monthly bill (MB). 
Each water district sends a monthly bill to individual user, $i$. This monthly bill is calculated as follows:

$$
\mathrm{MB}_{i}=\left(\mathrm{Q}_{\mathrm{i}}-\mathrm{AQ}\right) * \mathrm{VC}+\mathrm{FC}+\mathrm{S}
$$

Since individual users are not the unit of observation in this analysis, a system with average price is calculated for total consumption, as well as for all residential users, all commercial users, and for all industrial users. The average price, $P_{j}$, that faces these user groups, $j$, is defined by $M B_{j} /\left(Q_{j} / 1000\right)$. In this way $P_{j}$ can enter the equation as representative of the four factors that compose the price.

A correction for the water districts that charge a variable charge on declining or increasing block rate was required. This has been done by establishing the average variable charge. Seven water districts were treated in this way.

The allowed quantity ranges from 400 gallons per month per connection to 12,000 gallons in a month's billing period. Sewage charge may be handled by a separate sewage district, but none of these water districts in our sample falls in this category. The fixed charge is associated with the service connection and the allowed quantity.

The commodity price is the variable charge. But since the variable charge is associated with water use beyond the allowed quantity, its effect will be great if the allowed quantity is small.

Since the users will exceed the small allowed quantity, the variable charge will be high with small allowed quantity and the fixed charge will be small. When the allowed quantity is high, the effect of the variable charge is minimal since the users are able to curtail their excess use beyond the allowed quantity if the variable charge is high. Therefore, 
the effect of VC will be zero if the allowed quantity is very high. The fixed charge, however, should be high with or without the sewage charge. Small users benefit from high allowed quantity and low variable charge but big users get penalized by small allowed quantity and high variable charge. However, small users with high allowed quantity and low variable charge bear a high fixed charge and/or sewage charge.

In the water districts that charge the variable charge on declining block basis of water consumption, price is a declining function of quantity demanded. In other words, the quantity of water consumed determines the price to be charged $(V C=f[Q])$, rather than $(Q=f[P])$ as the consumer behavior theory suggests. It is appropriate to eliminate those water districts from the sample or to find an average uniform price as we did with seven of the water districts.

The variable charge has been the choice of many previous studies as the actual price paid for the quantity delivered. These studies assumed that it will reflect the marginal price which is consistent with the premises of the theory of efficiency and equity.

In this study, considering the variable charge only would exclude the districts that do not meter the water or charge a flat rate and send a bill only two times a year (a winter bill and summer bill). Also, some water districts have block rates for the variable charge and this involves calculating the variable charge for each use for each block. This information is not available because it requires recording the quantity of each user and the quantity of each block. Many water districts gave the average price for the blocks. 
For the above considerations, average price, as we have calculated above, is superior, although it lacks the premises of equity and efficiency of the economic theory. Moreover, average price is easier to use as an administrative tool to collect the necessary revenues to cover the expenditure on the water facilities as they are allocated by the authority of the water districts.

Due to the above considerations, average price is considered to be the price of water consumed for each user group $j$ and is calculated in the following manner:

$$
\left.P_{j}=M B_{j} / Q_{j} / 1000\right)
$$

where $M B$ is the monthly bill, as it has been specified above.

It is expected that quantity of water is a declining function of average price reflecting the effect of marginal price.

The consumer theoretically is sensitive to marginal charge, but not in the case of water where the effect of VC is included and reflected in the average price. Marginal price VC, by itself, has no effect or its relation with the quantity of water is a spurious one as it has been explained above, when we have water districts with declining block rates. It is clear that the quantity of water beyond essential use should be the function of VC reflected in the average price. The behavior of the consumer is a function of the fixed charge and the sewage charge for the total use. In other words, the size of the bill with its major components FC and $S$ affect the consumption, especially if the use does not exceed essential use and the variable charge is based on declining block rating. 
It is expected that the water use is a linear function of the number of persons in the residence. Other studies have estimated that each person is likely to use about 30 to 40 gallons daily for bathroom purposes on the assumption that the average toilet tank holds 4 gallons of water, the average sink about 1 gallon and about 10-20 gallons for a bath or shower.

Allowed quantity (AQ) is an amount of water allowed with the minimum bill (i.e., the fixed charge with or without the sewage charge). The average price of this allowed quantity is higher than the commodity charge (i.e., the variable charge, marginal price of water). If the variable charge was imposed right from the first unit of consumption, the consumer has an incentive to reduce water use from the first unit of consumption. It implies the abolition of the fixed charge. The policy implication is to reduce water use after the allowed quantity as an application of the equity principal for the small users of essential quantities. The allowed quantity ranges in the study area from 400 gallons per residential connection to 12,000 gallons per residential connection in the very small districts.

The effect of the allowed quantity is that water use by a household is expected to increase as the allowed quantity of water increases as Figure 14 will show. The demand curve approaches the price axis asymptotically, as indicated by a dashed 1ine, which means even at a high price, a minimum quantity of water is demanded. If the quantity $Q$ at $P_{1}$ is the consumer's utilization of water and an allowed quantity at $\mathrm{AQ}_{1}$ is included, which is less than the quantity of his total utility, the consumer would still buy $Q$. But if the allowed quantity is at $\mathrm{AQ}_{2}$, which is 
66

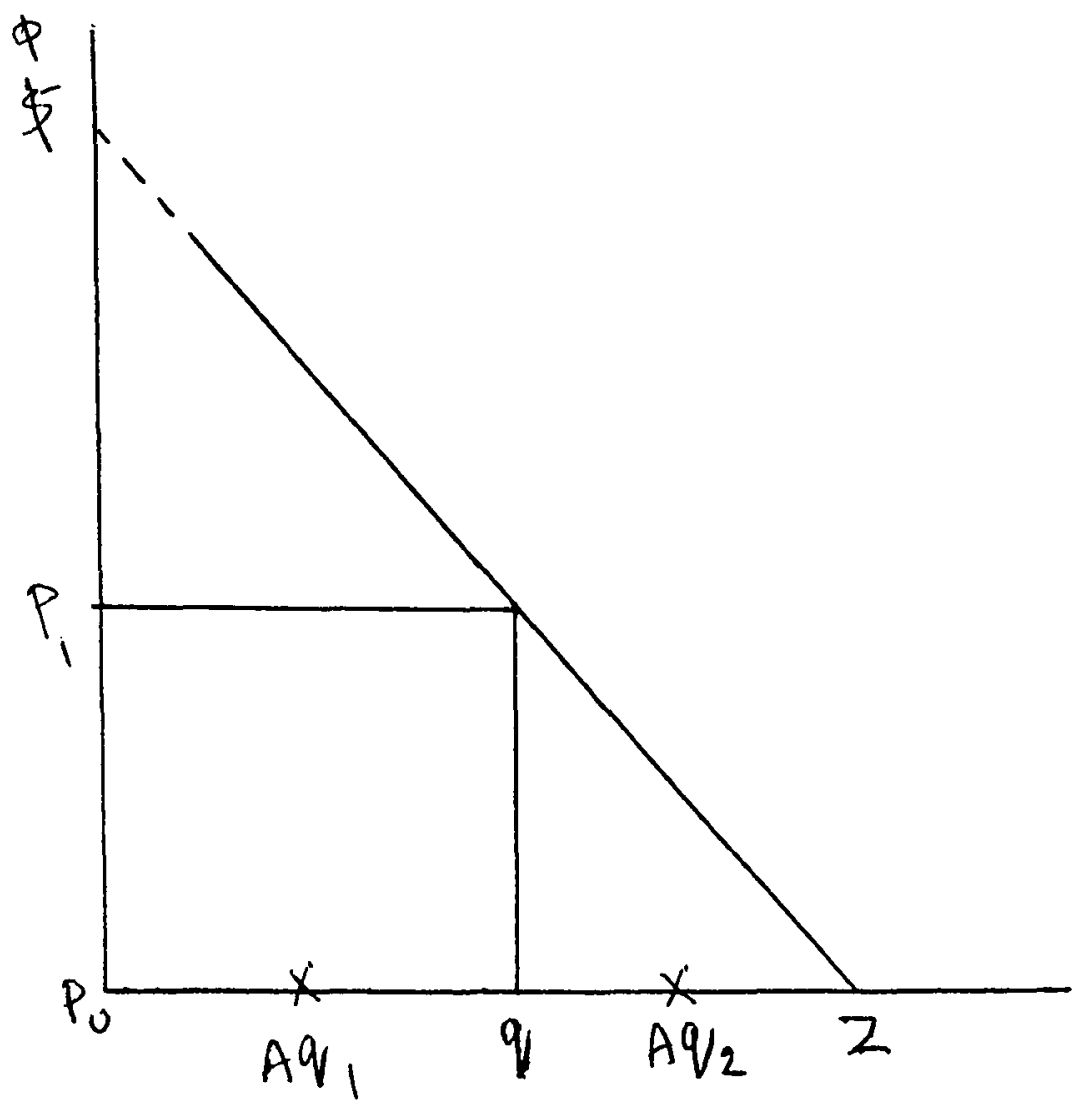

Figure 14. Effect of AQ. 
more than the total utilization at $Q$, the consumer would increase utilization towards $\mathrm{AQ}_{2}$, even if his utilization is at $Q$. The correlation between $\mathrm{AQ}$ and the quantity of water used is expected to be positive. The consumer will exceed the allowed quantity unless he is saturated at Z (Grima, 1972).

The size of the fixed charge is hypothesized to affect the amount of water used by a household. If the monthly bill is very high, some water-complementary uses would be reduced, irrespective of the components of total price which include fixed and variable charges. If the fixed charge is high, the consumer will try not to increase the bill any further, even if the variable charge is very low. Therefore, the relationship of this variable to water is expected to be negative. The fixed charge may reflect related conditions pertaining to the water district as a whole (e.g., over assessment) and may act as a dummy. The distribution of the errors should indicate whether it is acting as a dummy or not.

\section{ERRORS OF MEASUREMENT}

The errors of measurement are detected in standard error from the equation. The errors of measurements are caused by heterogeneity among water districts in recording and keeping water use records.

Some water districts read the meter once a month and others read it two times a year, resulting in an error when calculating the average usage per month. This error, however, is small relative to total quantity delivered by the water district or the quantity used by a household or an individual. These errors should be normally distributed given the 
spectrum of the data. Although the data was collected in November 1983, averaging the data per month per year is based on the observations of other months. Some water districts based the observations on the basis of the records of summer. Again, there is normal error due to averaging monthly use based on winter and summer observation.

FUNCTIONAL FORM

Linear form is assumed to be a unique functional form to fit the data. This assumption follows the tradition that demand function is linear (Turnovsky, 1969). Howe and Linaweaver, however, did not find theoretical reasons to specify a unique function. They fitted linear and multiplicative function for domestic demand and the results were comparable for both forms (Howe \& Linaweaver, 1966). Curvilinear relationships cannot be detected if the standard error from the equation is great. But if a curvilinear relationship is assumed, curvilinear form of the equation is better tested against the data.

Demand for water is expected to have a positive correlation with income. As income increases, demand for water increases in a linear manner. This might be true at first, but the linear increase (straight line) will not hold beyond some point. Some water uses may increase at a declining rate (curvilinear) with income such as car washing or personal consumption of water. Some water uses may decline with increasing rate of income. As income increases, less time is spent at home and fewer persons are living together.

The relationship between price and residential water use may be a curvilinear relationship on the basis of considering the segments of 
the demand function of the total water use by a household (Figure 15). Essential water use for drinking and cooking has an inelastic demand; the consumer is willing to pay a high price for a small quantity of water. If the price drops to zero, demand is still small. Demand for less essential use decreases with price with greater elasticity. The total demand curve must be curvilinear (Grima, 1972) (Figure 15).

The null hypothesis is that water use is invariant to price. It is rejected if the coefficient of price is significant (see Table 2 for the significance of the T-test and multiple regression appendix). If, on the other hand, the coefficient of price is equal to zero or not different from zero, the null hypothesis cannot be rejected. However, if the null hypothesis was not rejected, curvilinear relationship may be hypothesized on the assumption that at low price the less essential water uses and the demand function are responsive to price change at that segment. When price is raised, the least essential water use can be curtailed. When price is high, the demand function at the essential use is relatively irresponsive to price change and the essential demand will not be reduced. Therefore, in a water district where the price is high, any price change will have low effect on water use in absolute terms because there is no luxury watcr use. But in a water district where price is low, the effect of price change is greater because there will be luxury use which could be curtailed. We may reverse the argument and say that water districts which provide water for essential use only (small water districts) have high prices and large water districts can provide water for luxury and have low prices. 


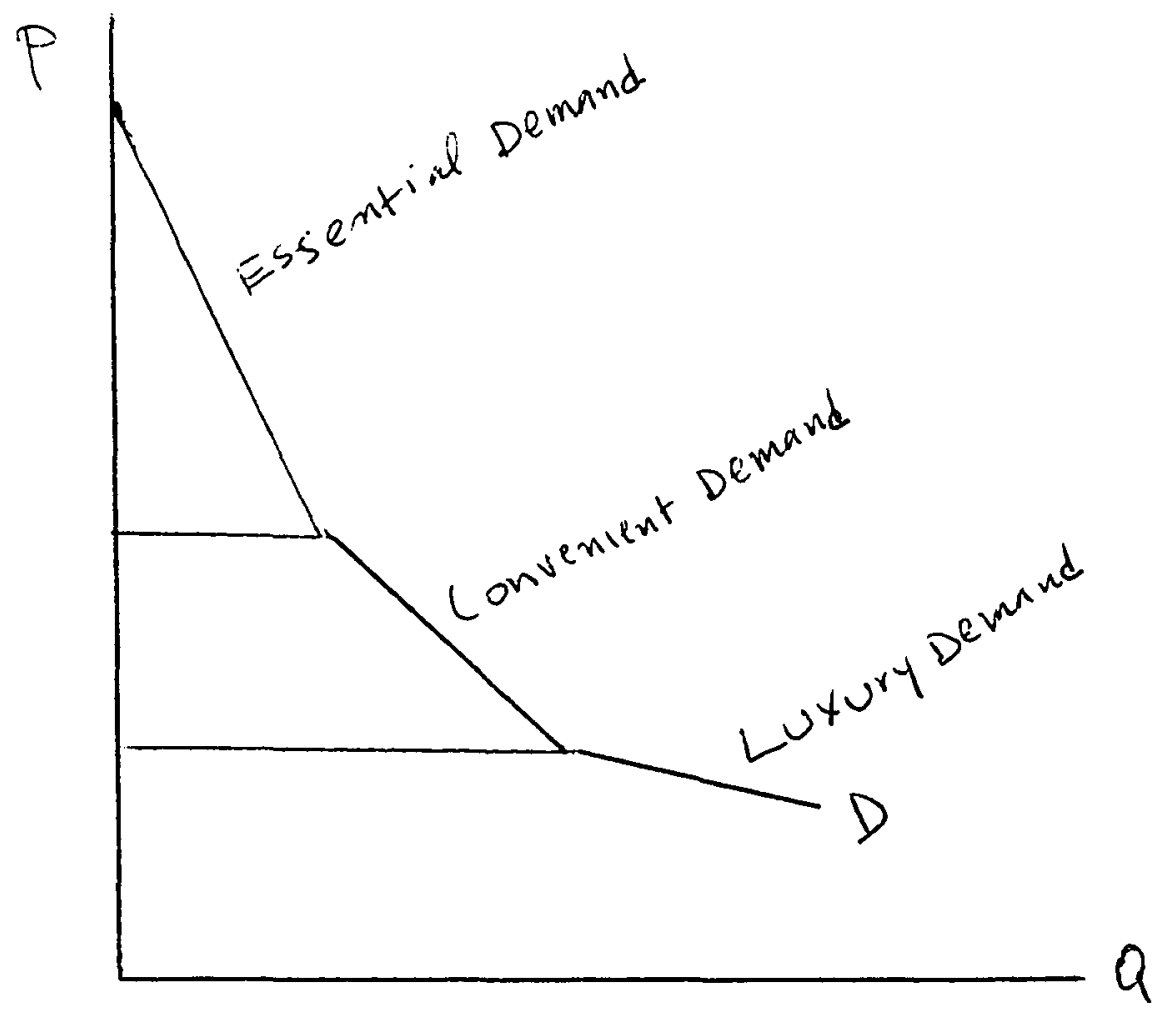

Figure 15. Segments of water use. 
EMPIRICAL EVALUATION

The first step in the empirical process is to include all the aforementioned and hypothesized variables in a functional form. The process consists of four steps: selecting the models, analyzing the models, testing the models, interpreting them and stating the conclusion.

Selecting the models is the first step in the empirical evaluation and is essential in the quantitative analysis. The selection is based on the general hypothesis that the quantity of water demanded by different users and delivered by the water districts in the study area is affected by certain hypothesized independent variables which have been specified above. This general hypothesis can be stated in the conventional form. The quantity of water used is invariant to the specified variables. This hypothesis is rejected if we find a significant variance attributed to any hypothesized and specified independent variables. The variance is expressed by the magnitude of the coefficient of the hypothesized independent variable. If, on the other hand, we find the magnitude of the coefficient is zero or not significantly different from zero, we can accept the general hypothesis that water use is invariant with the hypothesized and specified independent variables. For more information about the different values corresponding to the independent variables such as the significance of f-value change (see multiple regression appendix).

On the above bases, we chose to fit the collected data to four models: a generai model, a residential mode1, a commercial mode1, and an industrial model.

The general model has its dependent variable, the total quantity of water, TQ, delivered by the water districts to different users; 
TQ has been specified above and collected separately from the different water districts included in the study area. Numerous equations were experimented with, including all independent variables. The best equations that included the variables which met the accepted level of significance are presented here. The level of significance upon which we accept or reject the whole estimating equation is represented by $f$-value and its significance.

The residential model has its dependent variable, the residential quantity, RQ, as a partiuclar use of water delivered to residential connections. Again, in this model, several equations have been experimented with with the hypothesized independent variables that might have an effect on residential water use. The best equations that explain the variation in the residential water use with the expelled and hypothesized variables are considered the estimating equations, which cannot be rejected because the criterion of rejection has not been met, namely the coefficient of the variable and f-value, and the proportion of the variance explained by the equation is significantly different from zero.

The commercial model has its dependent variable, the commercial quantity, $C Q$, delivered by water districts to the commercial enterprises. The data on this particular use has been requested apart from general use of other particular uses. The equations in this model are subject to the same scrutiny of testing applicable to the first two models.

The industrial use model has its dependent variable, the industrial quantity, IQ, as specified in the definitions of the variables above. 
EQUATIONS OF THE GENERAL MODEL

Equation (1)

$\mathrm{GPCDT}=(\mathrm{TQ} / 30) / \mathrm{Pop}$, dependent variable

$\mathrm{PT}=$ Average price. $\mathrm{PT}$ is calculated according to the following formula:

$$
\begin{gathered}
\mathrm{PT}=\mathrm{MBT} /[(\mathrm{TQ} / 1000) / \mathrm{Pop} / \mathrm{HH}] \\
\text { where: } \mathrm{MBT}=[\mathrm{T} ? / 1000 /(\mathrm{Pop} / \mathrm{HH})-(\mathrm{AQ} / 1000)]^{*} \mathrm{VC}+\mathrm{FC}
\end{gathered}
$$

$\mathrm{PT}$, the average price, is specified above in relation to the MBT, the monthly bill of the total quantity to arrive at a uniform price by the end user. This point has been elaborated in Chapter II under the topic "Existing Practice of Price Structure" and in Chapter IV under the topic,"Average Price."

Two conditions have to be fulfilled to satisfy the above specifications: (1) When the water district does not have a variable charge, the monthly bill, MBT is equal to the fixed charge, FC; in this case, the average price, $\mathrm{PT}=\mathrm{FC} /(\mathrm{AQ} / 1000)$. This average price is practiced by the water districts which allow water with the fixed charge and consider $A Q$ as the average use per connection. This assumption might be the case of the small water districts which envisage the elmination of the administrative cost of installing and reading meters and charging a variabie charge. Fixed charge is easier to administer, especially in the small water districts where the effect of economies of scale do not play a role of reducing the costs of producing the water and where inflation adds to the costs. (2) When there is no allowed quantity, AQ, the average price, PT does not reflect a monthly bill, MBT, which subtracts the allowed quantity. 
$I=$ Income

Weather $=$ Temperature/precipitation

$\mathrm{DAQ}=$ Dummy of allowed quantity, $\mathrm{AQ}$

DS = Dummy of sewage charge.

In order to read the elasticity directly from the coefficient, the natural $\log$ of GPCDT, PT, I were calculated before entering them into the equation.

$\log$ GPCDT $=2.97-.64 \log$ PT $+.21 \log I-0.000638$ weather
S.E.
$(.07)$
$(.37)$
$(.002)$

T-Value

$-9.05 * * *$

.56

$-.31$

$$
+.02 \mathrm{DAQ}+.01 \mathrm{DS}
$$

S.E.

T-Value

.20

.11

$* * *$ Significant at .01

$* *$ Significant at .05

*Significant at .10

$$
\begin{aligned}
& N=156 \\
& R=.61 \\
& F-\text { Value }=18.24 * * *
\end{aligned}
$$$$
\bar{Y}=4.81
$$$$
s_{y}=.68
$$$$
\mathrm{R}^{2}=.37
$$$$
\text { S.E. }=.54
$$

In the above equation, the sign of the variables, hypothesized to have effect on the total quantity of water as specified in the equation above, is the right sign. From this equation, the hypothesis that the total water use is explainable by the above dependent variables cannot be rejected. The only significant variable, however, is the average price. No other variable included in the equation explained significantly 
the variation in the total water use. It has been hypothesized, however, that weather and income contribute to the variation.

A possible explanation of the nonsignficant affect of weather and income is due to the nature of the dependent variable. It includes residential, commercial and industrial use. The residential use must be responsive to the average price and weather. When average price is high, average residential use of water is expected to drop. This result, however, is not necessarily applicable to commercial and industrial use. Some commercial and industrial uses cannot be reduced or increased due to the change in average price. This is reflected in the small magnitude of $\mathrm{R}^{2}$ in the equation which explains $37 \%$ of the variance although the variables correlate with the total quantity, $61 \%$.

Weather is expected to explain much of the variance in residential use, but may not explain variation in total use.

Income on the other hand must reflect some significance, but it did not, probably because of the rough measurement. Per capita income in counties may be a poor proxy for per capita income for water districts contained therein. This relationship would probably require analysis using household level data.

The elasticity of average price is -.64 , reflecting the average use of water with the three major components, residential, commercial, and industrial.

Equation (2)

GPCDT $=[(R Q+C Q) / 30] /$ Pop, dependent variable. Industrial use is idiosyncratic and is not subject to explanation by the same variables as the residential and commercial uses. We excluded 
from the equation those water districts which did not report residential quantity, RQ; commercial quantity, CQ; variable charge, VC; fixed charge, FC. The criterion of exclusion limited the number of the water districts to 31 cases. Variables used are:

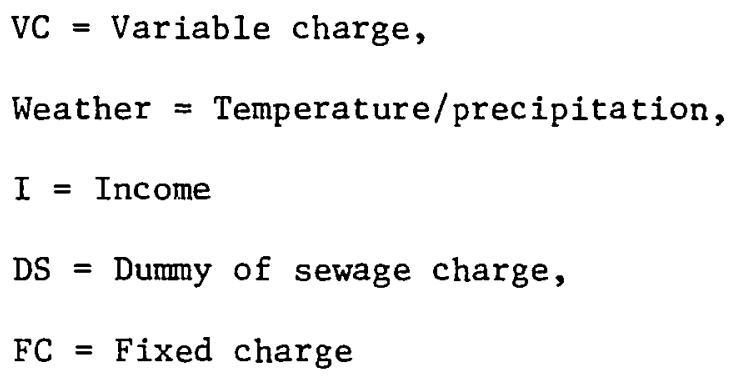

Log GPCDT $=2.41-.61$ Log VC +.01 Weather -.13 DS +.21 Log I -.03 Log FC

$\begin{array}{lllllll}\text { S.E. } & (.13) & (.004) & (.17) & (.50) & (.20)\end{array}$

$\begin{array}{llllll}\text { T-Value } & -4.65 * * * & 2.99 * * * & -.77 & .41 & -.16\end{array}$

$\mathrm{N}=31$

$\overline{\mathrm{Y}}=4.75$

$\mathrm{S}_{\mathrm{y}}=.58$

$\mathrm{R}=.75$

$\mathrm{F}-$ Value $=6.55 * * *$

$\mathrm{R}^{2}=.56 \quad$ S.E. $=.42$

The results of this equation confirm the findings of the first equation which included the average price, PT. The uses that are likely to be responsive to the variable charge and weather are the residential and commercial. Commercial, however, is expected to be more responsive to variable charge, while residential use is expected to be more responsive to changes in climate, especially if the residential use is for essential purposes in the household, and especially if the water district works on a small scale where the effect of economies of scale in the production of water is absent. 
The elasticity of the variable charge is -.61 and the elasticity of income is .21. Income elasticity is reported here for the purpose of comparisons with other studies not for the purpose of estimation since income was not a significant variable in this equation.

\section{RESIDENTIAL MODELS}

\section{Equation (1)}

In this equation we are testing the average price, RP as it has been specified below:

$$
\mathrm{RP}=\frac{[(\mathrm{RQ} / 1000) / \mathrm{RC})-\mathrm{AQ} / 1000] * \mathrm{VC}+\mathrm{FC}}{[(\mathrm{RQ} / 1000) / \mathrm{RC}]}
$$

If the water district has only fixed charge, $\mathrm{RP}=\mathrm{FC} / \mathrm{AQ} / 1000$; when the water district does not have an allowed minimum quantity, $A Q$, $\mathrm{RP}=[(\mathrm{RQ} / 1000) / \mathrm{RC}] * \mathrm{VC}+\mathrm{FC} /[(\mathrm{RQ} / 1000) / \mathrm{RC}]$

The above specification of the average price follows the same principle followed in the calculation of the average price of the general model above. To arrive at a uniform average price, inclusion of all the factors that constitute the monthly bill associated with the average use must be included. These factors are VC, FC and AQ. GPCDR $=R Q / 30 /$ Pop, dependent variable.

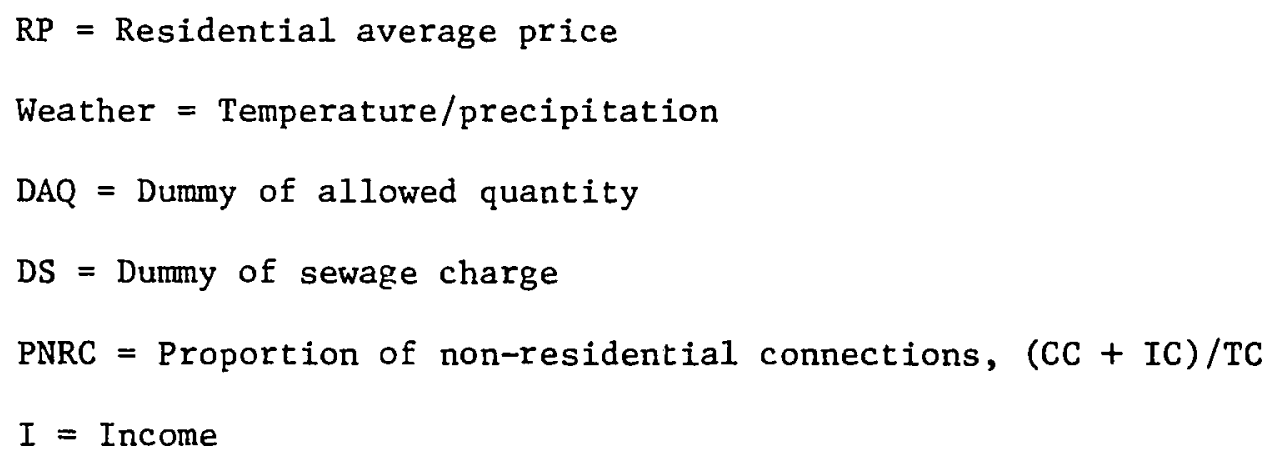




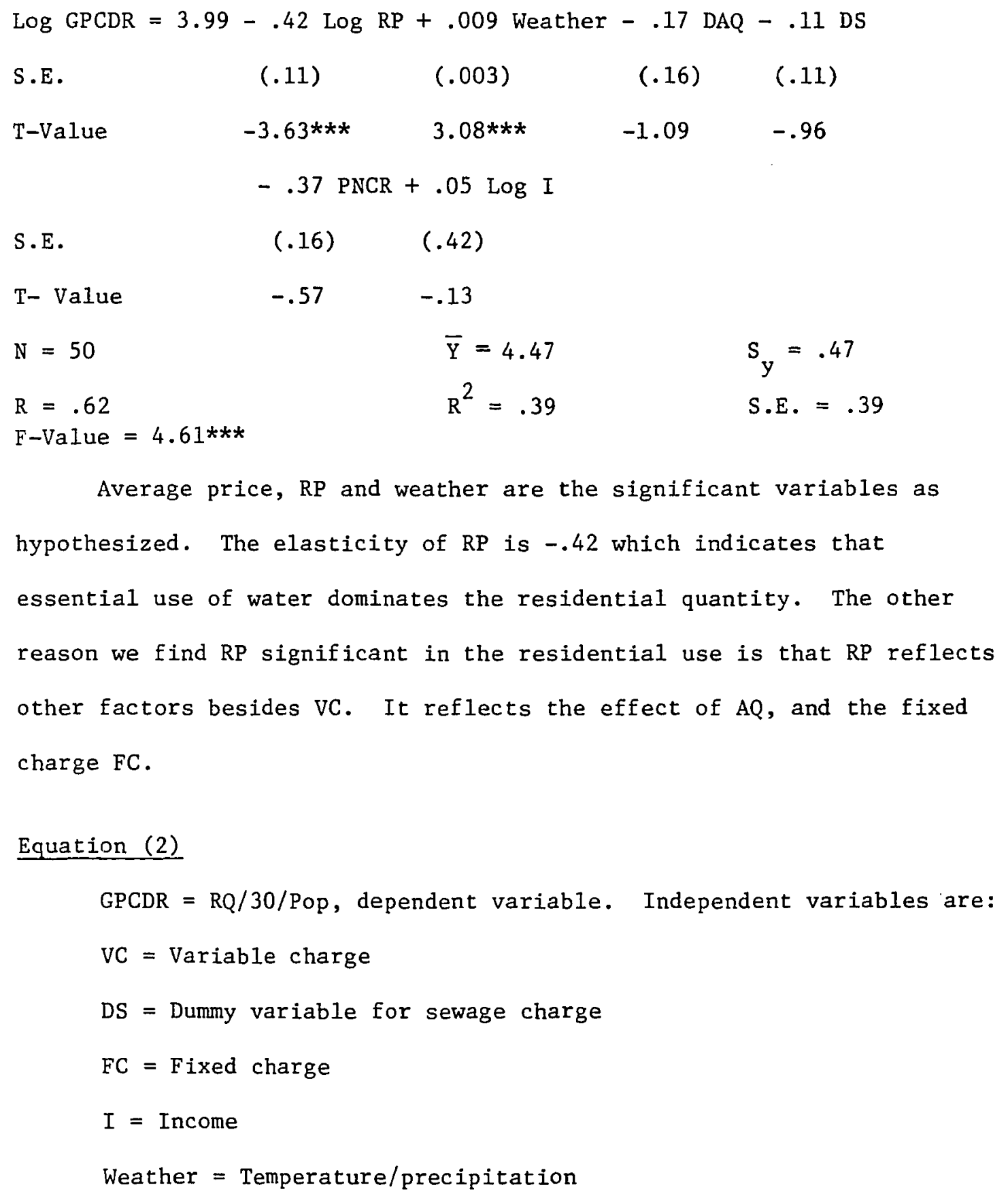


$\log \mathrm{GPCDR}=2.91+.01$ Weather $+.21 \mathrm{DS}+.16 \log \mathrm{FC}+.08 \log \mathrm{I}-.01 \mathrm{Log} \mathrm{VC}$
S.E.
$(.12)$
$(.14)$
$(.38)$
.10

T-Value

$3.94 * * *$
$1.65 *$
1.09

$.21-.19$

$\mathrm{N}=38$

$\overline{\mathrm{Y}}=4.41$

$\mathrm{S}_{\mathrm{y}}=.41$

$\mathrm{R}=.65$

$\mathrm{R}^{2}=.42$

S.E. . 33

F-Value $=4.87 * * *$

The criterion for inclusion of the variables in the above equation is that RQ, VC and FC were greater than zero. The above equation confirms the importance of climatic changes in the consumption of residential water. It confirms again that the variable charge is not a factor in the residential water use, unlike the average price which was significant in Equation (1). This fact leads to two conclusions: the water districts in the equation are small water districts which provide allowed quantity with the fixed charge large enough to cover most of the essential use in a household, and the household's response to the total bill but not to the individual components of the bill such as the VC, FC, or AQ. Beyond the essential use of residential quantity, weather is the significant variable; horticulture, lawn watering and car washing are responsive uses to weather.

NON-RESIDENTIAL USE

\section{Equation (1)}

When commercial and industrial use combined to represent the dependent variable, the variable charge remained the significant variable along with the dummy variable of sewage charge. The relationship 
somewhat indicates the importance of the variable charge, VC. Again, in this equation water districts which did not report commercial quantity, CQ; variable charge, VC; and fixed charge, FC were excluded from the equation.

$\mathrm{GPCDT}=[(\mathrm{CQ}+\mathrm{IQ}) / 30) / \mathrm{pop}]$, dependent variable. Independent variables are:

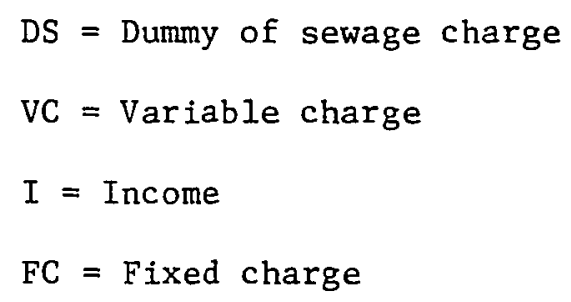

The elasticity of VC is -.98 , which is higher than the elasticity of the previous equations. The inclusion of the industrial use made the dummy of sewage charge somewhat significant.

\section{Equation (2)}

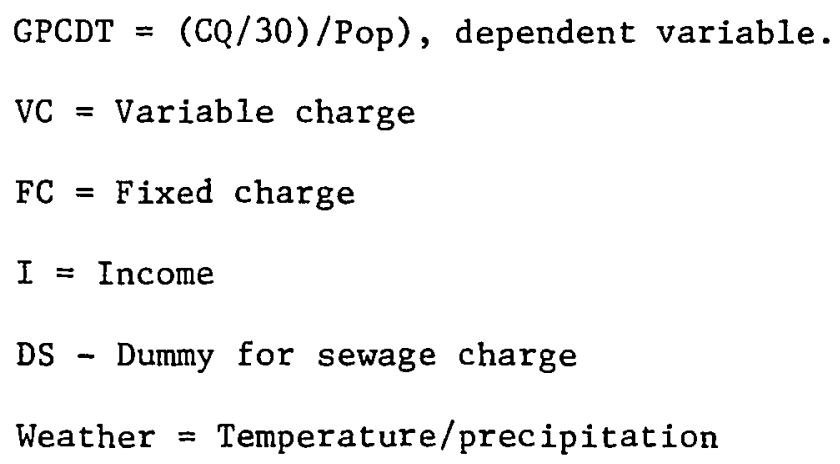


Log GPCDT $=2.89-1.31$ Log VC +.01 Weather -.13 DS +.14 Log FC -.12 Log I
S.E.
(.148)
$(.59)$
(1.43)
T-Value
$-3.47 * *$
$1.37 *$
$-.28$
.24
$-.08$
$\mathrm{N}=31$
$\overline{\mathrm{Y}}=3.14$
$\mathrm{s}_{\mathrm{y}}=1.37$
$R=.60$
$\mathrm{R}^{2}=.36$
S.E. $=1.20$
F-Value $=2.84 * *$

This equation confirms the hypothesis that commercial use is responsive to the variable charge. Variable charge has an elasticity of -1.31 which is greater than that of the elasticity of PT in the general model and the $\mathrm{RP}$ in the residential model. Commercial use is responsive to variable charge because it is a use for profit. If the variable charge is raised to a point where the profit is reduced, commercial water use is reduced significantly. Weather is somewhat significant in the commercial use but not as it is with the residential use.

\section{Equation (3)}

As it has been mentioned above, industrial use is idiosyncratic which might be explained by other variables such as the type and size of industry and rate of return. The specified variables above did not show the relationship expected. However, the fixed charge and the sewage charge are the variables that were expected to be identified with industrial use. Two equations were tested. The first one has its dependent variable, the sum of the different uses, including industrial use. The industrial use impaired the effect of the significant variables in previous models. 


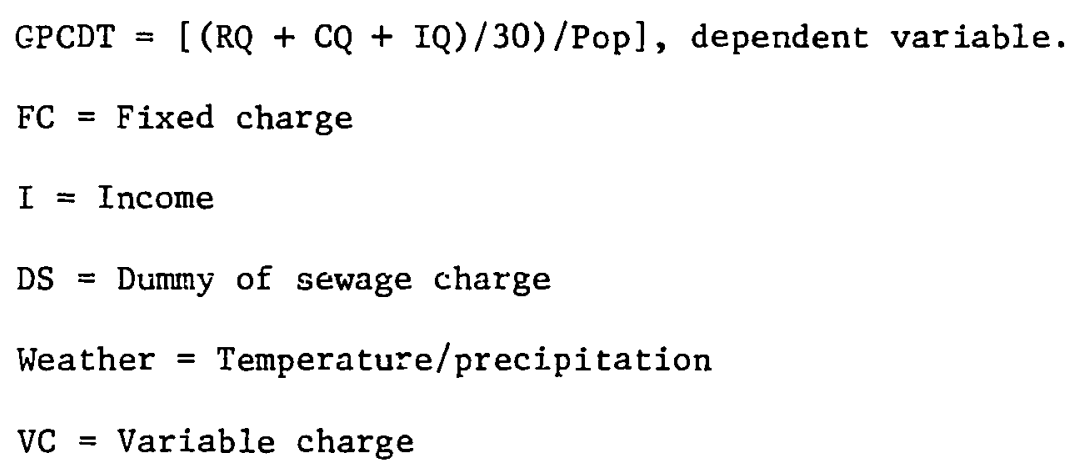

$\log$ GPCDT $=8.53-1.05 \log \mathrm{FC}+.02$ Weather $+.77 \log \mathrm{VC}+.62 \mathrm{DS}-.23 \log \mathrm{I}$

$\begin{array}{llllll}\text { S.E. } & (.70) & (.01) & (.76) & (.07)\end{array}$

$\begin{array}{llllll}\text { T-Value } & -1.48 * * & 1.16 & 1.00 & .58 & -.07\end{array}$

$\mathrm{N}=16$

$\bar{Y}=5.36$

$\mathrm{S}_{\mathrm{y}}=1.08$

$R=.64$

$\mathrm{R}^{2}=.41 \quad$ S.E. $=1.02$

F-Value $=1.39$

The criterion upon which the variables were selected is the industrial quantity, IQ. Any water district that did not report industrial quantity was eliminated from the equation; likewise VC and FC. For this reason, the number of cases was reduced to 16 water districts.

Fixed charge in the above equation was the only significant variable. None of the rest of the variables was significant due to the inclusion of the industrial use.

To confirm the point that industrial use impairs the effect of the hypothesized independent variables, we tested the equation with industrial use, IQ only as follows: 
Equation (4)

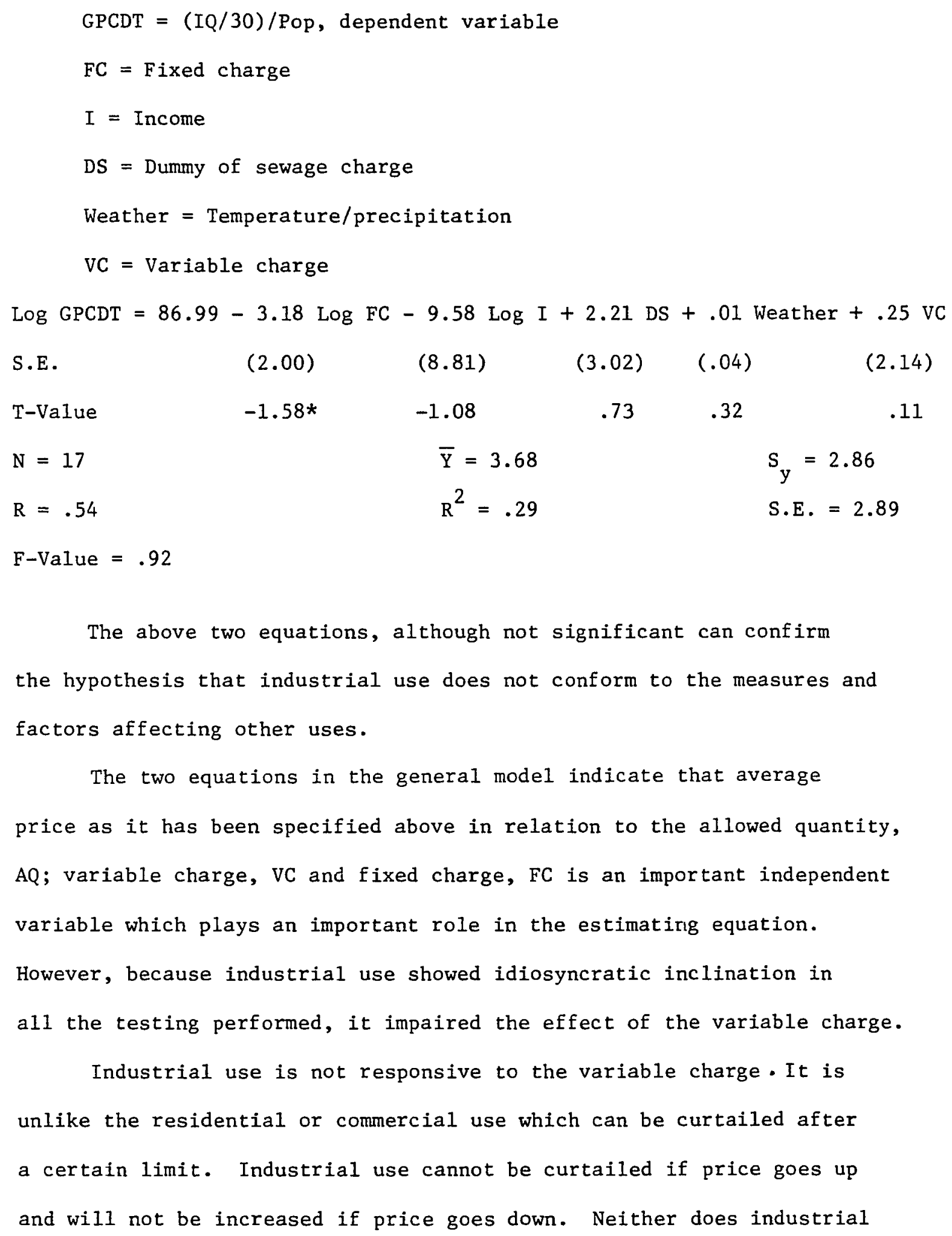

The above two equations, although not significant can confirm the hypothesis that industrial use does not conform to the measures and factors affecting other uses.

The two equations in the general model indicate that average price as it has been specified above in relation to the allowed quantity, $\mathrm{AQ}$; variable charge, $\mathrm{VC}$ and fixed charge, FC is an important independent variable which plays an important role in the estimating equation. However, because industrial use showed idiosyncratic inclination in all the testing performed, it impaired the effect of the variable charge. Industrial use is not responsive to the variable charge. It is unlike the residential or commercial use which can be curtailed after a certain limit. Industrial use cannot be curtailed if price goes up and will not be increased if price goes down. Neither does industrial 
use flucturate with weather. It is responsive to such measures as the sewage charge and fixed charge. When a water district changes the variable charge from time to time due to addition to capacity or acquiring a new source of water or when operational costs increase due to inflation or to better administrative methods such as installing special meters and repairing leakage faults, industrial use does not fluctuate as well. It is likely to remain constant for a long period of time. This explains why industrial use is more responsive to long run measures such as the fixed charge and the sewage charge. This explains why some industries develop their own water source. Table 2 is a list of the variables tested in the different models and their coefficients. 


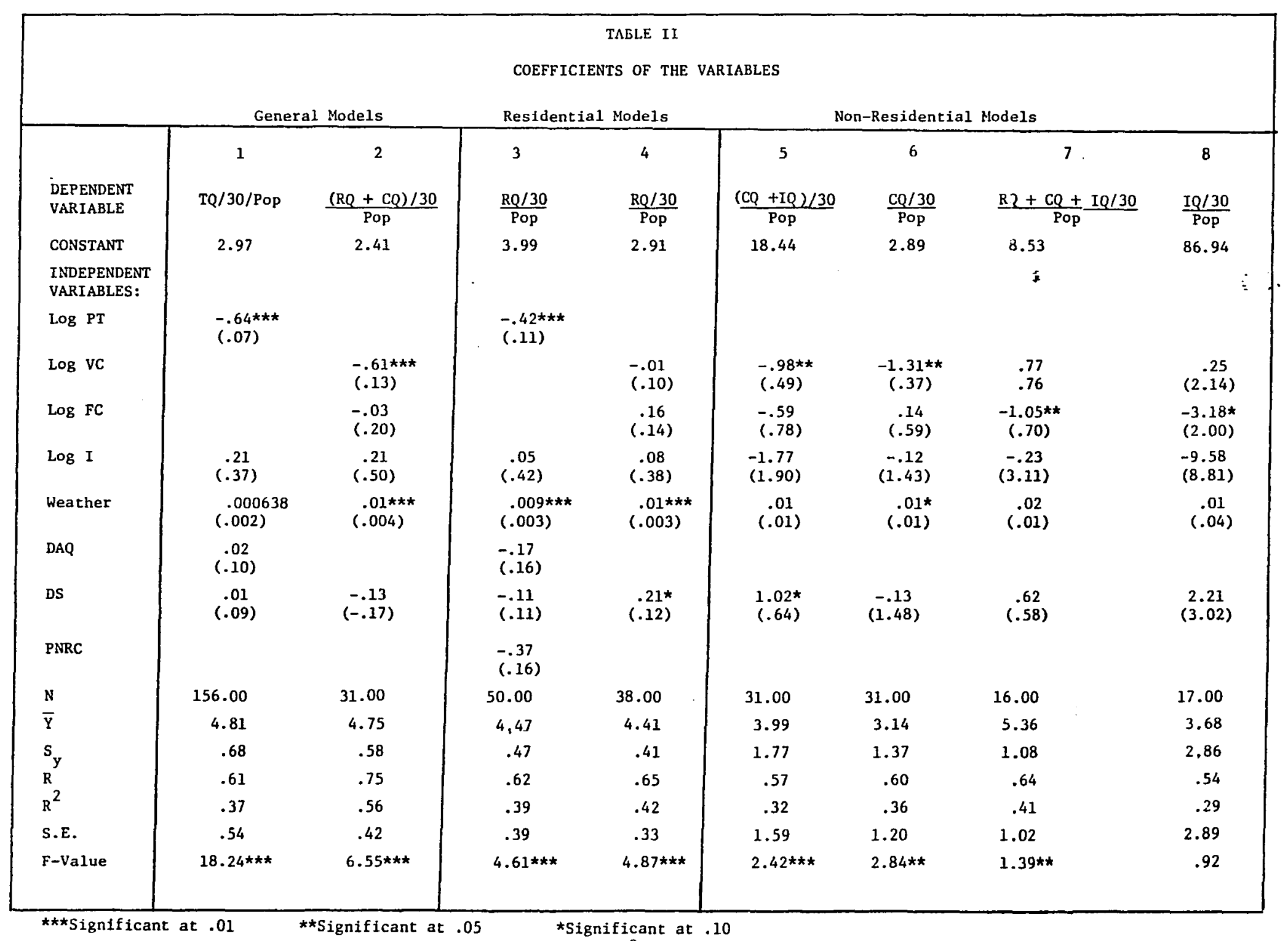

(See the significance of $f$-value change corresponding to $r$ and $r^{2}$ in the multiple regressiom table in the appendix) 


\section{CHAPTER V \\ RESULTS AND CONCLUSIONS}

FINDINGS

The results of the study are commensurate with the neoclassical theory of demand, which postulates that price of a good, prices of related goods, income and tastes determine the quantity demanded. In this context, the study established the importance of price. Average price was tested empirically and found to be effective in the general model (1) (see Table 2), where the total quantity of water delivered by the water district contained all types of uses. In this model, the price elasticity was found to be -.64 . Average price was also significant in the residential model (3) (see Table 2). The elasticity was -.42 .

Another empirical evidence of the importance and significance of price was established by testing the variable charge (VC). The variable charge was found to be significant in the general model (2) (see Table 2). The elasticity was -.61 . The elasticity became -.98 , in model (5) (see Table 2) and -1.31 with commercial use model (6) (see Table 2).

It is appropriate to compare the above findings with those found in the literature. The importance of price was confirmed by Howe and Linaweaver (1967) when they tested and rejected the hypothesis that the quantity of water demanded does not respond to price. Gottlieb 
(1963) found the elasticity of price ranges between -.66 and 01.24 when he examined the effect of price in a cross-sectional model of water use in Kansas. He did not find a significant effect of air-conditioning, climate, or rainfall. Grima (1972) found the elasticity of price to be -.93 in a cross sectional study of Toronto. Other significant variables which Grima tested were the value of the residence, size of the bill, size of the lot and the fixed charge. The above result is a confirmation of what Wong (1972) found in a cross-sectional and temporal study of Chicago and its suburbs. Price elasticity in Chicago was -.28 and in the suburbs was .02 . He could not establish the significance of income in either data.

Another significant finding in the study is that climate was identified as an important variable.* It was significant in models (2) and (4), when the average price, Pt, and the variable charge were included in the equations of the residential models. It also was significant in models (2) and (6), when commercial quantity and variable charge were included in the equations. The study could not establish the importance of climate in the industrial use. Industrial use was not affected by climate either because of idiosyncratic factors or because the cases of industrial use included in the study were limited.

The result of establishing the importance of climate in estimating water demand is a confirmation of the findings of Morgan and Smolen (1976) in finding temperature and precipitation important in explaining the

*Hereinafter the weather variable (Temperature/Precipitation) will be more accurately referred to as climate. 
variance in water data. Wong (1972) found temperature to be a significant variable. Gottlieb (1963) and Fourt (1958) did not find climate a significant factor in their studies. However, Forster and Beattie (1979) established the significance of the number of days of rainfall in the summer.

One of the important factors assumed to be effective in estimating water demand is income. One of the previous investigators who established the importance of income were Headley (1963). He established a significant linear relationship between median family income and water use in the San Francisco-Oakland area. Grima (1972) used the value of the residence as a proxy for income and established its significance. But Primeaux and Holman (1973) and Wong (1972) could not establish its significance.

Per capita income was used in the study, but no significant relationship could be established in any of the tested models. This result may be attributed to the rough measurement of income--per capita income of each county in which the water district is located was assigned to the case.

For a long time, water has been treated as a free good which does not fall under the rules of the production of economic goods. The estimation of water use by an urban area was based on a simple extrapolation of past trends of growth of the urban area. The size of the urban area is either measured by the growth of the population or the expansion of the area. This practice persists. However, it results in overestimation of water use. This was considered a safeguard for bad times of shortages or unexpected droughts, but proved to be a costly cushion. 
This overinvestment in waterworks leads to inefficient allocation of economic resources, which many urban areas cannot afford any longer. People and administrators began to look for an alternative, efficient method of estimating water demand. An economic approach which considers factors other than size is the alternative.

The results of this study are in line with the theory of estimating demand and a confirmation of previous findings in identifying price and climate as significant variables. The elasticity of price ranges between -.64 in the general model to -1.31 in the commercial model.

The average price as has been calculated and specified is a good measure. Average price was effective and significant in the residential model more than the variable charge. This indicates that in residential use, when most of it is essential use as is the case of small communities, variable charge is not effective as is the commercial use of water.

Industrial use is affected by factors different from those affecting residential and commercial uses. Fixed charge was found to be significant when industrial use was included.

Conduct of the study in Oregon allows examination of the variation in climate. Oregon climate varies from 7.6 to 99.08 on the climate index (see descriptive statistics, appendix). Host prior study areas had little variation in climate. Climate proved a highly significant variable in explaining residential water consumption.

\section{POLICY IMPLICATIONS}

The study leads to two policy implications. The first implication is that price is a good tool to use to promote the conservation of water 
regardless of the effect of climate in the area. The second implication is that average price is a sufficient policy tool for residential use.

\section{IMPLICATIONS FOR FURTHER RESEARCH}

It has been emphasized in the study that the price elasticity is negative, which suggests its use as a policy tool to promote efficient use of water. The problem that faces policymakers is balancing efficiency and equity.

It has been emphasized in previous sections of this study that water should be treated more like other commodities. The current practice of pricing of water shows some relationship to the principles of efficiency in its production and the principles of equity in collecting the total revenue from different users. Marginal cost pricing would seem to be the only way to solve the problem of efficiency and equity. However, marginal cost pricing should be introduced only if the societal welfare gains outweight the cost of implementing marginal cost pricing. The implementation of real marginal cost pricing would mean installing meters with a time mechanism which would allow a time specific price to be assessed for major consumers in response to peak and off-peak usage. The actual monetary gain from marginal pricing depends on the respective price elasticities of each demand for each consumer group served by the water utility. This suggests the need for further research on peak vs. non-peak pricing. For illustration, refer to Figure $16 . D_{1}$ refers to off-peak demand. It is inelastic demand curve--the consumers demand less water per unit 
price, indicating low but essential rates of consumption; $D_{2}$ refers to the peak demand--the consumers demand more water per unit price, an elastic demand curve indicating high consumption of unessential water, such as lawn sprinkling and swimming pool refills. (This analysis is based on discussion in Darr, Feldman, and Kamen in Feldman, Brees and Obeiker, 1981). $M C_{1}$ and $M C_{2}$ are distinct short-run marginal cost curves representing peak and off-peak costs of supplying given quantities of water. They are assumed to be constant with the linear demand function for simplification of analysis.

In principle, $\mathrm{MC}_{1}$ and $\mathrm{MC}_{2}$ represent the costs of two different products, off-peak water and peak water. Optimal pricing solutions require charging $\mathrm{P}_{1}$ for quantities demanded under $\mathrm{D}_{1}$ and $\mathrm{P}_{2}$ for quantities demanded under $\mathrm{D}_{2}$. Producers' surplus under $\mathrm{D}_{1}$ and consumers' surplus under $D_{2}$ cancel each other and the break even point is reached. This point can be illustrated by assuming that a flat rate, $\mathrm{P}_{a}$, is charged for both groups of consumers. It is calculated as the weighted average of $\mathrm{MC}_{1}$ and $\mathrm{MC}_{2}$,

Pricing according to this average cost does not result in an optimal pricing solution. The utility will experience a loss in supplying water to $\mathrm{D}_{2}$ equal to the area $\mathrm{P}_{a} \mathrm{GEP}_{2}$, here price for the unit of water sold is less than the marginal cost of the production of the unit. Similarly, the utility will earn a profit in supplying water to $D_{1}$ equal to the area $\mathrm{P}_{1}$ CAP ${ }_{\mathrm{a}}$; price exceeds marginal cost for the unit sold. By charging $\mathrm{P}_{\mathrm{a}}$ the firm will be at the optimal, zero, profit/loss position since the profits from $Q_{1 a}$ will equal the losses from supplying $Q_{2 a}$. Charging $P_{a}$ might be efficient for the firm since it covers the marginal cost of the production 


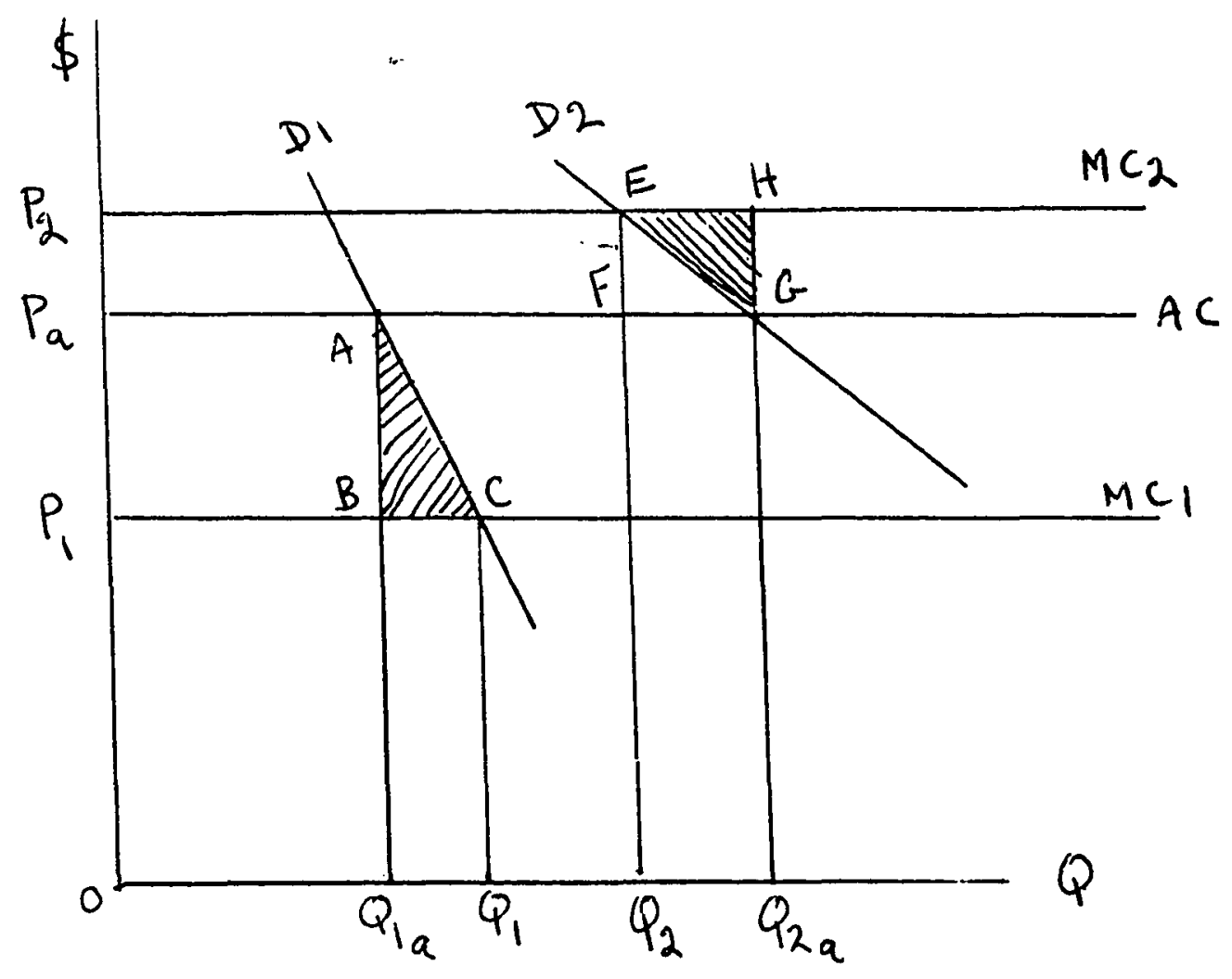

Figure 16. Equity and Efficiency Illustration 
but it is not equitable since essential and unessential demands are charged the same price.

A societal welfare gain results in the form of additional consumers' and producers' surplus if consumers were charged a price equal to marginal cost for each type of water demand. If price $\mathrm{P}_{a}$ were increased to $\mathrm{P}_{2}$ for consumers represented by demand $\mathrm{D}_{1}$, the quantity consumed would decrease from $Q_{2 a}$ to $Q_{2}$; the consumers' surplus loss equals the area $\mathrm{P}_{\mathrm{a}} \mathrm{GEP}_{2}$. This results in a net welfare gain equal to the area EHG. For the consumers represented by demand. $D_{1}$, a decrease in price from $P_{a}$ to $P_{1}$ would increase the quantity considered from $Q_{1 a}$ to $Q_{1}$ and result in consumer surplus of $\mathrm{P}_{1} \mathrm{CAP}_{\mathrm{a}}$. The net welfare gain is equal to the area $A B C$. The total societal welfare gain = EHG $+A B C$. There are two qualifications to the welfare gain: (1) the cost of time varying water meters and (2) the value of the societal welfare resulting from the introduction of the marginal cost pricing. The actual dollar gain from marginal pricing depends on the price elasticity of each consumer group.

In addition to peak and off-peak elasticity research, sampling households and firms within the water districts would allow a more definitive study of variables, such as income, number of bathrooms, size of family, etc., that were not well measured using district-wide averages. With a large enough sample for a range of districts having variation in price, stratifications could be done that would allow estimation of price elasticities for different household types.

More research on the effects of economies of scale on the production of water and its implication to the policy of consolidating small water districts is essential. Differential pricing among many small water 
districts is an apparent feature of costing and pricing policies in waterworks. A societal welfare benefit may be realized if the small water districts consolidate to capitalize on economies of scale and save on administrative costs. 


\section{BIBLIOGRAPHY}

Agthe, D. E., and R. B. Billings. "Dynamic Models of Residential Water Demand." Water Resources Research, 16, No. 3 (198C):476-480.

Baumann, D., and D. Dworkin. "Water Resources for Our Cities." AAG Resources Paper for College Geography, No. 78-2 (1978), 35 pp., Washington, D.C.

Berry, D. W., and A. W. Bonem. "Predicting the Municipal Demand for Water." Water Resources Research, 10, No. 6 (1974):1239-1242.

Billings, R. B., and D. E. Agthe. "Price Elasticities for Water: A Case of Increasing Block Rates." Land Economics, 56, No. 1 (1980):73-84.

Carver, P. H., and J. J. Boland. "Short-and-Long-Run Effects of Price on Municipal Water Use." Water Resources Research, 16, No. 4 (1980):690-616.

Columbia North Pacific Region (CNPR) Comprehensive Framework Study. Pacific Northwest River Basins Commission. Vancouver, Washington, September 1972.

Danielson, S. E. "An Analysis of Residential Demand for Water Using Micro Time Series Data." Water Resources Research, 15, No. 4 (1979): 763-767.

Domokos, M., J. Weber, and L. Duckstien. "Problems in Forecasting Water Requirements." Water Resources Bulletin, 12, No. 2 (1976): 263-275.

Environmental Protection Agency. Listing of Oregon Community Water Systems. Computer Printout, Region 10, Seattle, Washington (1983).

Feldman, S. L., J. Breese, and R. Obeiker. "The Search for Equity and Efficiency in the Pricing of a Public Service: Urban Water." Economic Geography, 57, No. 1 (1981): 78-92.

Foster, H. S., and B. R. Beattie. "Urban Residential Demand for Water in the United States." Land Economics, 55, No. 1 (1979):43-58.

Fourt, L. "Forecasting the Residential Demand for Water." Seminar paper, Agricultural Economics, University of Chicago, February 1968. Mimeographed. 
Gotclieb, M. "Urban Domestic Demand for Water: A Kansas Case Study." Land Ecunomics, 39, No. 2 (1963): 204-210.

Grima, A. P. Residential Water Demand: Alternative Choices for Management. Toronto: l'niversity of Toronto Press, 1972, $211 \mathrm{pp}$.

Grima, A. P. L. "The Impact of Policy Variables on Residential Water Demand and Related Investment Reyuirements." Water Resources Bulletin, 9, No. 4 (1973): 703-710.

Hinke, S. W. "Demind for Water Under Dynamic Conditions." Water Resources Researcin, 6, No. 5 (1970a): 1253-1261.

Halke, S. W. "Sume Behavioral (haracteristics Associated With Residential hater Price Changes." Water Resources, 6, No. 5 (1970b): $1383-1386$.

Haisen, R. D., and R. Narayanan. "A Monthly Time-Series Model of Municipal Water Demand." Water Resources Research, 1.7, No. '4 (1981): 578-585.

liaver, C. B., and J. R. Winter. Future Water Supply of London: in Economic dijpraisal. London, Ontario: Public Utility Commission, January 1963.

Headley, J. C. "The Relation of Family Income and Use of Water for Residential and Commercial purposes in the san FranciscoOakland Metropolitan Area." Land Ecomomic:s, 39, No. 4 (1963): $441-449$.

Howe, C. .i., and F. P. lialweaver, Jr. "The lmpact of price on Residential Water bernand and Its Relation io System Design and Prici structure." Water Resources kiscirrell, 3, iis. 10 (19hi): $40-4 \because$.

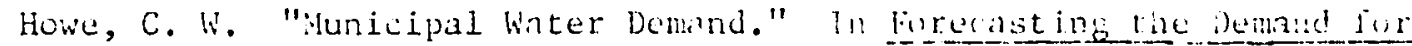
Water, edited by W. R. O. Sewoll and B. T. Bower. Detuwa: Queen's Printer, 1968.

Howe, C. W. "Water Pricing in Residential itran." Iournal AfWA, 60, No. 5 (1968): 407-41.L.

Howe, C. W., and W. J. Vaughan. "In-House Water Savings." Journal AWWA February 1972: 118-1.21.

Judy, R. W. "Yunicipal Water Demand: A Critique." In loorecasting the Demand for Water, edited by W. R. D. Sewell and B. T. Bower. Ottowa: Qucen's Printer, 1968. 
Klugman, R. R., and G. A. Tobin. "Disaggregate Models of Residential Water Demand: Iowa City, Iowa." Report, Department of Geography University of Iowa, 1982. Mimeographed.

Lee, M. Y., and R. D. Warren. "Use of a Predictive Model in Evaluating Water Consumption Conservation." Water Resources Bulletin, 17, No. 6 (1982): 948-954.

Lee, T. R. Residential Water Demand and Economic Development. Toronto: University of Toronto Press, 1967.

Linaweaver, F. P., Jr., J. C. Geyer, and J. B. Wolff. Residential Water Use Research Project (Final and Summary Report). A report to the Federal Housing Administration, Rep. V., phase two, Johns Hopkins University, Baltimore, Md., 1966.

Linsley, R. K., and J. B. Franzini. Water Resources Engineering. New York: McGraw-Hill, 1964.

MacLaren, J. F., Associates. "A Report to the Public Utilities Commission of Lond on on Waterworks Developments to 1985."

London, Ontario: Public Utilities Commission, December 1961.

Maier, W. J., J. DeZellar, and R. M. Miller. "Benefits from Water Conservation Depends on Comprehensive Planning." Water Resources Bulletin, 17, No. 4 (1981): 672-677.

Milliman, J. W. "Policy Horizons for Future Urban Water Supply." Land Economics, May 1963: 109-132.

Morgan, W. D. "Residential Water Demand: The Case for Micro-Data." Water Resources Research, 9, No. 3 (1973): 1065-1067.

Morgan, W. D. "A Time-Series Demand for Water Using Micro-Data and Binary Variables." Water Resources Bulletin, 10, No. 4 (1974): 697-702.

Musgrave, R. A., and Musgrave, P. B. Public Finance in Theory and Practice. New York: McGraw-Hill, 1976.

Nie, H. N., C. Hadlai, J. A. Jenkins, K. Steinbrenner, and D. H. Bent. Statistical Package for Social Sciences. New York: McGraw-Hil1, 1975.

Ostle, B., and R. W. Mensing. Statistics in Research (3rd Ed.). Ames: Iowa State University Press (1975).

Pindyck, R. S., and D. L. Rubinfeld. Econometric Models and Economic Forecasts. New York: McGraw-Hill, Inc., 1981.

Pitbaldo, J. R. "The Effects of Metering on the Domestic Consumption of Water. The City of St. Catherine's." B. A. Thesis, Department of Geography, University of Toronto, Toronto, 1967. 
Thornthwaite, C. W., and J. R. Mather. "Instructions for Computing Potential Evapotranspiration and the Water Balance." Drexel Institute of Technology, Laboratory of Climatology. Centron NJ, 10, No. 3 (1975).

Turnovsky, S. J. "The Demand for Water: Some Empirical Evidence on Consumers' Response to a Commodity Uncertain in Supply." Water Resources Research, 5, No. 2 (1969):350-361.

United States Congress, Senate Select Comittee on National Water Resources. Water Resources in the United States. 86th Cong., 2nd Sess., Comm. Print No. 31. Washington, D. C.: Government Printing Office, 1960.

U. S. Department of Health, Education and Welfare. Public Health Service. Working paper No. 54, February 1965.

U. S. Water Resources Council. The Nation's Water Resources: The Second National Assessment. Summary report, draft copy. Washington, D. C.: U. S. Water Resources Council, 1978.

Westgarth and Warren Company. Municipal Water Needs in the Norhtwest to the Year 2020.

Whipple, W., Jr. "An Economic Analysis of Water Conservation Policy." Water Resources Bulletin, 17, No. 5 (1981):814-819.

White, G. F. Water, Health, and Society: Selected Papers by Able Wolman. Bloomington, Indiana: Indiana University Press, ed. (1969).

Wilkinson, C. F. "Disguise Mask Water Problems." The Sunday Oregonian, Forum, Section E, October 16, 1983.

Wong, S. T. "A Model of Municipal Water Demand: A Case Study of Nor theastern Illinois." Land Economics, 48, No. 1 (1972):34-44.

Young, R. A. "Price Elasticity of Demand for Municipal Water: A Case Study of Tucson, Arizona." Water Resources Research, 9, No. 4 (1973): 1068-1072. 
APPENDIX 
APPENDIX

CONTENTS

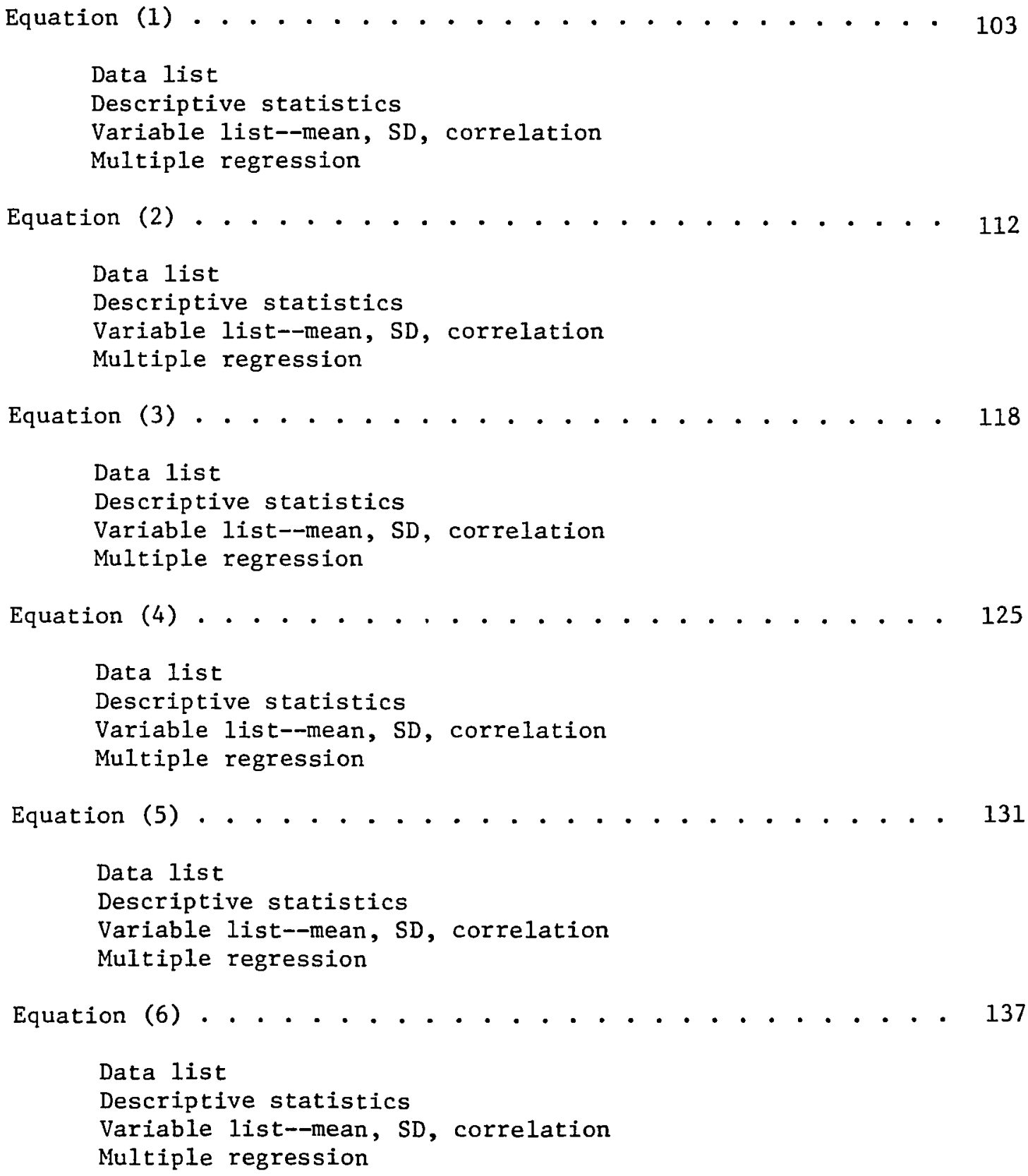


Equation (7) . . . . . . . . . . . . . . . . . . . 143

Data list

Descriptive statistics

Variable list--mean, SD, correlation

Multiple regression

Equation (8) . . . . . . . . . . . . . . . . . . . . 149

Data list

Descriptive statistics

Variable list--mean, SD, correlation

Multiple regression 
DEFINITIONS

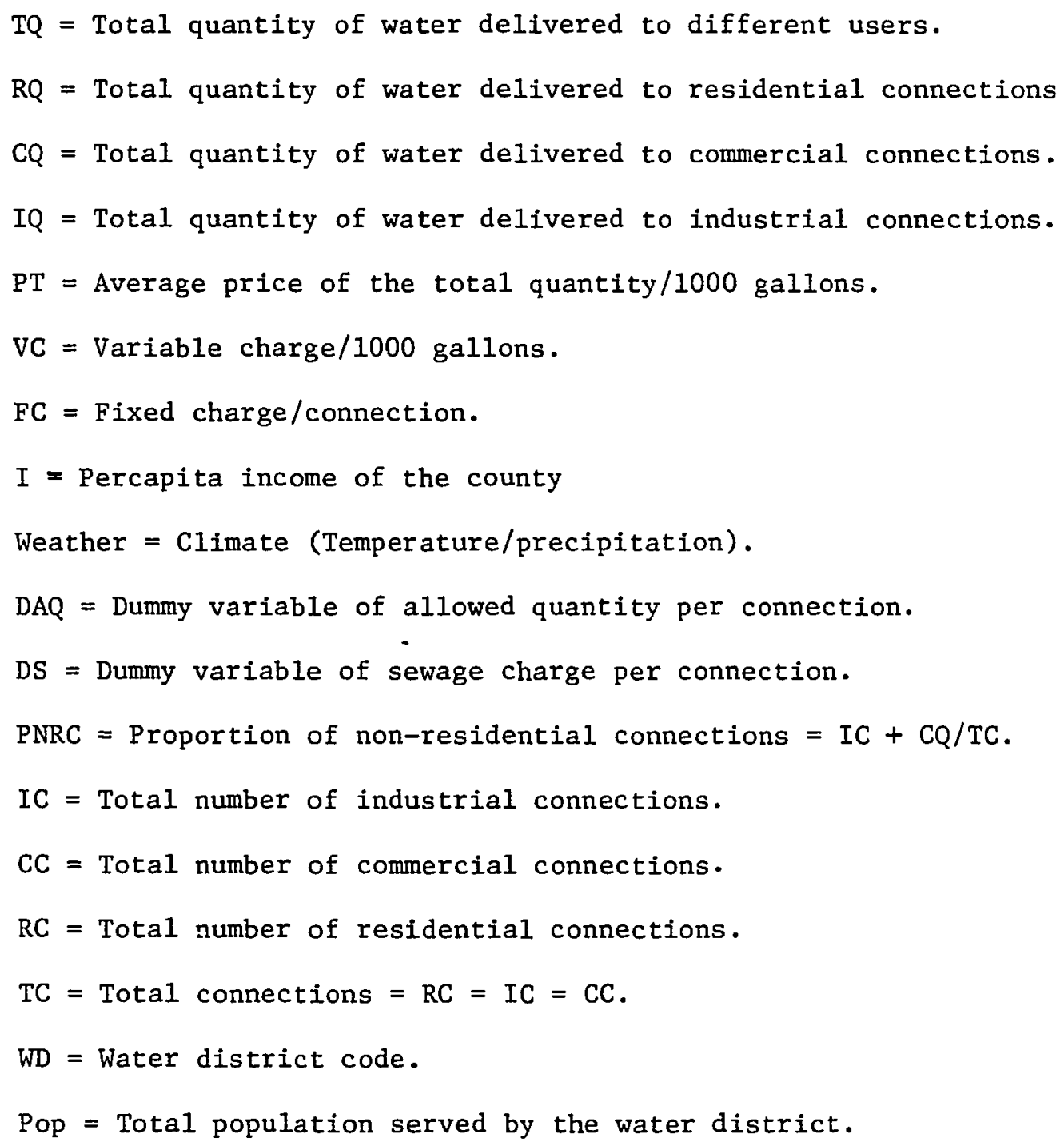


EQUATION (1) 


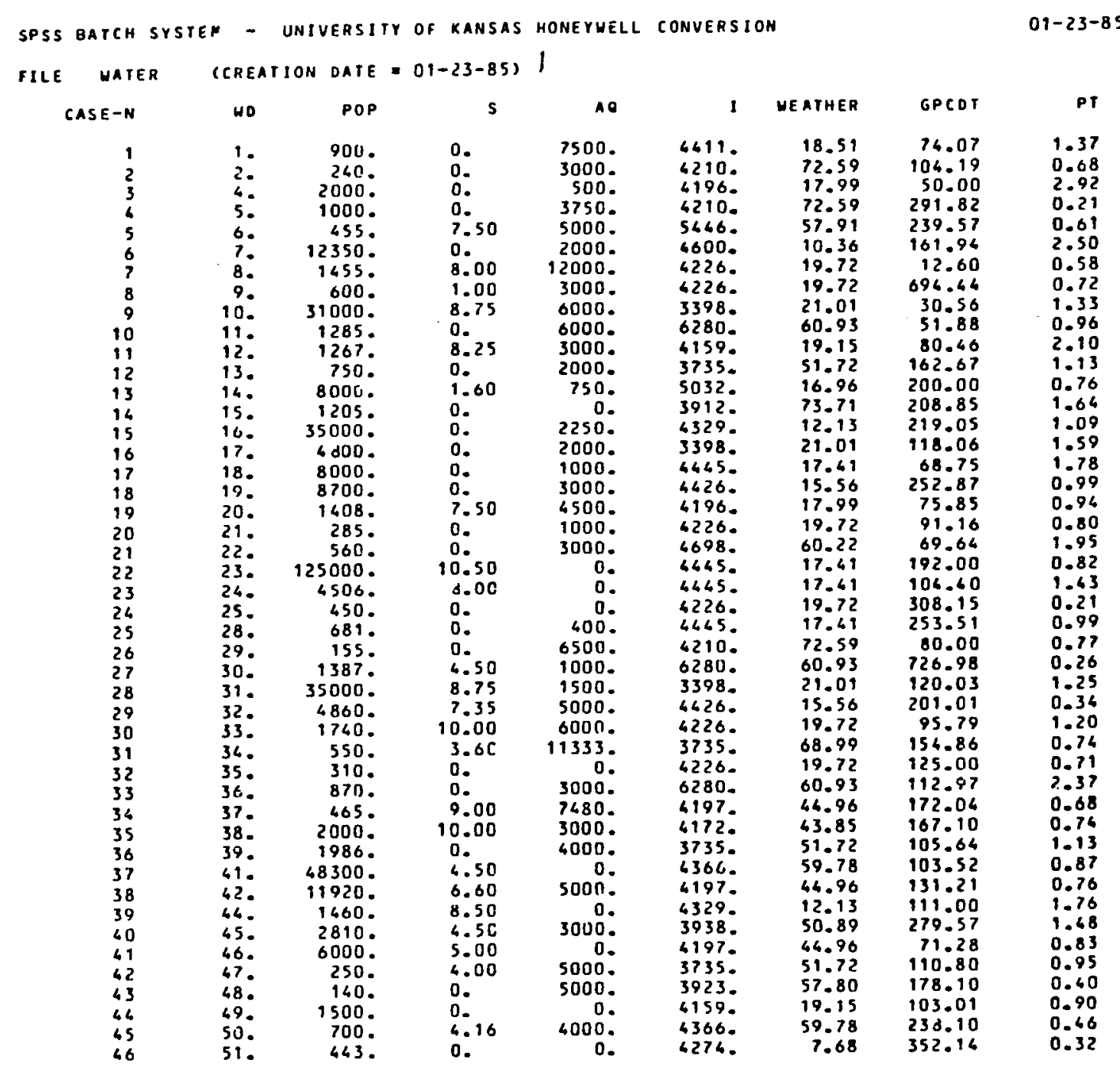


SPSS GATCH SYSTEP - UNIVERSITY OF KANSAS HONEYHELL CONVERSION

$09-23-85$

PAGE ?

TILE HATER (CREATION DATE $=09-23-85$ ) /

CASE -N
47
48
68
49
50
51
52
53
54
55
56
57
58
59
60
69
62
63
64
65
66
67
68
69
70
71
72
73
74
75
76
77
78
79
80
81
82
83
84
65
86
87
88
89
90
91
92
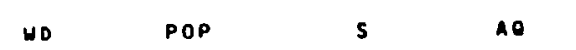

1 MEATHER
$196 . \quad 17.99$

GPCOT

200.10

283.87
277.92

49.87

107.61

4366.079 .76

5032.

5032. $\quad 16.96$

155.58
103.89

103.89
81.56

81.56
160.22

42.65

207.64

$6226 .-19.72$

56.14

4083 .

86.02

$4197 . \quad 44.96 \quad 398.10$

4010- $94.11 \quad 12.27$

$\begin{array}{rrr}6665 . & 17.41 & 96.12 \\ 60100 & 94.11 & 222.22\end{array}$

222.22

$16.96 \quad 53.43$

$72.59 \quad 270.22$

$\begin{array}{lll}4210 . & 72.59 & 270.22 \\ 6172 . & 43.85 & 141.51 \\ 5228 . & 25.07 & 157.32\end{array}$

$5250.0 \quad 5172$.

3740.04616.

25.07
$8.56 \quad 55.00$

205.82

125.98

3735.

65.78

173.33
212.52

$0 . \quad 4083$.

$\begin{array}{llll}0 . & 4274 . & 7.68 & 200.00\end{array}$

6000.4172.

3000 . 6141.

$63.85 \quad 182.66$

182.66
347.65

188.28

144.07

19.72

3000.

4600.

78.64
104.79

104.79
77.89

$\begin{array}{rrr}3735 . & 51.72 & 77.89 \\ 3398 . & 21.01 & 105.60\end{array}$

6226. $17.72 \quad 160.96$

$17.61 \quad 217.39$

217.39
128.72

$0 . \quad 6645$.

$\begin{array}{lll}4210 . & 72.59 & 128.72 \\ 4226 . & 19.72 & 199.26\end{array}$

$\begin{array}{lll}42260 & 19.72 & 199.26 \\ 4226 . & 19.72 & 73.11\end{array}$

$\begin{array}{llll}2500 . & 4226 . & 29.72 & 13.19 \\ 2500 . & 4083 . & 24.61 & 86.08\end{array}$

$4000 . \quad 4172 . \quad 43.85 \quad 101.79$

$\begin{array}{llll}0.0 & 6698 . & 60.22 & 347.22 \\ 3000 . & 3398 . & 21.01 & 121.74\end{array}$

333.33

0.25

0.34

0.92

0.66

1.28
1.21

1.04
1.30

1.01

0.76

0.69
0.52

4.75

1.67
0.29

1.15

0.60

1.05

0.81

0.42
0.48

1.18

0.49
0.37

0.37
0.60

0.28

0.03

0.64

0.70

0.48

0.78
1.11
1.72

1.16
0.98

0.52
1.33

1.36
1.02

1.02
0.52

0.51
0.48 
SPSS GATCH SYSTEM - UNIVERSiTY OF KANSAS hONEYHELL CONVERSION

FILE WATER (CREATION DATE $=01-23-85$ ) /

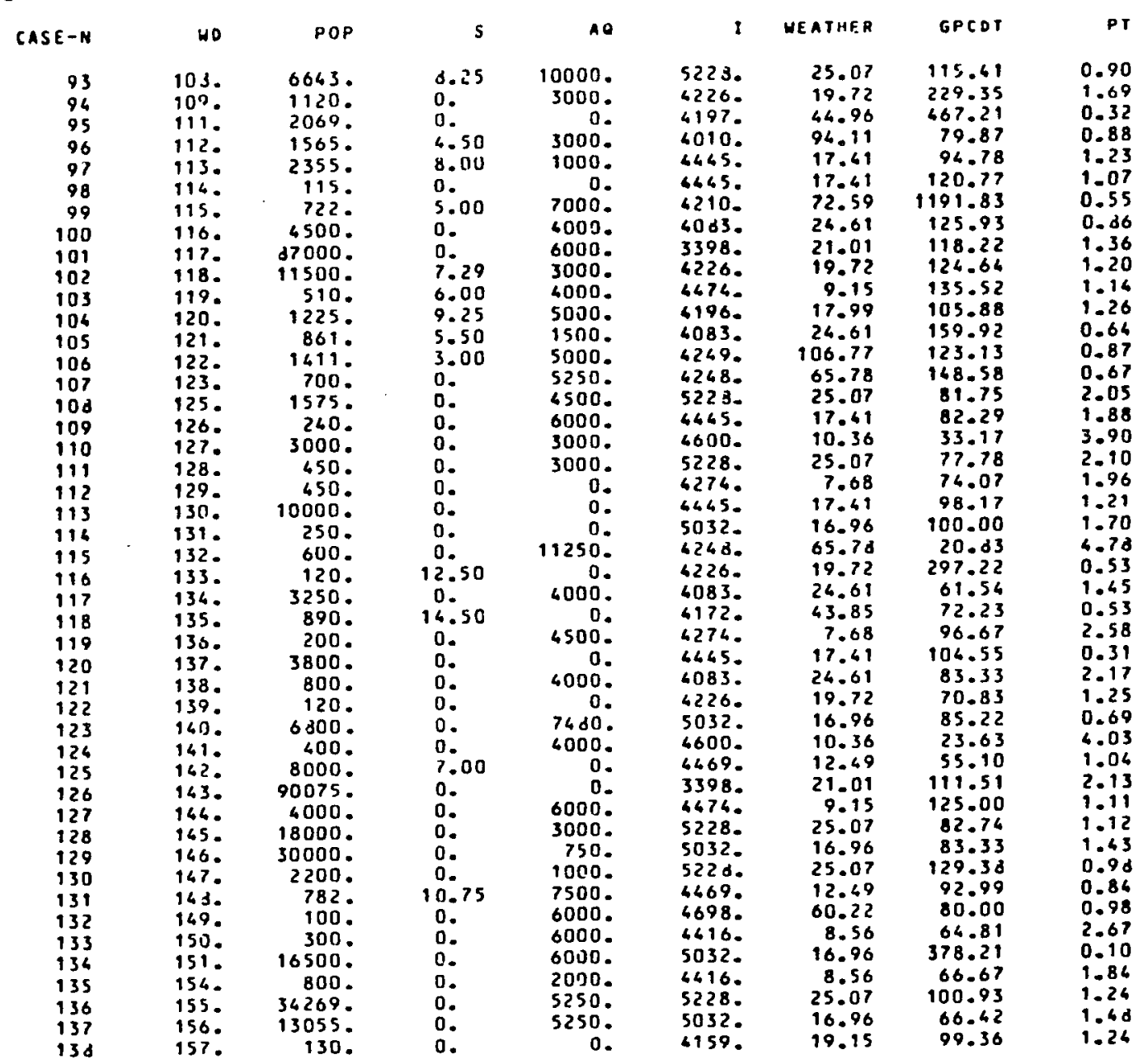


SPSS GATCH SYSTEM - UNIVERSITY OF KANSAS HONEYUELL CONUERSION

FILE WATER (CREATION DATE $=01-23-85$ )

CASE -
139
139
160
161
162
163
166
165
160
167
168
169
150
151
152
153
154
155
156

$\begin{array}{cr}\text { WD } & \text { POP } \\ & \\ 158 . & 200 . \\ 159 . & 1163 . \\ 160 . & 12000 . \\ 161 . & 1200 . \\ 162 . & 3504 . \\ 163 . & 3500 . \\ 164 . & 3000 . \\ 165 . & 972 . \\ 166 . & 2465 . \\ 167 . & 250 . \\ 169 . & 11800 . \\ 170 . & 945 . \\ 171 . & 300 . \\ 172 . & 95 . \\ 173 . & 2800 . \\ 174 . & 63 . \\ 176 . & 250 . \\ 177 . & 6000 .\end{array}$

0.
0.
0
0
0
7
0.0
0
0
0
0.
0.
0
0
0
0.
0.

$\begin{array}{lr} & 5 \\ 0 . & 0 . \\ 0 . & 3000 . \\ 0 . & 3750 . \\ 0 . & 6000 . \\ 0 . & 2250 . \\ 7.50 & 0 . \\ 0 . & 4000^{\circ} \\ 0 . & 2250 . \\ 9.50 & 3000 . \\ 0 . & 4000 . \\ 0 . & 3750 . \\ 0 . & 4500 . \\ 0 . & 3000 . \\ 0 . & 0 . \\ 0 . & 0 . \\ 0 . & 7500 . \\ 0 . & 4090 . \\ 0 . & 2700 .\end{array}$

1
4600.
5032.
3398.
5032.
5032.
50320
4626.
5228.
5228.
4276.
5032.
4276.
4274.
3912.
5032.
4033.
4210.
6083.

WEATHER

GPCOT

PT

$\begin{array}{rr}10.36 & 166.67 \\ 16.96 & 87.69\end{array}$

0.98
1.50

$11.01 \quad 114.58$

1.17

$\begin{array}{lll}16.96 & 108.33 & 0.95 \\ 6.96 & 77.83 & 1.37\end{array}$

169.012000

162.

2700 .

6083.

$\begin{array}{rrr}16.96 & 219.05 & 0.16 \\ 15.56 & 66.67 & 2.92\end{array}$

$25.07 \quad 111.13 \quad 0.59$

$25.07 \quad 209.60 \quad 0.76$

$\begin{array}{rrr}7.68 & 126.67 & 1.43 \\ 16.96 & 145.90 & 1.34\end{array}$

$\begin{array}{lll}7.68 & 952.38 & 0.38 \\ 7.68 & 119.11 & 1.66\end{array}$

$\begin{array}{lll}7.68 & 119.11 & 1.66 \\ 73.71 & 157.89 & 0.60\end{array}$

$\begin{array}{lrl}76.96 & 80.36 & 0.91\end{array}$

$\begin{array}{llll}24.61 & 102.04 & & 0.96 \\ 73.53 & & 1.53\end{array}$

$\begin{array}{rrr}72.59 & 133.33 & 1.15 \\ 24.61 & 77.78 & 1.66\end{array}$ 
FILE WATER (CHEATION OATE = 01-23-25)

VARIABLE POP

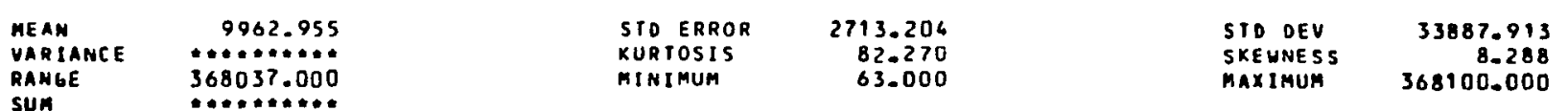

MISSING OBSERVATIONS -

VARIABLE GPCOT

\begin{tabular}{|c|c|c|c|c|c|c|}
\hline $\begin{array}{l}\text { MEAN } \\
\text { VARIANCE } \\
\text { RAKGE } \\
\text { SUR }\end{array}$ & $\begin{array}{r}158.130 \\
21002.517 \\
1179.554 \\
24668.327\end{array}$ & & $\begin{array}{l}\text { STO ERROR } \\
\text { KURTOSIS } \\
\text { MINIMUM }\end{array}$ & $\begin{array}{l}11.822 \\
21.689 \\
12.274\end{array}$ & $\begin{array}{l}\text { STO DEV } \\
\text { SKEENESS } \\
\text { MAXI MUM }\end{array}$ & $\begin{array}{r}147.657 \\
4.052 \\
1191.828\end{array}$ \\
\hline VALID OB & IONS - & 156 & & G OBSERVATIONS & 0 & \\
\hline
\end{tabular}

VALIO OBSERVATIONS - 156

VARIAGLE PT

\begin{tabular}{|c|c|c|c|c|}
\hline $\begin{array}{l}\text { MEAN } \\
\text { VARIANCE } \\
\text { RANGE } \\
\text { SUA }\end{array}$ & $\begin{array}{r}1.142 \\
0.598 \\
4.675 \\
178.224\end{array}$ & $\begin{array}{l}\text { STO ERROR } \\
\text { XURTOSIS } \\
\text { MINIMUM }\end{array}$ & $\begin{array}{l}0.062 \\
0.792 \\
0.102\end{array}$ & $\begin{array}{l}\text { STO OEV } \\
\text { SKEUNESS } \\
\text { MAXIMUH }\end{array}$ \\
\hline
\end{tabular}

MISSING OBSERVATIONS -

0

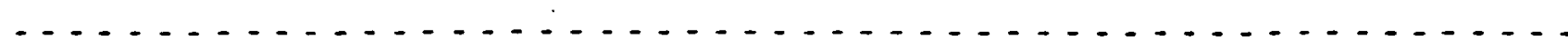

YARIABLE AO

MEAN
VARIANCE
RANGE
SUA

STO ERROR

KURTOSIS

219.078

0.464

STO DEV

\begin{tabular}{l}
2736.288 \\
SXE UNESS \\
\hline TAXIMUE
\end{tabular}

VALIO OBSERVATIONS -

156

MISSING OBSERVATIONS -

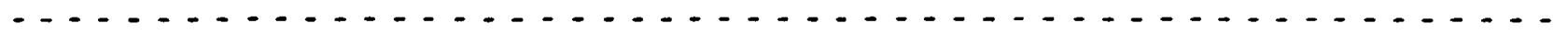




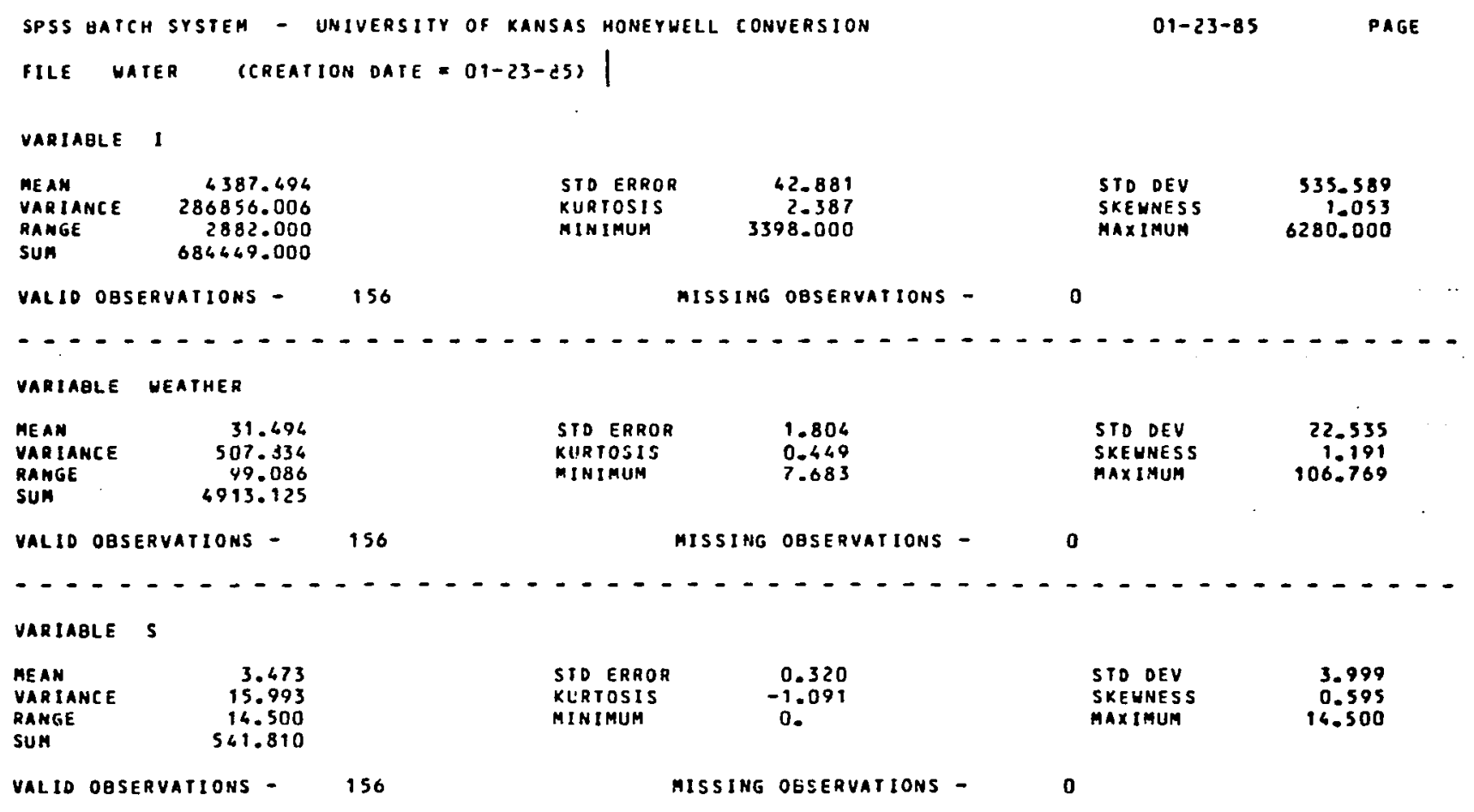


SPSS UATCH SYSTEN - UIJIVERSITY OF KANSAS HONEYWELL CONVERSION

$11-06-34$

PAGE

File Water (CREATION DATE = 11-06-RG) 1

MULTIPLE REGRESSION

VARIAGLE LIST NUYGER 1. LISTHISE DELETION OF MISSING DATA.

MEAA STO DEV LABEL

LOGGPCDT $4.89 t \quad 0.682$

LOGPI $\quad-0.07 C \quad 0.655$

DAO $0.763 \quad 0.627$

$\begin{array}{lrr}\text { LOG } & 8.375 & 0.119 \\ & 31.494 & 22.535\end{array}$

$\begin{array}{lrr}\text { LEATHER } & 31.494 & 22.535 \\ \text { OS } & 0.497 & 0.501\end{array}$

N OF CASES $=156$

CORRELATION

LGGGPCD

LOGPI

DAQ

LOG I

WEATHER

LOGP T

DAQ

LOGI

WEATHER

-0.613
1.000

-0.013
-0.035

-0.035
0.258

0.258

0.090

0.084

$-0.030$

$-0.133$

$-0.262$

$-0.035$

0.084

1.000

0.099

0.039
-0.029

0.058
-0.030

-0.030
0.099
1.000

$1.0 n 0$

$-0.086$

$-0.096$

0.020

0.070
-0.133
-0.038

0.031

$-0.086$

1.000

0.144

DS

\subsection{2
-0.262}

$-0.029$

$-0.094$

0.144 
FILE WATER (CREATION DATE $=19-96-84) \div$

$$
\text { - . multiple regatession.... }
$$

EQUATION NUMBER 1.

DEPENDENT VAPTABLE.. LOGGPCDT

BEGINNING gLOCK NUMBER 1. METHOD: STEPHISE

$\begin{array}{rrrrrrr}\text { STEP } & \text { MULIR } & \text { RSQ } & \text { AOJRSQ } & \text { F(EQU) } & \text { SIGF } & \text { RSQCH } \\ 1 & 0.6133 & 0.3761 & 0.3720 & 92.825 & -.060 & 0.3761 \\ 2 & 0.0145 & 0.3776 & 0.3695 & 66.678 & 0.700 & 0.7016 \\ 3 & 0.6148 & 0.3780 & 0.3657 & 30.791 & 0.000 & 0.0004 \\ 4 & 0.6150 & 0.3732 & 0.3617 & 22.959 & 0.060 & 0.0002 \\ 5 & 0.6150 & 0.3782 & 0.3575 & 18.249 & 0.0 C 0 & 0.0001\end{array}$
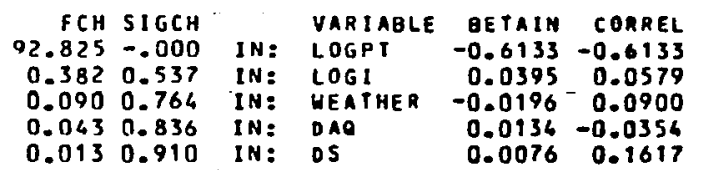

VARIABLE (S) ENTERED ON STEP NUMBER 5.. DS

\section{MUL IIPLE}

R SQUARE
AOJUSTED R SQUARE

0.61500
0.37823
$c .35750$
0.54648

R SOUARE CHANGE
F CHAHGE

F CHALIGE

SIGNIF F CHANGE

0.00005 0.0127

VARIABLES IN the EquATIOH

\begin{tabular}{|c|c|c|c|c|c|}
\hline VARIAELLE & B & SE B & BETA & & SIG \\
\hline $\begin{array}{l}\text { LOGPT } \\
\text { LOGI } \\
\text { WEATHER } \\
\text { DAQ } \\
\text { OS } \\
\text { (C ONSTAHT) }\end{array}$ & $\begin{array}{r}-C .04011 \\
C .21403 \\
-0.63804 E-03 \\
0.02151 \\
C .31034 \\
2.97721\end{array}$ & $\begin{array}{l}0.07071 \\
0.37895 \\
0.00200 \\
0.10394 \\
0.99160 \\
3.17358\end{array}$ & $\begin{array}{r}-0.01515 \\
0.03692 \\
-0.02109 \\
0.01346 \\
0.06760\end{array}$ & $\begin{array}{r}-9.052 \\
0.565 \\
-0.319 \\
0.207 \\
0.113 \\
0.937\end{array}$ & $\begin{array}{l}-.0000 \\
0.5731 \\
0.7504 \\
0.8364 \\
0.9103 \\
0.3504\end{array}$ \\
\hline
\end{tabular}

FOR HLOCK AUMAER 1 POUT $=1.100$ LIMITS REACHED.
ANALYSIS OF VARIANCE REGRESSION RESIDUAL

DF
5
150

SUM OF SQUARES

27.24969
44.79549
18.24940

SIGNIF F $=0.0000$

18.24940 
EQUATION (2) 


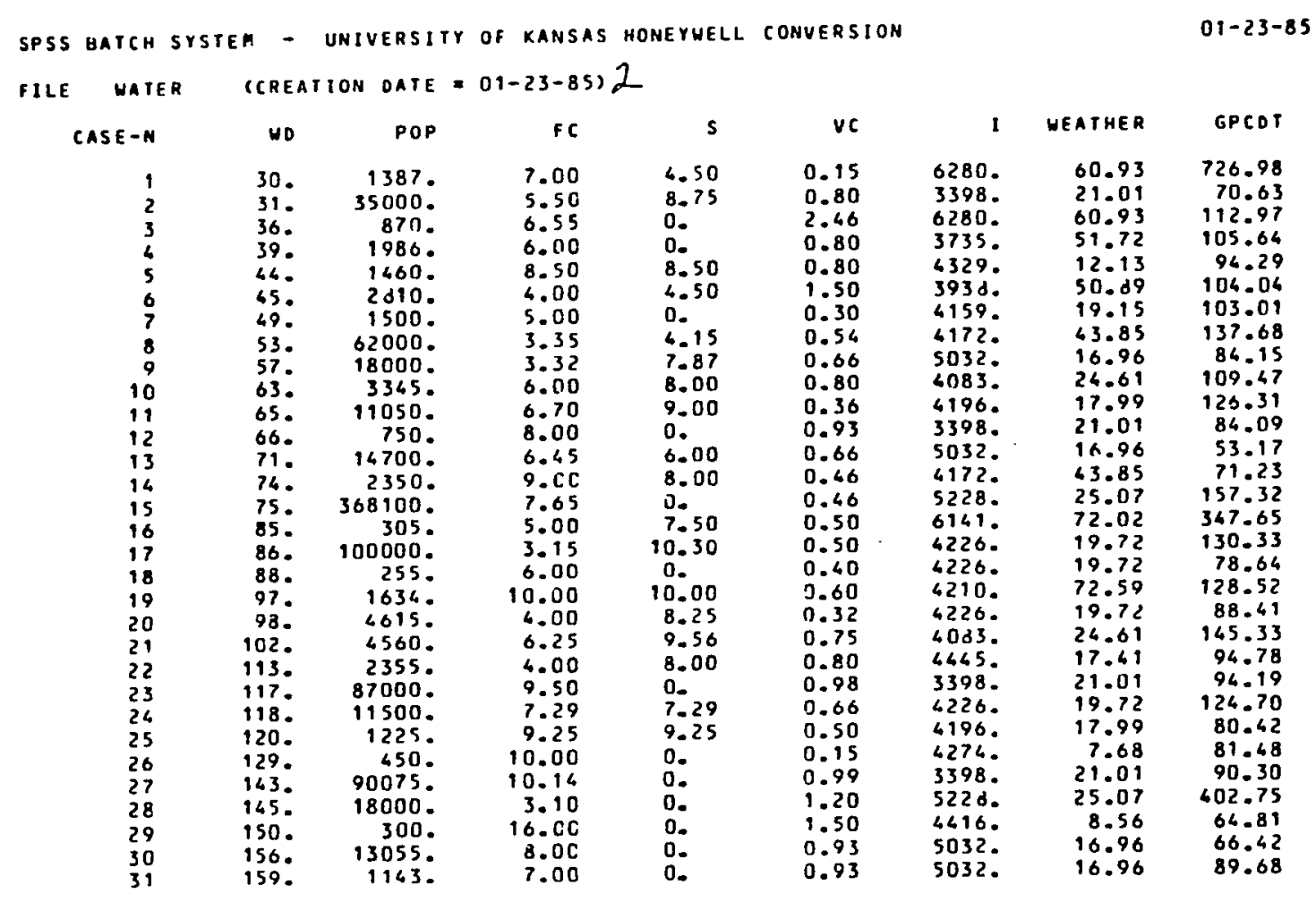


file Hater (creation oAte $=01-23-85) 2$

VARIAGLE POP

\begin{tabular}{|c|c|c|c|c|c|}
\hline $\begin{array}{l}\text { MEAN } \\
\text { VAR IANCE } \\
\text { RANGE } \\
\text { SUR }\end{array}$ & $\begin{array}{r}27799.355 \\
3679.21 .00 \\
861780.000\end{array}$ & $\begin{array}{l}\text { STD ERROR } \\
\text { KURTOSIS } \\
\text { AINIMUM }\end{array}$ & $\begin{array}{r}12429.189 \\
20.602 \\
255.000\end{array}$ & $\begin{array}{l}\text { STO DEV } \\
\text { SKEUNESS } \\
\text { MAXIMUM }\end{array}$ & $\begin{array}{r}69202.795 \\
4.292 \\
368100.000\end{array}$ \\
\hline
\end{tabular}

SUM 861780.000

31

MISSING OUSERVATIONS -

ID OBSERvations -

VARIABLE GPCDT

$\begin{array}{lr}\text { MEAN } & 137.077 \\ \text { VARIANCE } & 17398.226 \\ \text { RANGE } & 673.801\end{array}$

4249.387

KLiRTOSTS

MINIMUM

\subsection{929}

53.174

STO DEV
SKENNESS

MAXI IMUM

VALID OBSERVATIONS -

MISSING OBSERVATIONS -

VARIABLE VC

\begin{tabular}{|c|c|c|c|c|c|}
\hline $\begin{array}{l}\text { MEAN } \\
\text { VARIANCE } \\
\text { RANGE } \\
\text { SUM }\end{array}$ & $\begin{array}{r}0.755 \\
0.210 \\
2.310 \\
23.390\end{array}$ & $\begin{array}{l}\text { STE ERROR } \\
\text { KURTOSIS } \\
\text { MINIMUM }\end{array}$ & $\begin{array}{l}0.082 \\
5.487 \\
0.150\end{array}$ & $\begin{array}{l}\text { STD DEV } \\
\text { SXEUNESS } \\
\text { MAXIMUM }\end{array}$ & $\begin{array}{l}0.458 \\
1.881 \\
2.660\end{array}$ \\
\hline
\end{tabular}

VALID OBSERVATIONS - 31

MISSIMG OgSERVATIONS - 0

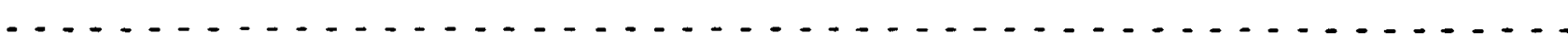

VARIABLE FC

MEAN $\quad 6.829$

$\begin{array}{lr}\text { VARIANCE } & 7.544 \\ \text { RANGE } & 12.900\end{array}$

$\begin{array}{ll}\text { RANGE } & 12.900 \\ \text { SUM } & 211.700\end{array}$

SID ERROR
KURTOSIS

XURTOSIS
MINIMUM

0.493
2.692
3.100

STO DEV

SXEWNESS

VALID OBSERVATIONS

MISSING OBSERVATIONS

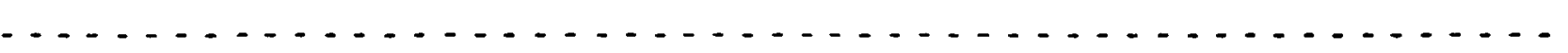


SPSS BATCH SYSTEM - UNIVERSITY OF KANSAS HONEYHELL CONVERSION

FILE HATER (CREAIION OATE $=01-23-85$ ) 2

VARIABLLE I

MEAN
YARIANCE
OOS57.710

$\begin{array}{lr}\text { VARIANCE } & 608794.946 \\ \text { RAMGE } & 202.000\end{array}$ 138189.000

STO ERROR

KURTOSIS
MINIMUA

140.138
0.707

0.707
3398.000

STO DEV

SKEUNESS
MAXIMUM

780.253
0.974

SUA

VALIO OBSERVATIONS - 31 MISSING OBSERVATIONS - 0

VALIO OBSERVATIONS - 31 MISSING OBSERVATIONS - 0

YARIABLE HEATHER

MEAN 28.63

VARIANCE $\quad 336.713$

RAHGE $\quad 64.907$

887.810

STD ERROR

KURTOSIS
MINIMUM

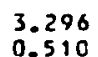

3.296
0.510

7.683

STO DEV

VALIO OBSERVATIONS -

31

MISSING OBSERVATIONS

0

VARIABLE S

VARIAB

$\begin{array}{lr}\text { MEAN } \\ \text { VARIANCE } & \mathbf{4 . 4 9 7}\end{array}$

$\begin{array}{ll}\text { VARIANCE } & 17.031 \\ \text { RANGE } & 10.300\end{array}$

SUM

139.420

VALID OBSERVATIONS -

$\begin{array}{lclr}\text { STO ERROR } & 0.741 & \text { STD DEV } & 6.127 \\ \text { KURTOSIS } & -1.857 & \text { SKEUNESS } & -0.040 \\ \text { MINIMUM } & 0.0 & \text { MAXIMUM } & 10.300\end{array}$

MISSING OBSERYATIONS - 0 
SPSS UATEI SYSTE. - UNIVERSTTY OF KANSAS HONEYHELL COAUERSION

FILE HATER (CREATION DATE $=11-09-34) 2$

VARIAULE LIST NUMBER 1. LISTHISE DELETICN OF MISSING OATA.

$$
\text { MEAN STO DEV LABEL }
$$

\begin{tabular}{|c|c|c|c|c|c|c|}
\hline $\begin{array}{l}\text { LUGGPCDT } \\
\text { LOGVC } \\
\text { LOUFC } \\
\text { LOGL } \\
\text { WEATHER } \\
\text { DS }\end{array}$ & $\begin{array}{r}4.756 \\
-0.646 \\
1.845 \\
3.329 \\
28.039 \\
0.581\end{array}$ & $\begin{array}{r}0.585 \\
0.605 \\
0.400 \\
0.107 \\
.18 .350 \\
0.502\end{array}$ & .... & $\ldots$ & - & $\cdots$ \\
\hline $\begin{array}{l}\text { N OF CASES } \\
\text { CORRELATION }\end{array}$ & $=$ & $31 \ldots$ & $\cdots-$ & $\cdots-\quad-$ & $\ldots$. & . \\
\hline & LOGGPCDT & LoGVe & LOGFC & LOGI & WEATHER & os \\
\hline $\begin{array}{l}\text { LUGGPCDT } \\
\text { LUGVG } \\
\text { LUGFC } \\
\text { LOGI } \\
\text { UEATHER } \\
\text { OS }\end{array}$ & $\begin{array}{r}1.000 \\
-0.604 \\
-0.069 \\
0.272 \\
0.412 \\
0.128\end{array}$ & $\begin{array}{r}-0.604 \\
1.000 \\
0.027 \\
-1.094 \\
0.035 \\
-0.223\end{array}$ & $\begin{array}{r}-0.060 \\
0.027 \\
1.006 \\
-0.167 \\
-0.11 C \\
-0.332\end{array}$ & $\begin{array}{r}0.273 \\
-0.094 \\
-0.967 \\
1.000 \\
0.351 \\
0.032\end{array}$ & $\begin{array}{r}0.412 \\
0.035 \\
-0.110 \\
0.351 \\
1.000 \\
0.268\end{array}$ & $\begin{array}{r}0.128 \\
-0.223 \\
-0.332 \\
0.032 \\
0.208 \\
1.000\end{array}$ \\
\hline
\end{tabular}


SPSS BATCH SYSTEP - UNIVERSITY OF KANSAS hONEYHELl CONVERSion

FILE WATER (CREATION DATE $=11-09-84) 2$

*.. multiple reggaession....

EQUATION NUMBER 1.

dependent vartagle.. loggrcot

GEGINNING gloCK NUMGER 1. METHOD: STEPHISE

STEP RULTR RSQ AOJKSE ...F(EQU) SIGF

1 U.6037 0.3644 AOJKSQ

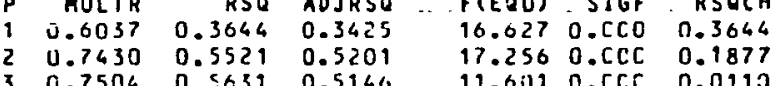

4 C. 0.7528 0.5667 0.5000

17.2560. CCC 0.1877

. $F$ CH SIGCH

11.7320 .002

$11.6010 .0 C E$

0.0035

0.682 .0 .416
0.2130 .648

$6.550 \quad 0.001 \quad 0.0004$

0.0260 .874

VARIAGLE(S) ENTERED ON STEP NUIAER 5.. LOGFC

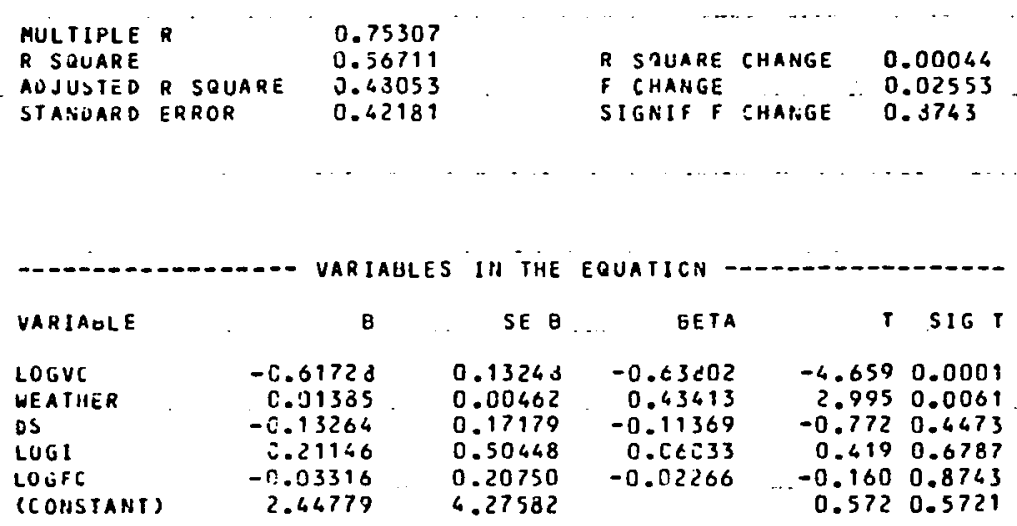

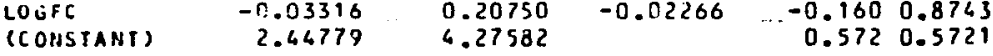

FOn GLOCK NUMBER 1 POUT $=1.100$ LiMITS REACHEO. 
118

EQUATION (3) 


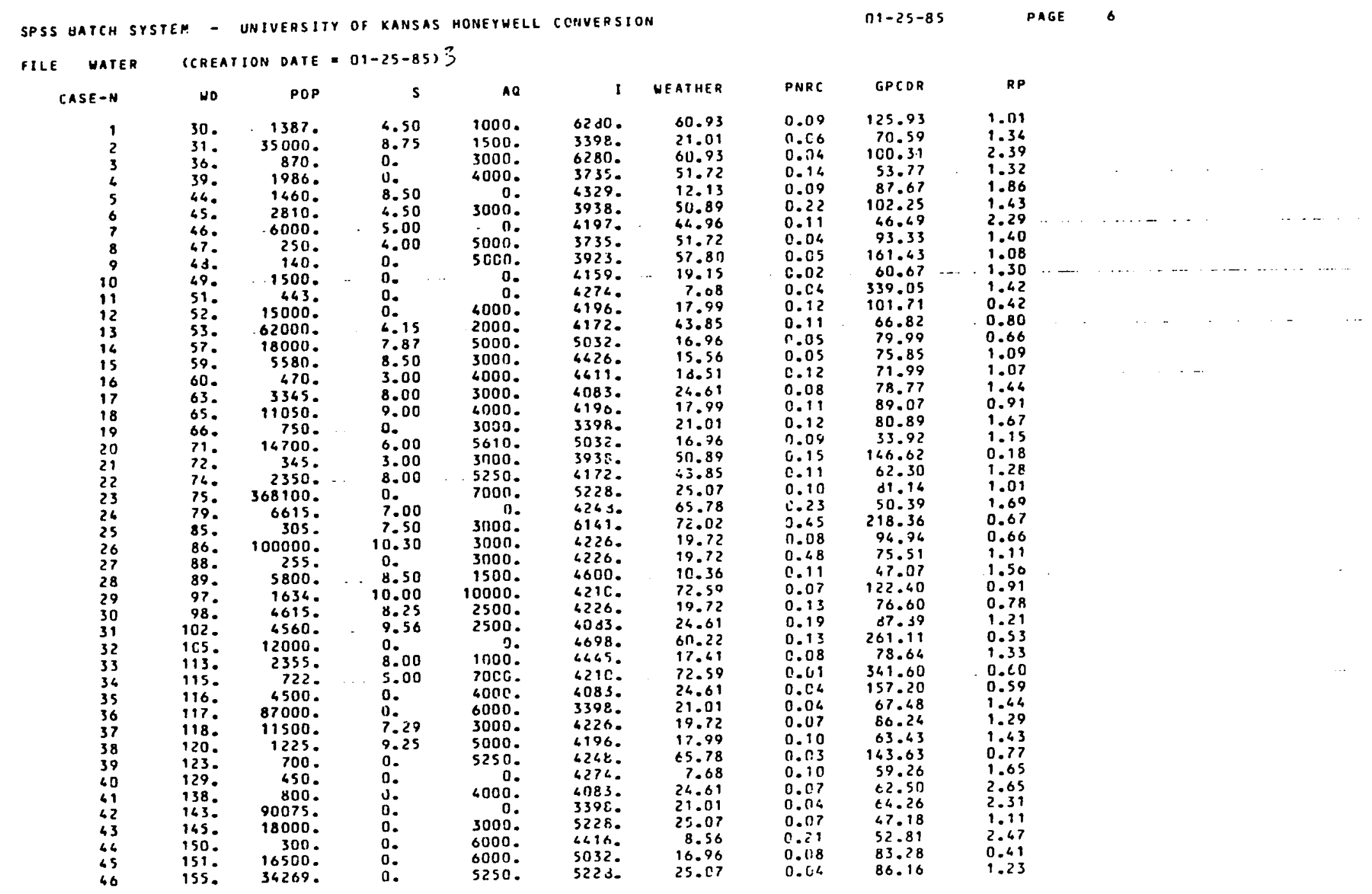


SPSS BATCH SYSTEP - UNIVERSIT, OF KANSAS HONEYUELL CONVERSION

file Water (CREATION Date $=01-25-85$ ) 3

CASE

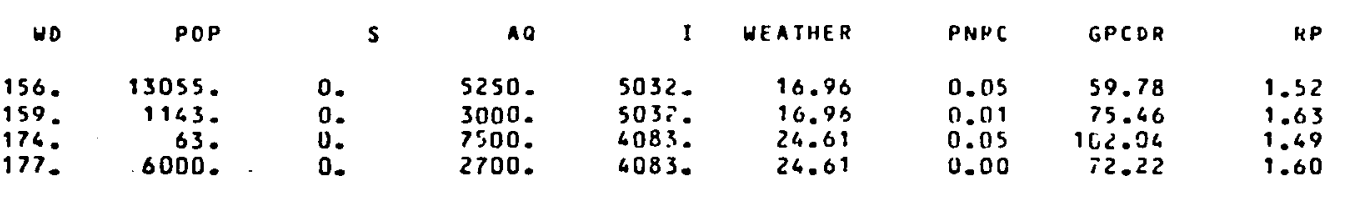


SPSS GATCH SYSIEM - UHIVERSITY OF KANSAS HONEYHELL CONVERSIOH

FILE WATER (CREATION DATE $=01-25-85$ ) 3

VARIABLE POP

MEAN UARIANCE 19559.540

VARIANCE

SUAE $\quad 977077.000$

VALID OBSERVATIONS -

so
STO DEV 55423.716

SKEWNESS
AXI:AUM

0

VARIABLE GPCDR

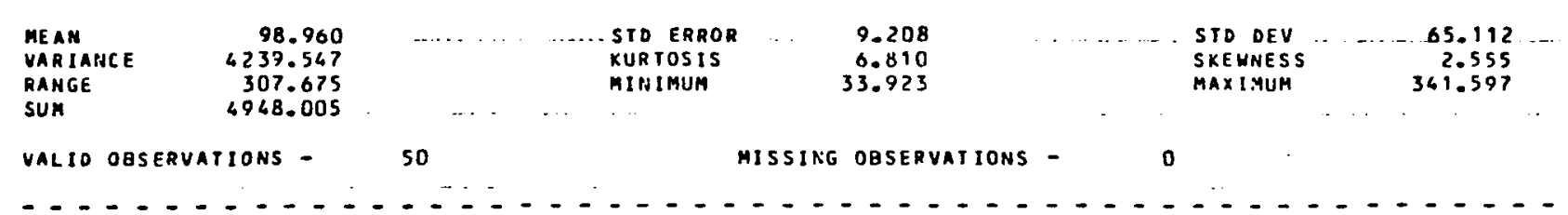

VARIABLE RP

VARIABLE RP

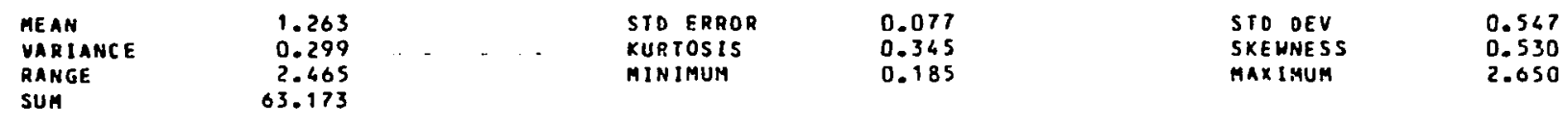

MISSIN:G OQSERVATICNS -

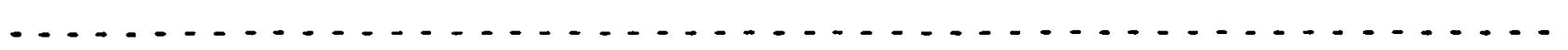

VARIABLE aO

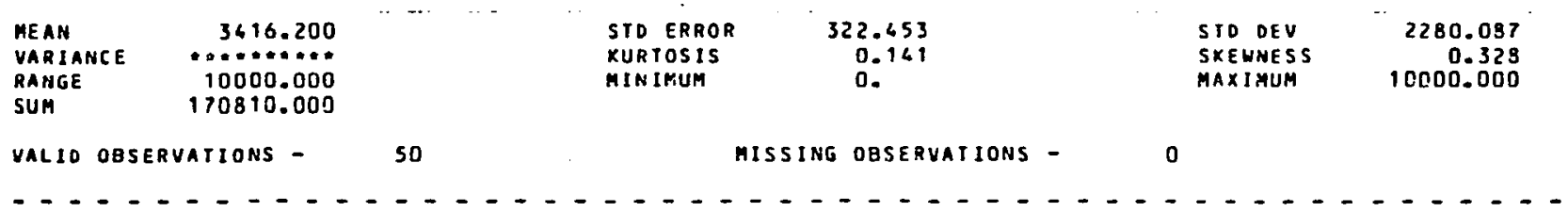


SPSS BATCH SYSTEM - UNIVERSITY OF KANSAS HONEYHELL CONVERSION

file water (CREATION DATE $=01-25-85) 3$

\section{VARIABLE I}

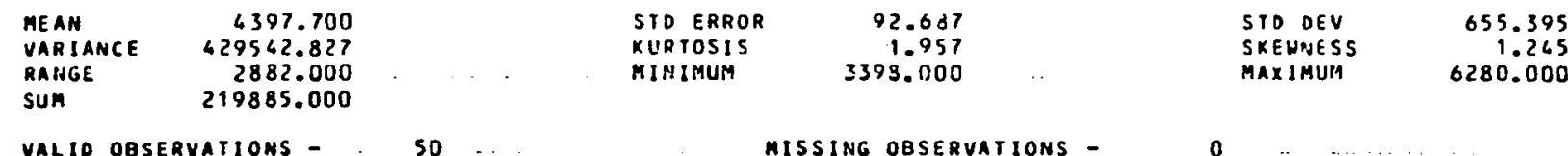

\section{VALIO OBSERVATIONS}

50

MISSING OBSERVATIONS -

\section{VARIABLE WEATHE}

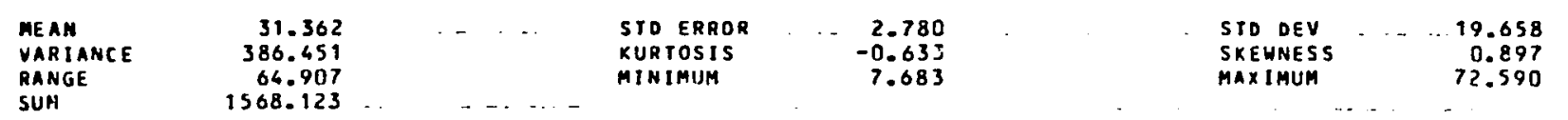

MISSING OBSERVATIONS -

0

VALID OBSERVATIONS -

\section{VARIABLE S}

$\begin{array}{lr}\text { MEAN } & 3.668 \\ \text { VARIANCE } & 15.155 \\ \text { RANGE } & 10.300\end{array}$

183.420

VALIO OBSERVATIONS - SO

VARIABLE PNRC

$\begin{array}{ll}\text { MEAN } & 0.102 \\ \text { VARIANCE } & 0.008 \\ \text { RANGE } & 0.478 \\ \text { SUM } & 5.087\end{array}$

VALIO OBSERVATIONS -

\section{STO ERROR \\ XURTOSIS \\ MINIMUM \\ 0.551 \\ -1.633
0.}

STO DEV
SKEWNESS

SKEWNESS
MAXIMUM

3.893
0.336

0.336
10.300

MISSING OBSERVATIONS - 
SPSS GATCH SYSTEM - UAIVERSITY OF KANSAS HONEYHELL CONUERSION

FILE WATER (CREATION DATE $=11-06-86) 3$

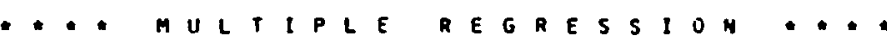

VARIABle LIST NuMger 1. LISTHISE deletion OF MISSING data.

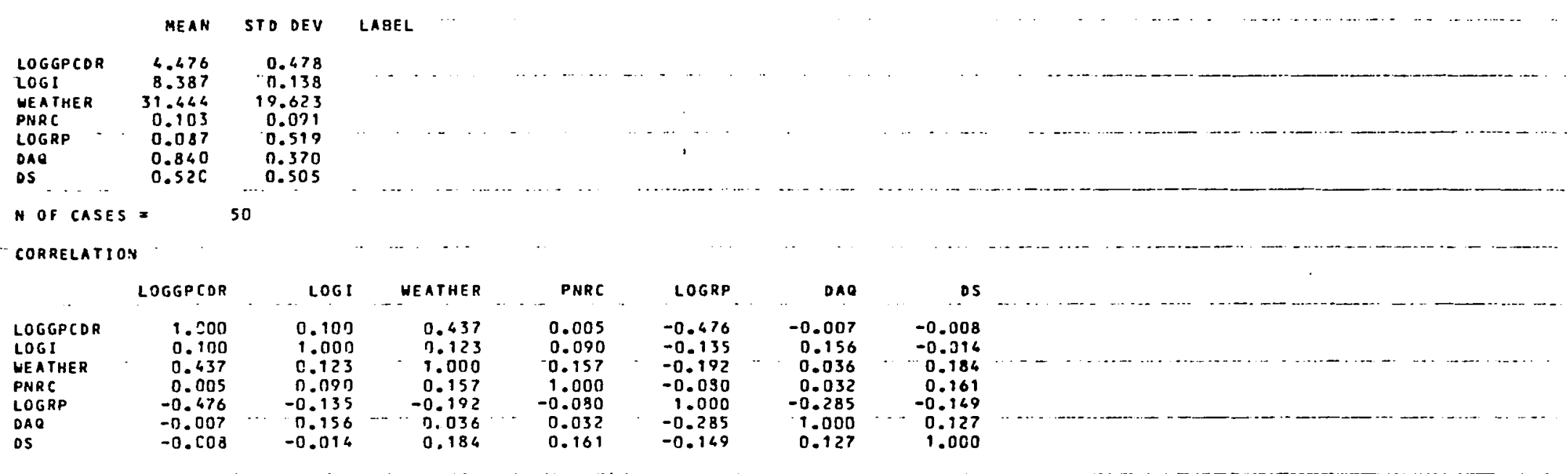


SPSS BATCH SYSTEA - UNIVERSITY OF KANSAS HONEYHELL CONVERSION

FILE WATER (CREATION DATE $=11-06-84) 3$

EQUATION Number 1.

DEPENDENT VARIABLE.. LOGGPCDR

BEgINAING BLOCK NUREER 1. METHOD: STEPHISE

-STEP MULTR RSO ADJPSO . F(EQU) SIGF

\begin{tabular}{|c|c|c|c|c|c|c|}
\hline $\begin{array}{l}\text { HULTR } \\
0.6759 \\
0.5922 \\
0.6091 \\
0.6218\end{array}$ & $\begin{array}{l}\text { RSO } \\
0.2265 \\
0.3507 \\
0.3703 \\
0.3860\end{array}$ & $\begin{array}{l}\text { ADJRSO } \\
0.2106 \\
0.3231 \\
0.3298 \\
0.3321 \\
0.3221\end{array}$ & $\begin{array}{l}F(E Q U) \\
16.054 \\
12.693 \\
9.037 \\
7.092 \\
5.655\end{array}$ & $\begin{array}{l}\text { SIGF } \\
0.060 \\
0.060 \\
0.000 \\
0.000 \\
0.000\end{array}$ & $\begin{array}{l}\text { RSOCH } \\
0.2265 \\
0.1242 \\
0.0201 \\
0.0158 \\
0.0046 \\
0.0007\end{array}$ & $\begin{array}{r}\text { FCH SIGCH } \\
14.0560 .000 \\
8.9920 .004 \\
1.4710 .231 \\
1.1600 .287\end{array}$ \\
\hline
\end{tabular}

5.0 .62550 .39120 .3221

7.896

VARIAaLE(S) ENTEREO ON STEP NUMBER '6.. - LOGI

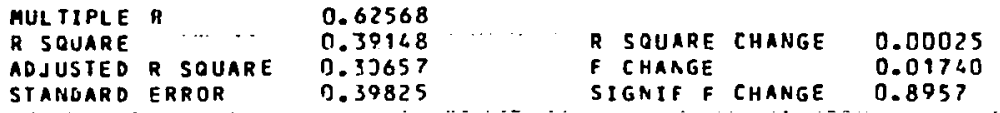

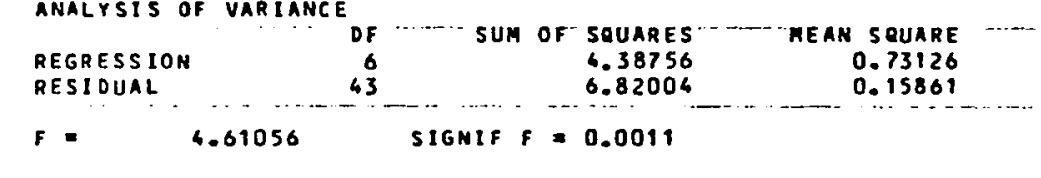

\begin{tabular}{|c|c|c|c|c|c|}
\hline YARIABLEE & B & SE $B$ & BETA & & SIG \\
\hline $\begin{array}{l}\text { LOGRP } \\
\text { WEATHER } \\
\text { OAR } \\
\text { OS } \\
\text { PNRC } \\
\text { LOGL } \\
\text { (CONSTANT) }\end{array}$ & $\begin{array}{r}-\Gamma .02674 \\
C .00937 \\
-0.17813 \\
-0.11277 \\
-C .37053 \\
0.05574 \\
3.99749\end{array}$ & $\begin{array}{l}0.11744 \\
0.00303 \\
0.16243 \\
0.11733 \\
0.64081 \\
0.42260 \\
3.52210\end{array}$ & $\begin{array}{r}-0.46278 \\
0.38446 \\
-0.13793 \\
-0.11900 \\
-0.07055 \\
0.01612\end{array}$ & $\begin{array}{r}-3.634 \\
3.089 \\
-1.097 \\
-0.961 \\
-0.578 \\
0.132 \\
1.135\end{array}$ & $\begin{array}{l}0.0007 \\
0.0035 \\
0.2789 \\
0.3679 \\
0.5661 \\
0.8957 \\
0.2627\end{array}$ \\
\hline
\end{tabular}

For block nUMger 1 POUT $=1.100$ Limits Reached. 
EQUATION (4) 


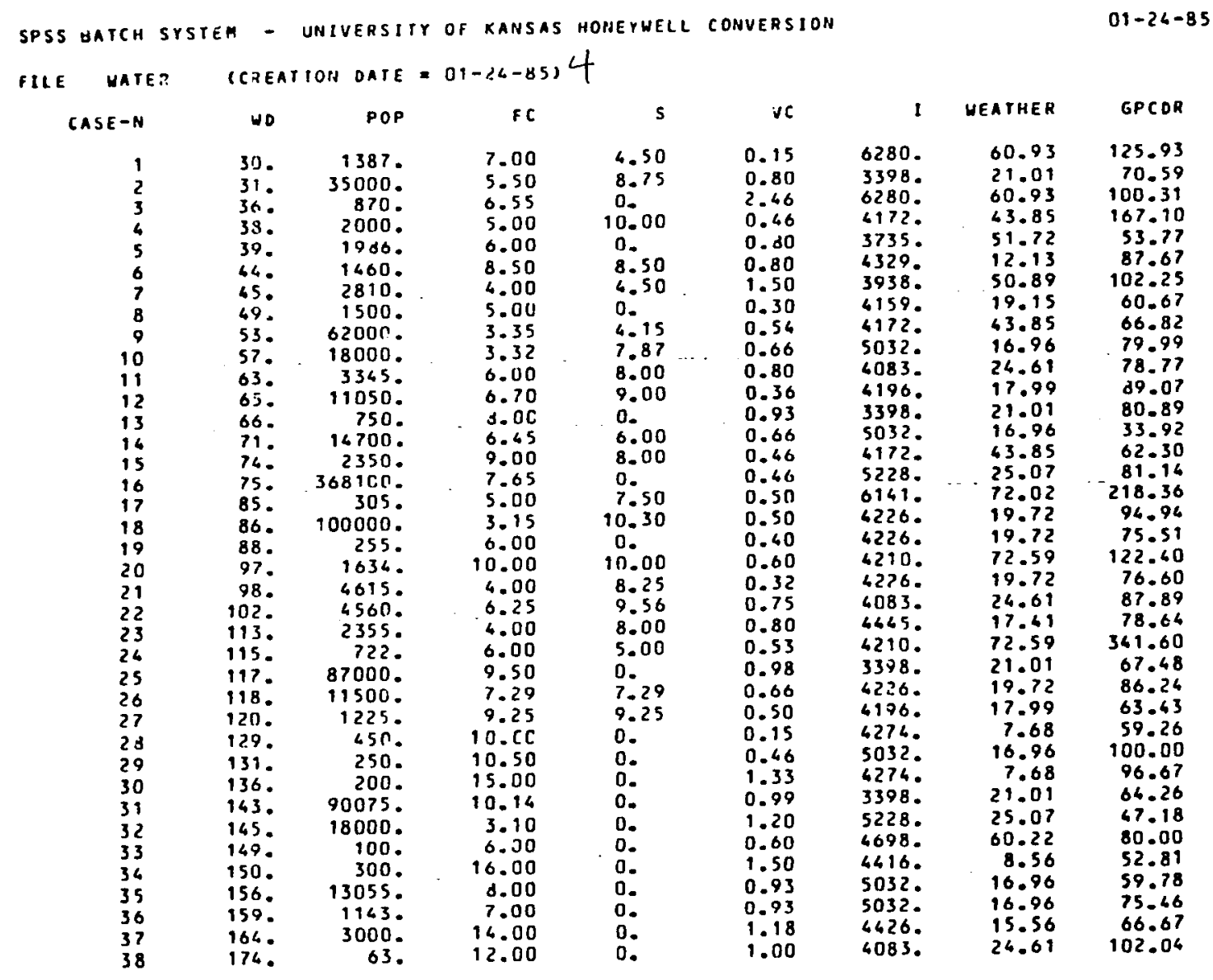


SPSS EATCH SYSTEM - UNIVERSITY OF KANSAS HOHEYUELL CONVERSION

FILE WATER (CREATION DATE $=01-26-85$ ) 4

VARIABLE PDP

\begin{tabular}{|c|c|c|c|c|c|}
\hline $\begin{array}{l}\text { MEAN } \\
\text { VARIANCE } \\
\text { RANGE } \\
\text { SUA }\end{array}$ & $\begin{array}{r}22845.132 \\
368037.000 \\
868115.000\end{array}$ & $\begin{array}{l}\text { STD ERROR } \\
\text { KURTOSIS } \\
\text { MINIMUM }\end{array}$ & $\begin{array}{r}10253.167 \\
25.206 \\
63.009\end{array}$ & $\begin{array}{l}\text { STO DEV } \\
\text { SXEUNESS } \\
\text { MAXIMUM }\end{array}$ & $\begin{array}{r}63204.766 \\
6.766 \\
368100.000\end{array}$ \\
\hline
\end{tabular}

SUM

38

MISSING OBSERVATIONS -

VARIABLE GPCOR

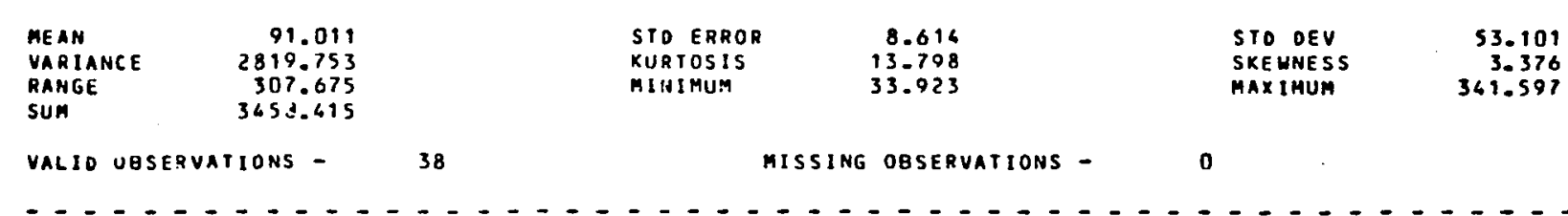

variagle ve

$\begin{array}{llllll}\text { MEAN } & 0.762 & \text { STD ERROR } & 0.071 & \text { STD OEV } & 0.439 \\ \text { VARIANCE } & 0.192 & \text { KURTOSIS } & 4.966 & \text { SKEENESS } & 1.737 \\ \text { RANGE } & 2.310 & \text { MINIMU.4 } & 0.15 C & \text { MAXIMUM } & 2.460 \\ \text { SUH } & 28.950 & & \end{array}$

VALID OBSERYATIONS - 38 MISSING OBSERVATIONS - 0

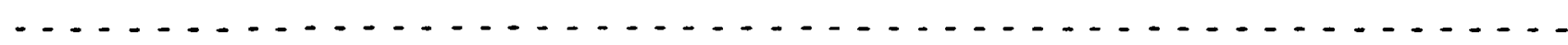

VARIAGLE fC

\begin{tabular}{lr} 
MEAN \\
VARIANCE \\
SANGE & 70.374 \\
\hline
\end{tabular}

$\begin{array}{lr}\text { VARIANCE } & 10.221 \\ \text { RANGE } & 12.900 \\ \text { SUA } & 280.200\end{array}$

$\begin{array}{ll}\text { STO ERROR } & 0.519 \\ \text { XURTOSIS } & 0.787 \\ \text { MINIMUY } & 3.105\end{array}$

$\begin{array}{ll}\text { STD DEV } & 3.197 \\ \text { SKEHNESS } & 0.980\end{array}$

SREHNESS

VALID OBSERVATIONS -

38

MISSING OBSERVATIONS -

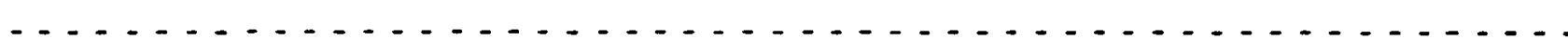


file Water (CREATION DATE $=09-24-85$ ) 4

\section{VARIABLE I}

$\begin{array}{lr}\text { MEAN } & 4669.579 \\ \text { VARIANCE } & 512022.629 \\ \text { RANGE } & 2882.000 \\ \text { SUM } & 169084.000\end{array}$

VALIO OBSERVATIONS -

38

$\begin{array}{lr}\text { STO ERROR } & 116.147 \\ \text { KURTOSIS } & 1.250 \\ \text { MIIIMUM } & 3398.000\end{array}$

STD OEV

$715.97 ?$

MAXIMUM $\quad 6280.000$
MISSING OBSERVATIOHS - 0

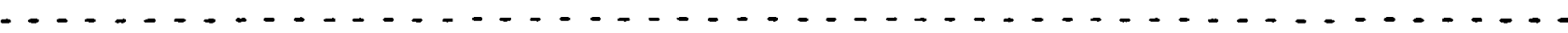

VARIAGLE HEATHER

$\begin{array}{lr}\text { MEAN } & 29.718 \\ \text { VARIANCE } & 377.864 \\ \text { RANGE } & 64.907 \\ \text { SUN } & 1129.286\end{array}$

VALID OBSERVATIONS KURTOSIS $\begin{array}{ll}\text { STO DEV } & 19.438 \\ \text { SKE YNESS } & 1.119 \\ \text { MAXIMUM } & 72.590\end{array}$

MISSIHG OBSERVATIONS - 0

VARIABLE $S$

MEAN

VARIANCE

RAIIGE

$$
\begin{array}{r}
4.064 \\
17.175 \\
10.300
\end{array}
$$

10.300
154.420

38

YAL TO GBSERVATIONS -

\begin{abstract}
STO ERRUR
KURTOSIS
MINIPUA
\end{abstract}

\section{STO DEV}

SKEHNESS
MAXIMUM

4.144

$\begin{array}{rl}-1.804 & \text { SKEHNESS } \\ 0.104 & 0.186\end{array}$

missing, observatioHs - 
SPSS uATCH SYSTEM - UNIVERSity OF Kansas HONEYWELl CONVERSiOH

EILE WATER (CREATION DATE $=19-09-84$ ) 4

- . multiple regeression.....

VARIable LIST nuMBer 1 . LISTHISE JELETION OF MISSING DATA.

MEAF. STD DEV LAGEL

$\begin{array}{lrr}\text { LGGGPCOR } & 4.414 & 0.416 \\ \text { LOGVC } & -0.423 & 0.577\end{array}$

LOGFC $\quad 1.91 \mathrm{C} \quad 0.627$

$\begin{array}{lrr}\text { LOG } & 8.389 & 0.153 \\ \text { LEATHER } & 29.718 & 19.438\end{array}$

$\begin{array}{lrr}\text { WEATHER } & \text { N.29.718 } & 19.438 \\ \text { DS } & 0.526 & 0.506\end{array}$

N OF CASES $=\quad 38$

CORRELATION

\begin{tabular}{|c|c|c|c|c|c|c|}
\hline & $\angle O G G P C D R$ & LoGVC & LOGFC & $\log I$ & WEATHER & os \\
\hline $\begin{array}{l}\text { LOGGPCDR } \\
\text { LOGVC } \\
\text { LUGFC } \\
\text { LOGI } \\
\text { WEATHER } \\
\text { OS }\end{array}$ & $\begin{array}{r}1 . c n 0 \\
-0.112 \\
-0.093 \\
0.170 \\
0.612 \\
0.343\end{array}$ & $\begin{array}{r}-0.112 \\
1.000 \\
0.167 \\
-0.110 \\
-0.062 \\
-0.273\end{array}$ & $\begin{array}{r}-0.093 \\
0.161 \\
1.000 \\
-0.133 \\
-0.233 \\
-0.448\end{array}$ & $\begin{array}{r}0.170 \\
-0.110 \\
-0.133 \\
1.000 \\
0.200 \\
-0.007\end{array}$ & $\begin{array}{r}0.612 \\
-0.062 \\
-2.233 \\
0.220 \\
1.000 \\
0.201\end{array}$ & $\begin{array}{r}0.343 \\
-0.278 \\
-0.448 \\
-0.307 \\
0.261 \\
1.000\end{array}$ \\
\hline
\end{tabular}


SPSS JATCH SYSTEM - UHIVERSITY OF KANSAS HONEYHELL COHVERSION

FILE WATER (CREATION DATE $=11-09-84) 4$

... multiple regress

EQUATIUN IUMBER 1.

DEPEILENT VARIABLE.. LOLUPCDR

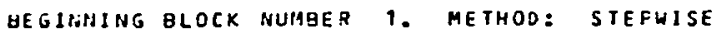

STEP MULTR RSO ADJRSE F(EQU) SIGF RSOCH

$\begin{array}{lllllll}1 & 0.6117 & 0.3762 & 0.3568 & 21.527 & 0 . C C 0 & 0.3762 \\ 2 & 0.0406 & 0.4106 & 0.3767 & 12.181 & 0.0 C C & 0.0362\end{array}$

$\begin{array}{llllllll}2 & 0.04562 & 0.4306 & 0.3804 & \ldots .571 & 0.005 & 0.0202\end{array}$

$\begin{array}{lllllll}4 & 0.6570 & 0.4317 & 0.3628 & 6.266 & 0.001 & 0.0011 \\ 5 & 0.6575 & 0.4324 & 0.3437 & 4.875 & 0.062 & 0.0007\end{array}$ 4.8750 .002 0.000

VARIAGLE(S) ENTEẼED ON STEP NUMBER S.. LUGVC

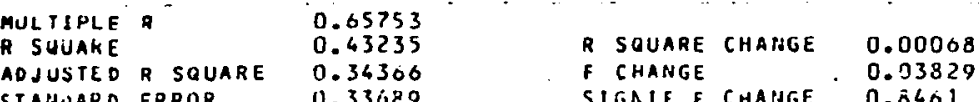
IN: WEATHER 0.207 0.280 1N: LST 0.0610 .806 IV: LOGI
0.0380 .846 IV: LOGV IN: LOGVC $\begin{array}{ll}\text { BETAIN } & \text { CORREL } \\ 0.6117 & 0.6117\end{array}$ 0.19710 .3434

$0.1605-0.0927$ $\begin{array}{rr}0.0363 & 0.1702 \\ -0.0274 & -0.1123\end{array}$

ADJUSTED R SQUARE 0.36306

CHGANGe change 0.00008

VARIABLES II" THE EQUATION

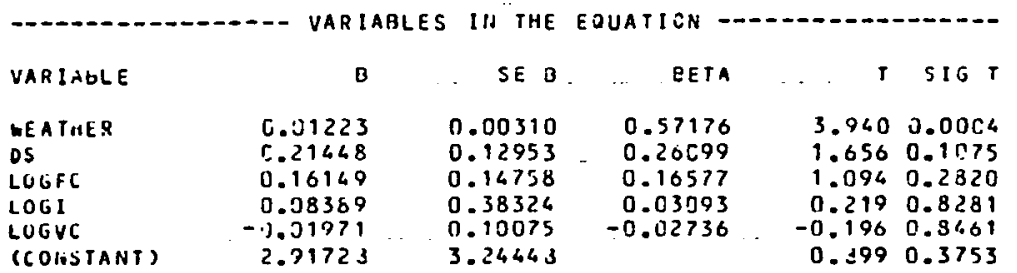

FOR ALOCK NUMEER 1 POUT = 1.100 LIHITS REACHED.

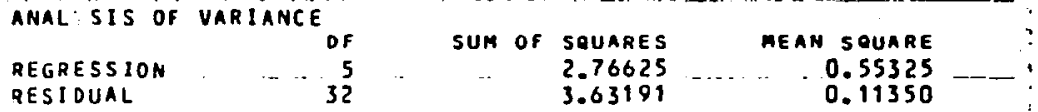

RESI DUAL

SIGNIF F $=0.0020$ 
131

EQUATION (5) 
SPSS GATCh SYSTEA - UNIVERSitY OH KanSAS hONEYHELl CONVERSiON

FILE WATER (CREATION DATE = 01-25-35) 5

CASE-
1
2
3
6
5
6
7
8
9
10
11
12
13
14
15
16
17
18
19
20
21
22
23
24
25
26
27
28
29
30
31

WD POP $F C$

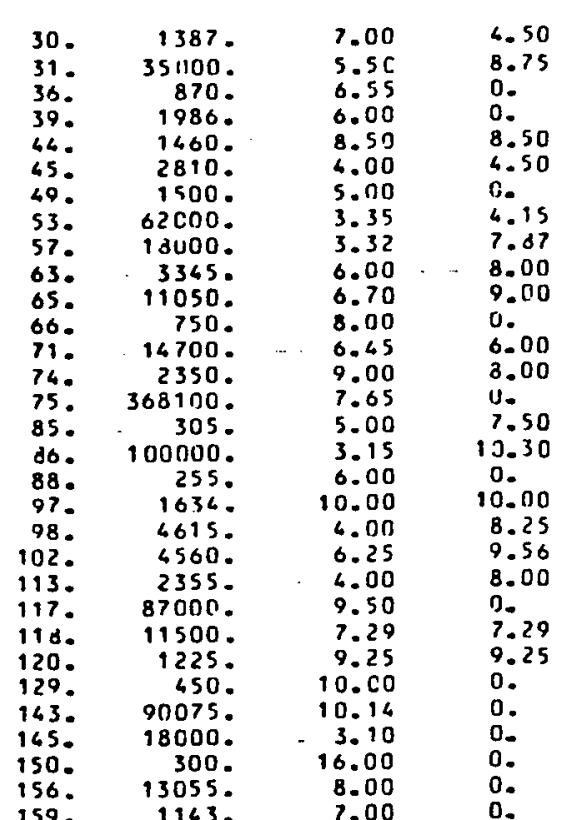

$01-25-85$

PAGE

1 HEATHER GPCOR

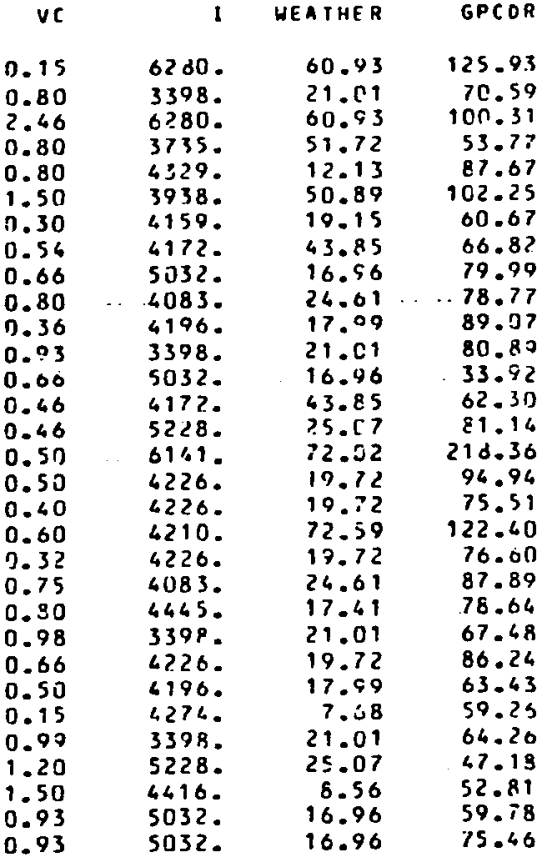


SPSS BATCH SYSTEP - UNIVERSIIY OF KANSAS HONEYHELL GONVERSION

FILE WATER (CREATION DATE $=01-26-85$ ) $\zeta$

VARIABLE POP

\begin{tabular}{|c|c|c|c|c|c|}
\hline $\begin{array}{l}\text { MEAN } \\
\text { VAR IANCE }\end{array}$ & $\begin{array}{r}27799.355 \\
.\end{array}$ & $\begin{array}{l}\text { STD ERROR } \\
\text { KURTOSIS }\end{array}$ & $\begin{array}{r}12429.189 \\
20.602\end{array}$ & $\begin{array}{l}\text { STO DEV } \\
\text { SKEWNESS }\end{array}$ & $\begin{array}{r}69702.795 \\
4.292\end{array}$ \\
\hline $\begin{array}{l}\text { RAMGE } \\
\text { SUM }\end{array}$ & $\begin{array}{l}367845.000 \\
86178 C .000\end{array}$ & MINIRUM & 255.000 & MAXIMUM & 368100.00 \\
\hline
\end{tabular}

SUA 861780.000

31

MISSING OBSERVATIONS - $\ldots 0$

31

0

VARIABLE GPCDR

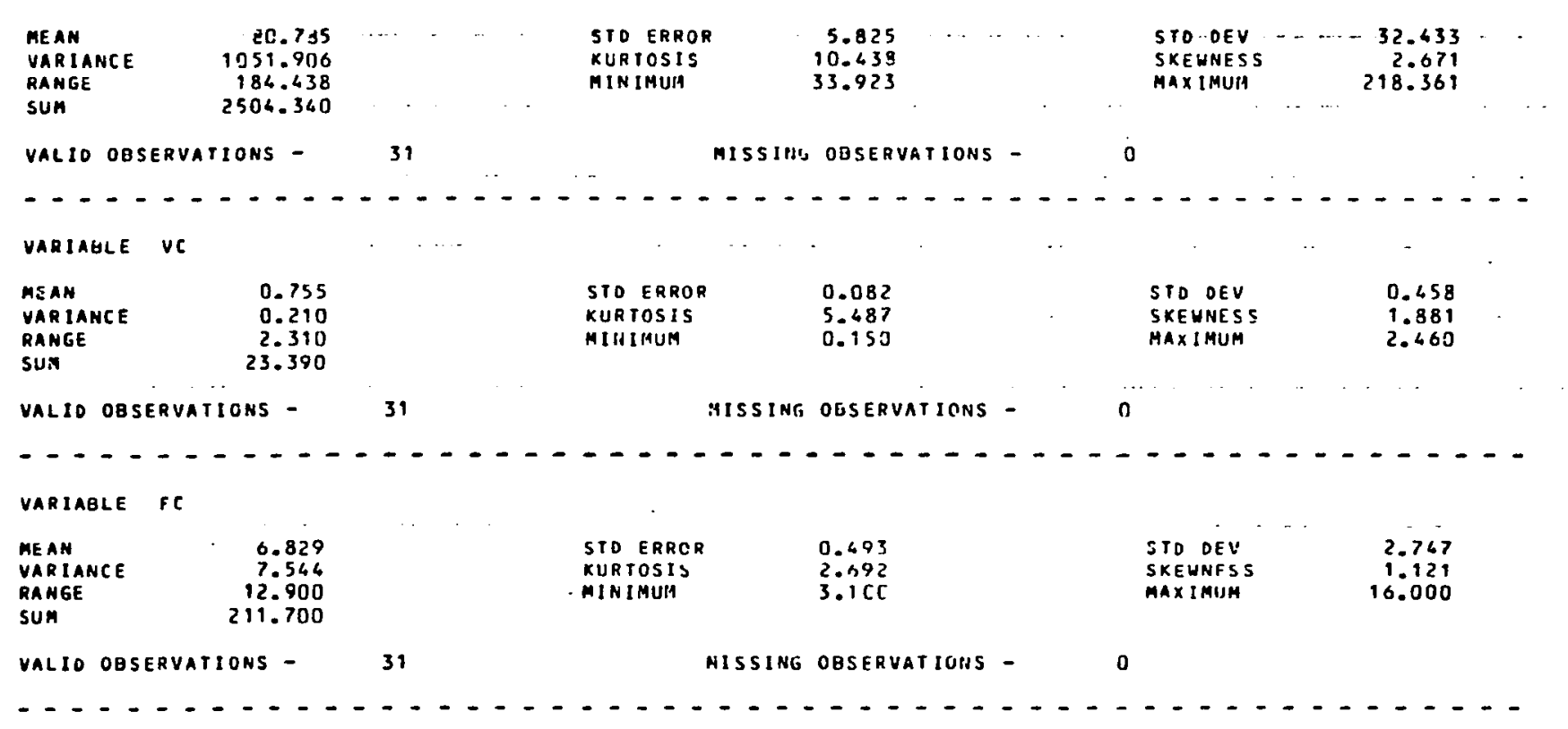


SPSS OATCH SYSTEM - UNIVERSITY OF KANSA5 HONEYUELL COAVERSTGH

FILE WATER (CREATION DATE $=01-26-85$ ) 5

VARIAGLE I

\begin{tabular}{|c|c|c|c|c|c|}
\hline $\begin{array}{l}\text { MEAN } \\
\text { YARIANCE }\end{array}$ & $\begin{array}{r}4457.710 \\
608794.946\end{array}$ & $\begin{array}{l}\text { STD ERRO } \\
\text { KLRTOSIS }\end{array}$ & $\begin{array}{r}140.138 \\
0.707\end{array}$ & $\begin{array}{l}\text { STD DEV } \\
\text { SKE NNESS }\end{array}$ & $\begin{array}{r}780.253 \\
0.976\end{array}$ \\
\hline RA HGE & 2 zद2-000 & MISIMUM & 3398.000 & MAXIMUM & 6280.000 \\
\hline
\end{tabular}

$\begin{array}{lr}608794.966 \\ \text { RAMGE } & 2222.000\end{array}$

SUN 138189.000

MIAIMUM

MISSING OASERYATIONS -

(n)

VARIAGLE WEATHER

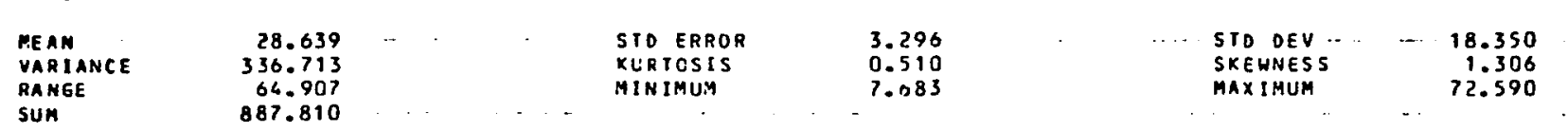

VALIO OBSERVATIONS - 31

MISSING OBSERVATIOHS -

VARIABLE $S$

$\begin{array}{lr}\text { MEAN } & 4.497 \\ \text { VARIANCE } & 17.031\end{array}$

$\begin{array}{ll}\text { RANGE } & 17.031 \\ \text { SUATE } & 10.300\end{array}$ 139.420

STD ERROR
KUPTOSIS

KURTOSIS
MINIIAUM

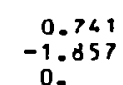

STO DEV

SKEYNESS
MAXIMUM

4.127
-0.040

-0.040
10.300

VALID OBSERUATIONS -

MISSING OQSERVAIIONS -

0 
SPSS BATCH SYSTEM - UNIVERSITY OF KANSAS hONEYUELL CONVERSIOM

FILE WATER (CREATION DATE $=11-19-86) 5$

-. nultiple regression....

- variagle list number i. listuise deletion of missing data.

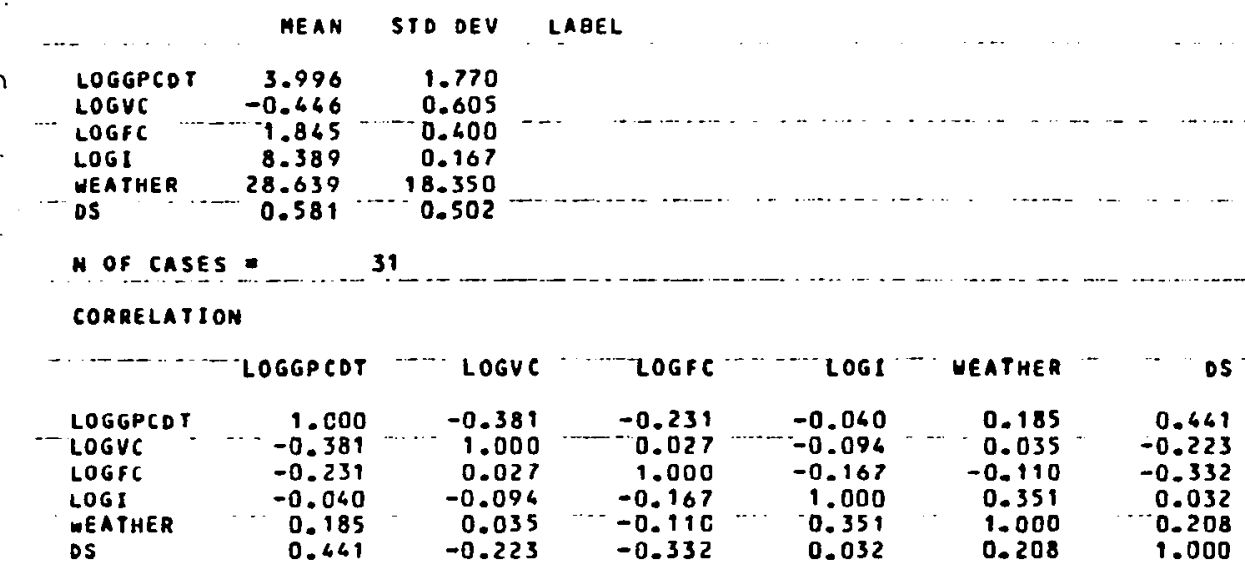


FILE HATER (CREATION DATE $=11-11-84) 5$

- * multiple tegression.....

EQUation number 1.

DEPENDENT VARIABLE.. LOGGPCDT

HEGINAING BLOCK NUMBER 1. METHOD: STEPUISE

STEP MULTR RSO AOJRSE F(EQU) SIGF RSOCH

$\begin{array}{llllllll}0.6409 & 0.1944 & 0.1666 & 0.997 & 0.013 & 0.1944\end{array}$

$\begin{array}{lllllll}2 & 0.5279 & 0.2787 & 0.2271 & 5.608 & 0.010 & 0.0863 \\ 3 & 0.5615 & 0.2933 & 0.2168 & 3.735 & 0.023 & 0.0166\end{array}$

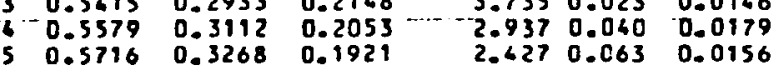

PCH SIGCH VARIABLE GETAIN CORREL L LABEL

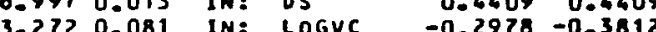

0.5580 .461 IN: UEATHER 0.1240 O. 1052

VARIABLE(S) ENTERED ON STEP NUMBER S.. LOGFE

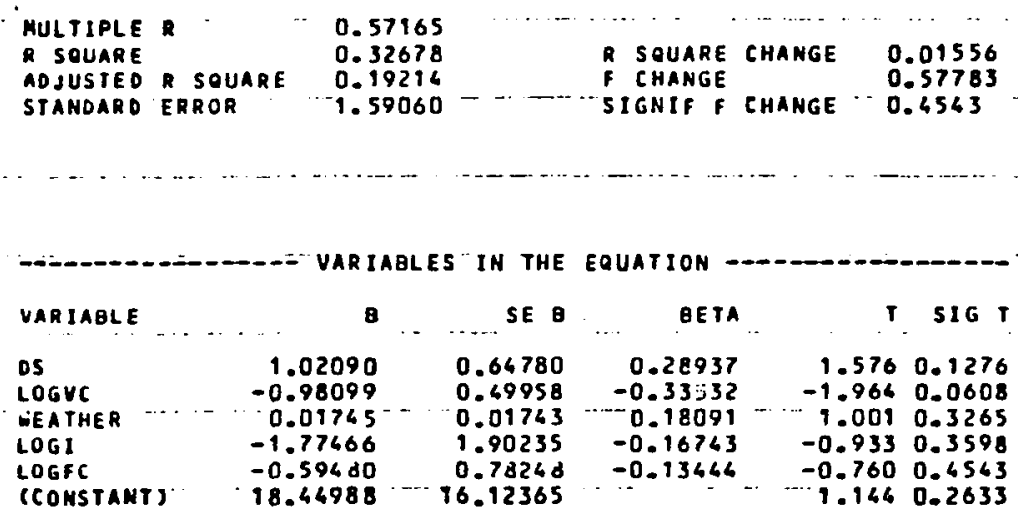

FOR BLOCK NUMBER 1 POUT $=1.100$ LIHITS REACHED. 
EQUATION (6) 
SPSS BATCH SYSTEM - UNIVERSITY OF XANSAS HONEYHELL CONVERSION

FILE UATER (CREATION DATE $=01-26-85$ ) 6

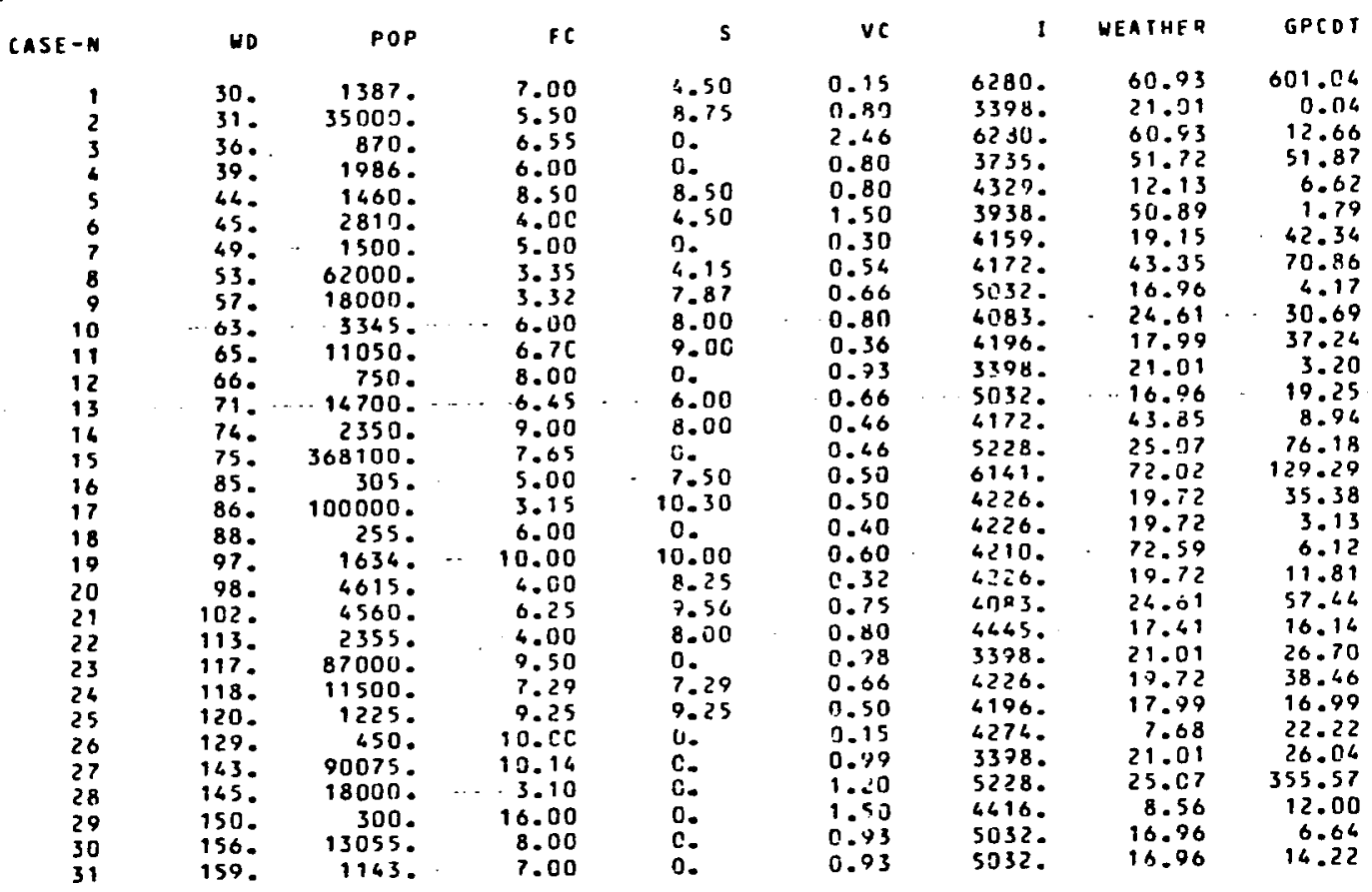


SPSS BATCH SYSIEP - UNIVERSITY OF KANSAS HONEYHELl CONVERSIOH

FILE WATER (CREATION OATE $=01-26-85)$ '

VARIAGLE POP

\begin{tabular}{|c|c|c|c|c|c|}
\hline $\begin{array}{l}\text { MEAN } \\
\text { VARIANCE } \\
\text { RANGE } \\
\text { SUM }\end{array}$ & $\begin{array}{r}27799.355 \\
367075.000 \\
367780.000\end{array}$ & $\begin{array}{l}\text { STO ERROR } \\
\text { KURTOSIS } \\
\text { MINIMUM }\end{array}$ & $\begin{array}{r}12429.189 \\
20.602 \\
255.000\end{array}$ & $\begin{array}{l}\text { SID DCV } \\
\text { SKEUNESS } \\
\text { MAXIMUM }\end{array}$ & $\begin{array}{r}69202.795 \\
4.292 \\
368100.000\end{array}$ \\
\hline
\end{tabular}

VALIO OBSERVATIONS - . 31

MISSING OQSERVATIONS -

VARIABLE GPCDT

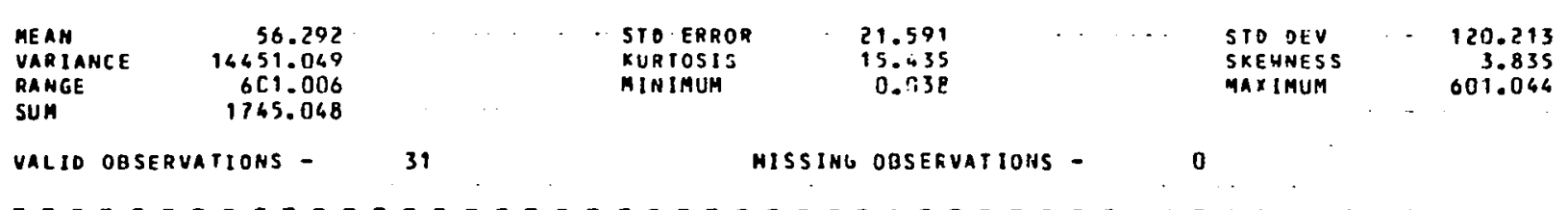

VARIAGLE VC

\begin{tabular}{|c|c|c|c|c|c|c|}
\hline $\begin{array}{l}\text { RE AH } \\
\text { VARI ANCE } \\
\text { RANGE } \\
\text { SUM }\end{array}$ & $\begin{array}{r}0.755 \\
0.290 \\
2.310 \\
23.390\end{array}$ & & $\begin{array}{l}\text { STD ERROR } \\
\text { KURTOSIS } \\
\text { MINIMUM }\end{array}$ & $\begin{array}{l}0.082 \\
5.487 \\
0.150\end{array}$ & $\begin{array}{l}\text { STD OEV } \\
\text { SKETINESS } \\
\text { MAKIMUM }\end{array}$ & $\begin{array}{l}0.658 \\
1.881 \\
2.460\end{array}$ \\
\hline VALIO OE & NS - & 31 & & OBSEEVATIONS - & 0 & \\
\hline
\end{tabular}

VAlio ogsenvations -

VARIABLE IC

\begin{tabular}{|c|c|c|c|c|c|}
\hline $\begin{array}{l}\text { MEAN } \\
\text { VARI IANCE } \\
\text { RANGE } \\
\text { SUE }\end{array}$ & $\begin{array}{r}6.829 \\
7.544 \\
12.990\end{array}$ & $\begin{array}{l}\text { STD ERROR } \\
\text { KURTOSIIS } \\
\text { WININUA }\end{array}$ & $\begin{array}{l}0.493 \\
2.692 \\
3.165\end{array}$ & $\begin{array}{l}\text { STO DEV } \\
\text { SXELINESS } \\
\text { MAXIMUM }\end{array}$ & $\begin{array}{r}2.767 \\
1.121 \\
16.000\end{array}$ \\
\hline
\end{tabular}

RANGE
SUA

31

MISSING OBSERVATIOHS: -

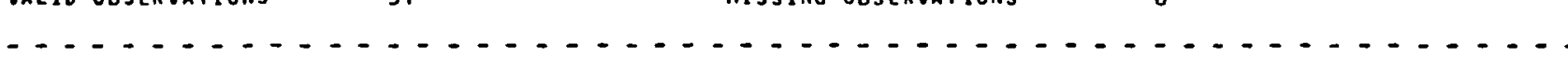


FILE WATER (CREATION DATE $=01-26-85) 6$

VARIAGLE I

\begin{tabular}{|c|c|c|c|c|c|}
\hline $\begin{array}{l}\text { MEAN } \\
\text { VARIANCE } \\
\text { RANGE } \\
\text { SUA }\end{array}$ & $\begin{array}{r}4457.710 \\
608794.946 \\
2422.000 \\
138189.000\end{array}$ & $\begin{array}{l}\text { STD ERROR } \\
\text { KLR TOSIS } \\
\text { MINIMUM }\end{array}$ & $\begin{array}{r}149.138 \\
0.707 \\
3398.090\end{array}$ & $\begin{array}{l}\text { STD OEV } \\
\text { SKEWNESS } \\
\text { HAXIMU:A }\end{array}$ & $\begin{array}{r}786.253 \\
0.974 \\
3280.000\end{array}$ \\
\hline
\end{tabular}

VALID OgSERVATIONS - - ...3

MISSING ORSERVATIONS -

0

\section{VARIABLE MEATHER}

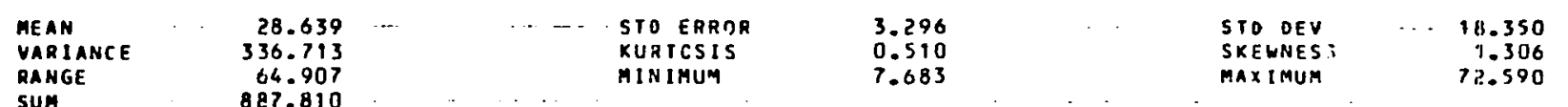

RANGE

SUA 827.810

MISSING JBSERVATIONS -

0

VALID OBSERVATIONS - 31 MISSING DESERYATIONS -

\section{VARIABLE $S$}

$\begin{array}{lr}\text { MEAN } & 4.497 \\ \text { VARIANCE } & 17.031\end{array}$

$\begin{array}{ll}\text { VARIANCE } & 17.031 \\ \text { PAHGE } & 10.300\end{array}$

$\begin{array}{lr}\text { RANGE } & 10.300 \\ \text { SUA } & 139.420\end{array}$

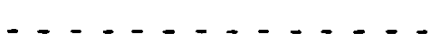

$\ldots \ldots \ldots$

VALIO OBSERVATIONS - 3

\section{SID ERROR}

KURTOSIS

MINIMUM

0.741
-1.857
0.

STS DEV

0.127

MAXIMUM $\quad-0.040$

MISSING OBSERVATIONS - 
SPSS BATCH SYSTEM - UNIVERSITY OF KANSAS HONEYWELL CONVERSION

GILE Hater (Creation DATE = 11-11-84)6

-.. hultiple regression.....

VARIAGLE LIST NUMBER 1. LISTHISE OELETION OF MISSING DATA.

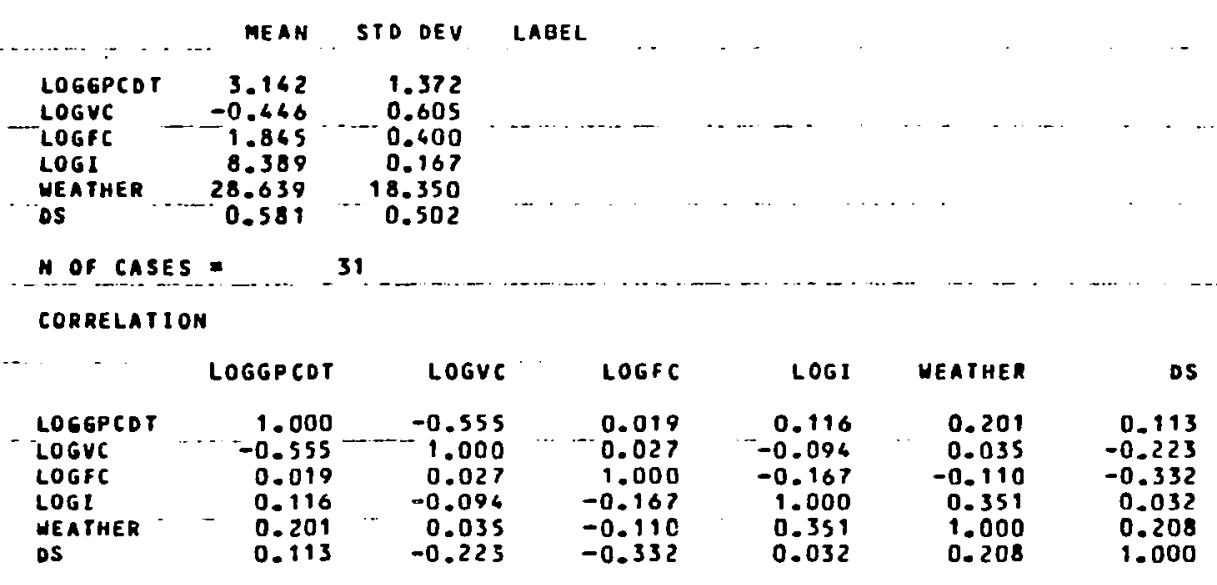


SPSS BATCH SYSTEA - UNIVERSITY OF KANSAS HONEYHELl CONVERSION

$11-11-84$

PAGE 7

FILE Mater (CREATION DATE $=11-11-06) G$

EQUATIOH HUMBER 1.

DEPENDENT VARIABLE.. LOGGPCOT

- aeginhing block number 1. method: StepHISE

STEP MULTR RSO ADJRSO F(EQU) SIGF ASOCH

$\begin{array}{lllllll}1 & 0.5554 & 0.3684 & 0.2846 & 12.934 & 0.001 & 0.3084\end{array}$

$\begin{array}{llllll}0.5976 & 0.3571 & 0.3192 & 7.777 & 0.002 & 0.0487\end{array}$

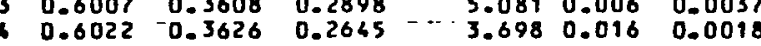
$2.8470 .036 \quad 0.0002$

$\begin{array}{rl}\text { BCH SIGCH } \\ -12.936 & 0.009\end{array}$ 12.936
2.120
2.00156 0.1570 .695 IN:

$\begin{array}{ll}0.072 & 0.799 \\ 0.007 & 0.932\end{array}$

VARIABLE BETAIN CORREL

LABEL

0.60230 .3628

0.2353

BETAIN CORREL
$-0.5554-0.5554$

$0.2208 \quad 0.2009$

$0.0646-0.0195$

VARIABLE (S) ENTERED ON STEP NUMBER 5.. LOGI

MULTIPLE R

SQUARE 0.60231

ADJUSTED R SOUARE 0.23534

CHANGE CHAMGE

0.00019

$1.23534 \ldots 001 . . . . . .5$ CHAMGE

.............

VARIABLES IN THE EQUATIOH

\begin{tabular}{|c|c|c|c|c|}
\hline VARIABLE & B & SE $B$ & BETA & T SIG T \\
\hline $\begin{array}{l}\text { LOGVC } \\
\text { WEATHER } \\
\text { DS } \\
\text { LOGFC } \\
\text { LOGI } \\
\text { COOSTANT }\end{array}$ & $\begin{array}{r}-1.31092 \\
0.01809 \\
-0.13994 \\
0.14442 \\
-0.12394 \\
2.89312\end{array}$ & $\begin{array}{l}0.37690 \\
0.01315 \\
0.48873 \\
0.59033 \\
1.43521 \\
12.16431\end{array}$ & $\begin{array}{r}-0.57786 \\
0.26186 \\
-0.05115 \\
0.04210 \\
-0.01508\end{array}$ & 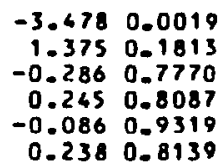 \\
\hline
\end{tabular}

FOR BLOCK NUMBER 1 POUI $=1.100$ LIMITS REACHED. 
EQUATION (7) 
SPSS GATCH SYSTEA - UNIVERSTTY OF KANSAS HONEYHCLL CONVERSTIJN

FILE WATER (CREATION DATE $=01-25-85$ ) 7

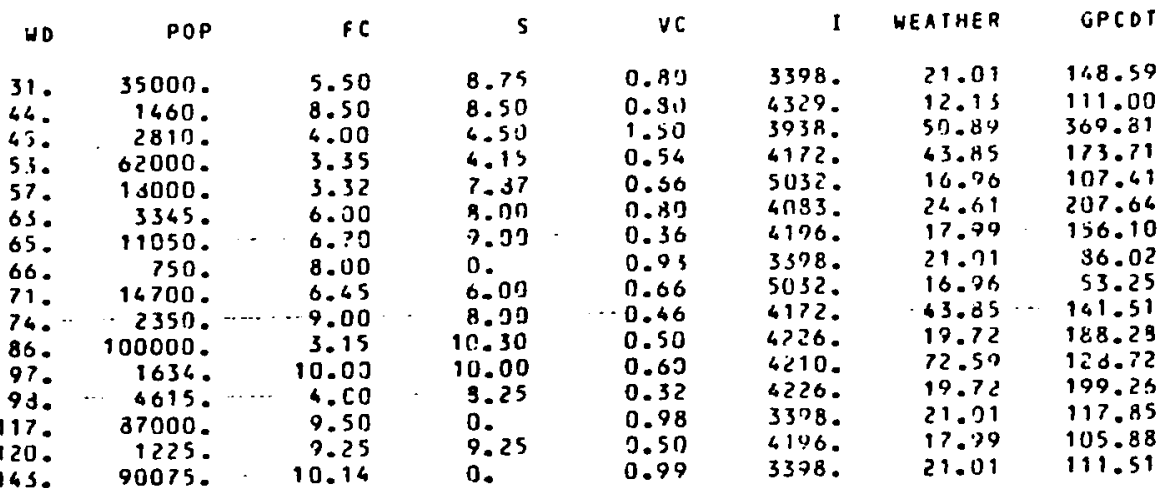


SPSS BATCH SYSTEN - UNIVERSITY OF KANSAS HONEYHELL CONVERSION

\section{FILE WATER (CREATION DATE $=01-26-85$ ) 7}

VARIABLE pop

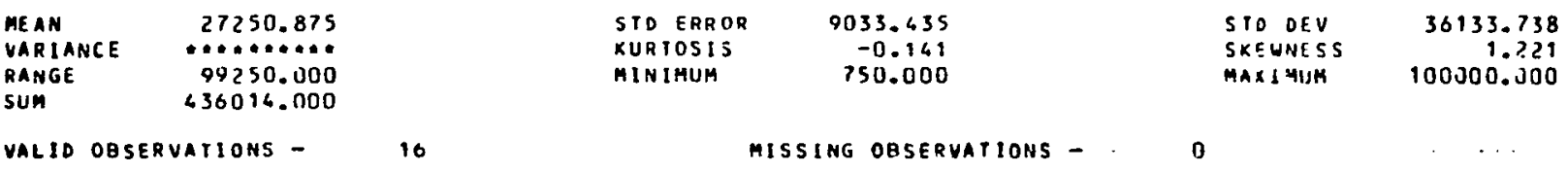

MISSING OBSERVATIONS -

VARIAQLE GPCDT

\begin{tabular}{|c|c|c|c|c|}
\hline $\begin{array}{l}\text { MEAN } \\
\text { VARIANCE } \\
\text { RAHGE } \\
\text { SUA }\end{array}$ & $\begin{array}{r}150.409 \\
5193.637 \\
316.564 \\
2406.546\end{array}$ & $\begin{array}{l}\text { SID ERROR } \\
\text { KURTOSIS } \\
\text { MINIMUY }\end{array}$ & $\begin{array}{r}18.017 \\
5.362 \\
53.268\end{array}$ & $\begin{array}{l}\text { STO OEV } \\
\text { SKEEINESS } \\
\text { MAXIMUM }\end{array}$ \\
\hline
\end{tabular}

VALID OBSERVATIONS - 16 MISSING OBSERVATIONS - 0

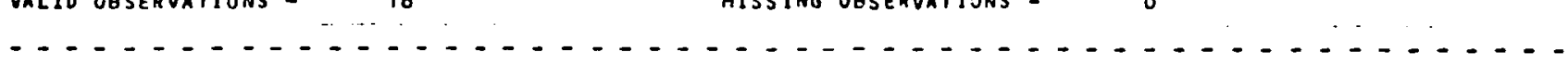

VARIABLE VC

$\begin{array}{lrllll}\text { MEAN } & 0.712 & \text { STOERROR } & 0.076 & \text { STE OEV } & 0.297 \\ \text { VARIANCE } & 0.088 & \text { KURTOSIS } & 2.041 & \text { SKEWNESS } & 1.153 \\ \text { RANGE } & 1.100 & \text { MINIMUM } & 0.320 & \text { MAXIMUM } & 1.500 \\ \text { SUA } & 11.400 & & \end{array}$

VALID OBSERVATIONS - 16 MISSING OBSERVATIOHS - D

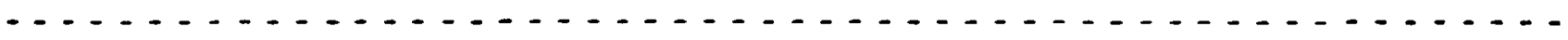

VARIABLE FC

\begin{tabular}{|c|c|c|c|c|c|}
\hline $\begin{array}{l}\text { ME AN } \\
\text { VARIANCE } \\
\text { RANGE } \\
\text { SUH }\end{array}$ & $\begin{array}{r}6.679 \\
6.607 \\
6.990 \\
106.860\end{array}$ & $\begin{array}{l}\text { STD ERROR } \\
\text { XURTOSSIS } \\
\text { MINIMUM }\end{array}$ & $\begin{array}{r}0.663 \\
-1.596 \\
3.150\end{array}$ & $\begin{array}{l}\text { STD DEY } \\
\text { SKEWNESS } \\
\text { MAXI IMUM }\end{array}$ & $\begin{array}{r}2.570 \\
-0.093 \\
10.160\end{array}$ \\
\hline
\end{tabular}

VALID OBSERVATIONS - $16 \quad$ HISSING OBSERVATIONS - 0 
SPSS BATCH SYSTEM - UNIVERSITY OF KANSAS HONEYHELL CONVEISSION

file water (CREATION DATE $=01-26-85$ )

YARIAGLE I

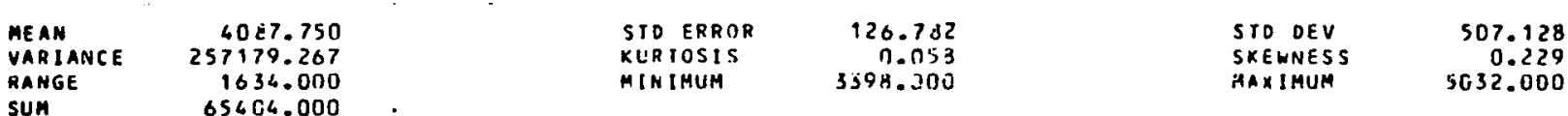

KIRTOSIS

359.300

HAXIMUM

032.000

VALID OBSERVATIONS - $16 \quad-\quad \ldots \quad$ MISSIHG OBSERVATIONS - $\quad$ - 0

1

VARIABLE MEATHER

\begin{tabular}{|c|c|c|c|c|c|}
\hline $\begin{array}{l}\text { MEAN } \\
\text { UARIANCE } \\
\text { RAHGE } \\
\text { SUM }\end{array}$ & $\begin{array}{r}27.581 \\
270.124 \\
60.462 \\
461.298\end{array}$ & $\cdots$ & $\begin{array}{l}\text { STO ERROR } \\
\text { KURTOSIS } \\
\text { MIHIMUM }\end{array}$ & $\begin{array}{r}4.109 \\
2.046 \\
12.129\end{array}$ & $\begin{array}{lr}\text { STO DEV } & 16.435 \\
\text { SKEWNESS } & 1.758 \\
\text { HAXIMUM } & 72.590\end{array}$ \\
\hline
\end{tabular}

VALIO OBSERVATIONS - $16 \quad$ MISSING OBSERUATIOHS - 0

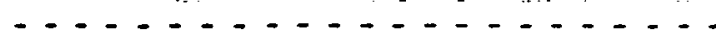

vartagle $S$

$\begin{array}{rr}\text { MEAN } & 6.411 \\ \text { VARIAMCE } & 13.027\end{array}$

RANGE 10.300

$102.57 \mathrm{C}$

STO ERROR

KURTOSIS

MINIMUM

0.202
-0.369

- 0.

STD OEV

3.609
-1.012

VALIO OBSERVATIONS -

MISSING OBSERVATIONS -

0 
SPSS BATCH SYSTEM - UNIVERSITY OF KANSAS HONEYHELL CONUERSION

FILE WATER (CREATION DATE $=11-11-86) 7$

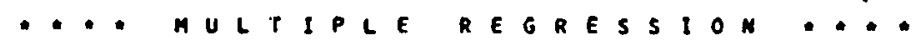

I variagle list number 1. Listuise deletion of hissing oata.

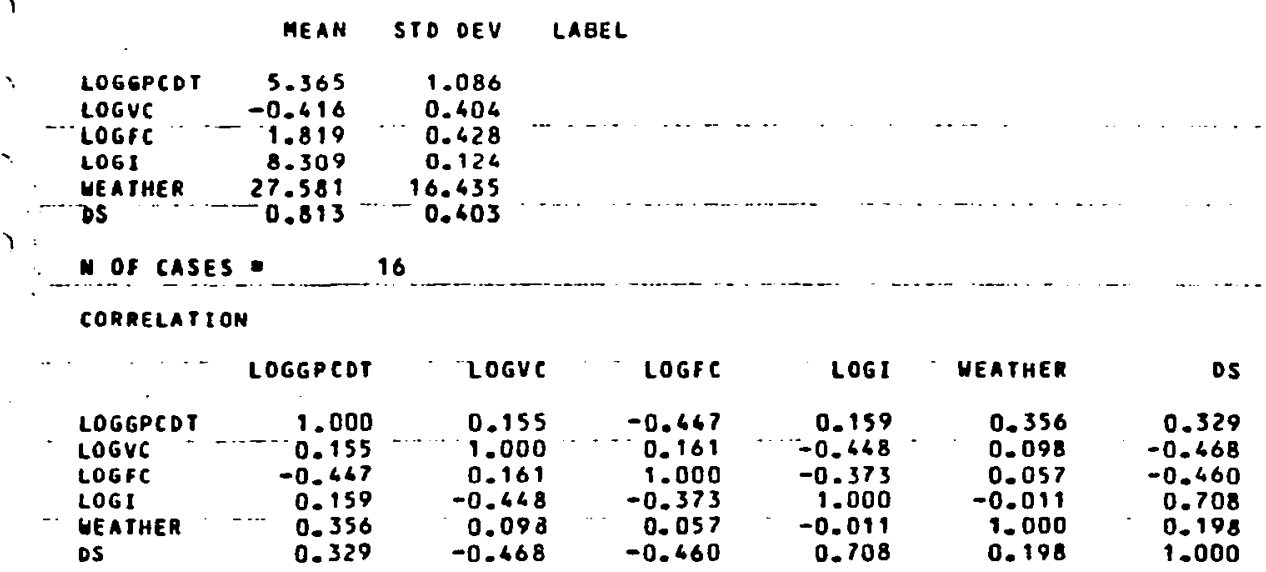


SPSS BATCH SYSTEA - UNIVERSITY OF KANSAS HONEYWELL CONUERSION

$11-11-84$

PAGE T

PILE WATER (CREATION OATE $=11-11-84) 7$

-.. MULI1PLE REgRESSIOn....

EQUATION NUMBER 1.

DEPENDENT VARIABLE.. LOGGPCOT

aeginning block number 1. methoo: StepHISE

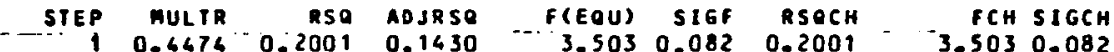

$\begin{array}{lllllll}2 & 0.5886 & 0.3665 & 0.2459 & 3.646 & 0.063 & 0.1463\end{array}$

$\begin{array}{lllllll}3 & 0.6207 & 0.3853 & 0.2316 & 2.507 & 0.109 & 0.0388\end{array}$

$\begin{array}{lllllll}5 & 0.6610 & 0.6109 & 0.1967 & 1.918 & 0.178 & 0.0257 \\ & 0.6613 & 0.6113 & 0.1969 & 1.397 & 0.305 & 0.0003\end{array}$

3.5030 .082

2.911

0.7570 .401

0.0060 .940

VARTABLE DETAIN CORREL

IN: WEATHER 0.38310 .3562

VARIABLE(S) ENTERED ON STEP MUMBER S.. LOGI

$\begin{array}{lllll}\text { MULTIPLE } & 0.64129 & & & \\ \text { R SQUARE } & 0.69126 & & \text { R SOUARE CHANGE } & 0.00035 \\ \text { ADJUSTED R SQUARE } & 0.11689 & \ldots & \text { F CHANGE } & 0.00594\end{array}$

ADJusted r souare - 0.11689 ... ......

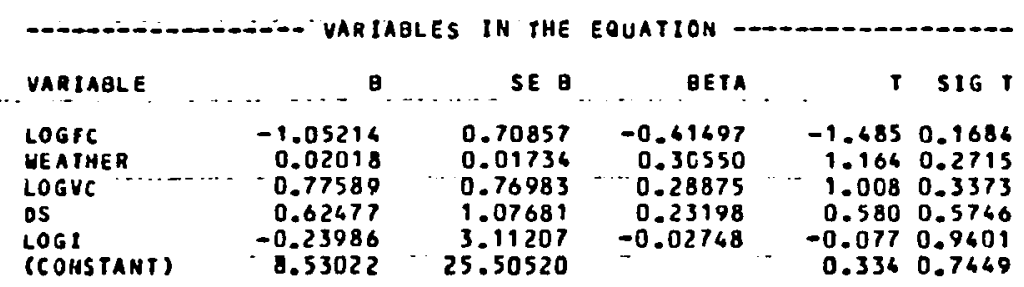

FOR BLOCK NUMBER 1 POUT $=1.100$ LIMITS REACHED. 
EQUATION (8) 
SPSS BATCH SYSTEM - UNIVERSITY OF KANSAS HONEYHELL COHUERSION

$01-26-15$

PAGE 6

FILE WATER (CREATION DATE $=01-20-85$ ) 8

CASE-N
1
2
3
4
5
6
7
8
9
9
-10
11
12
-13
14
15
16
17

HD POP FC

$\begin{array}{cr}5 & v c \\ 8.75 \cdots & 0.80 \\ 8.50 & 0.80\end{array}$

\begin{tabular}{|c|c|}
\hline $\begin{array}{l}31 . \\
44 . \\
450 \\
53 . \\
57 . \\
63 . \\
65 . \\
66 . \\
710 \\
74 . \\
36 . \\
97 . \\
98 . \\
115 . \\
117 . \\
120 . \\
163 .\end{array}$ & 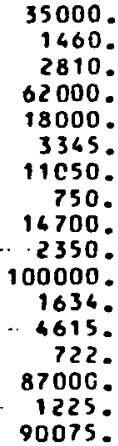 \\
\hline
\end{tabular}

5.50
8.50

6.00

$3.5 \mathrm{C}$

0.80
1.50
0.54

1.50
-0.54

4.15
7.87

0.00
6.32

$6.00 \quad 8.00$

9.00

0.54
0.66
0.80

0.80

0.93

0.66

$\begin{array}{rr}0.45 & 0.00 \\ 3.00- & -8.00\end{array}$

$-0.66$

$10.15 \quad 10.30 \quad 0.50$

$\begin{array}{ll}3.15 & 10.30 \\ 0.00 & 10.00\end{array}$

.000 .25

$0.00 \quad 5.00 \quad 0.53$

0.60

0.53
0.98
0.50
0.99

0.99

1 HEATHER GPCDT

3398. $21.01 \quad 77.97$

$39350 \quad 50.59 \quad 265.77$

4172 . $43.35 \quad 36.03$

5032. $\quad 16.96 \quad 23.03$

4083. $24.61 \quad 98.17$

6196 - 17.99 . 29.80

3398. $\quad 21.01 \quad 1.93$

5032. $16.96 \quad 0.07$

$6172 . \cdots-63.35 \cdots 70.28$

4226. $\quad 19.72 \quad 57.95$

$42100 \quad 72.59 \quad 0.20$

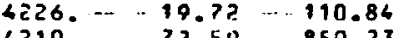

$72.59 \quad 850.23$

196. - $17.99 \quad 25.66$ 
SPSS GATCH SYSTEM - INIVFRSITY OF KANSAS hONEYWELl CONVERSiON

VARIAOLE POP

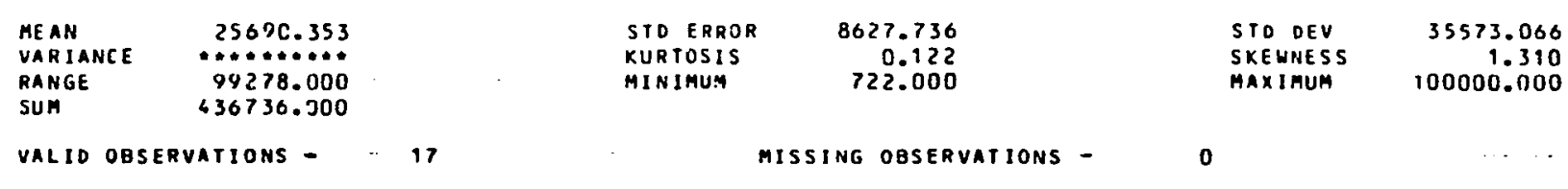

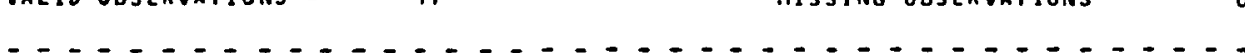

VARIABLE GPCOT

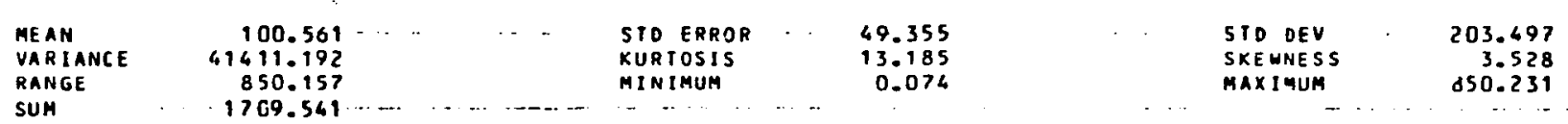

VALIO OBSERVATIONS - 17 MISSING OASERVATIONS - 0

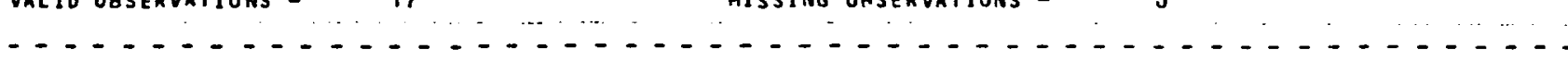

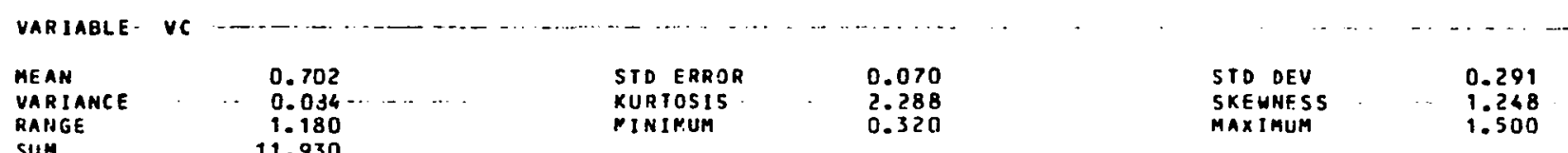

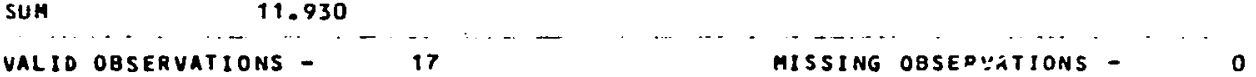

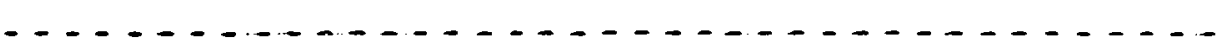

\section{VARIABLE FC}

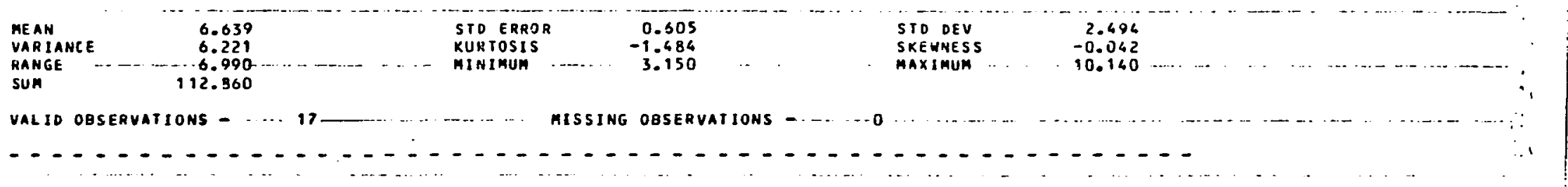


SPSS BATCH SYSTEA - UNIVERSITY OF KANSAS HONEYGELL CONGERSION

FILE WATER (CREATION OATE $=01-26-85) \&$

VARIABLE I

\begin{tabular}{|c|c|}
\hline $\begin{array}{l}\text { IEAM } \\
\text { ARIAANCE }\end{array}$ & $\begin{array}{r}4094.941 \\
241984.684 \\
1636.000\end{array}$ \\
\hline
\end{tabular}

RANGE
SUA

KURTOSIS

0.216
3398.000

MAXIMUM

5032.000

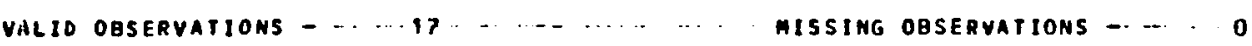

VARIABLE WEATHER

MEAH NARTE $\quad 372.40$

$\begin{array}{lr}\text { VARIANCE } & 372.407 \\ \text { RAMGE } & 60.462\end{array}$

$\begin{array}{cr}\text { STO-ERROR } & -6.680 \\ \text { KURTOSIS } & 0.913 \\ \text { MIHIMUM } & 12.129\end{array}$

0.913
12.129

SKEWNESS

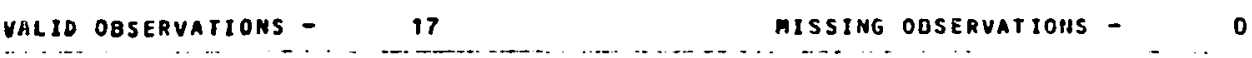

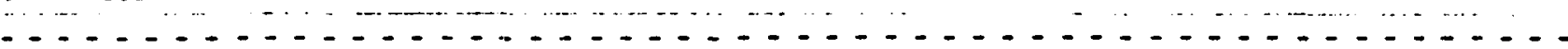

VARIAQLE S

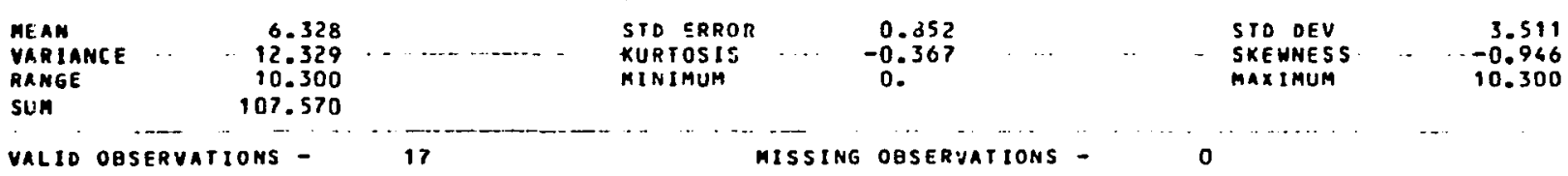

YAL IO OBSERYATIONS

MISSING OQSERUATIONS 


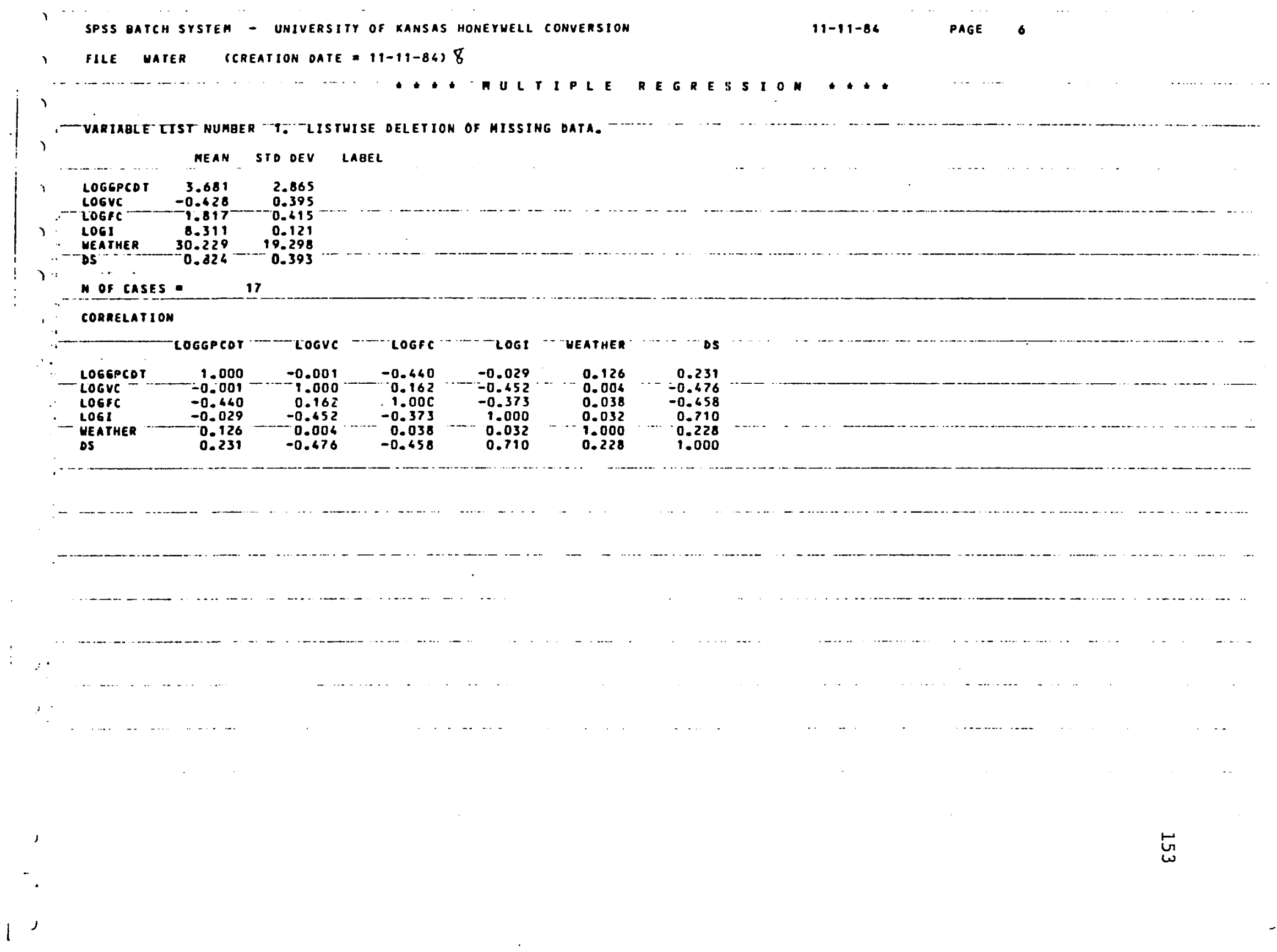




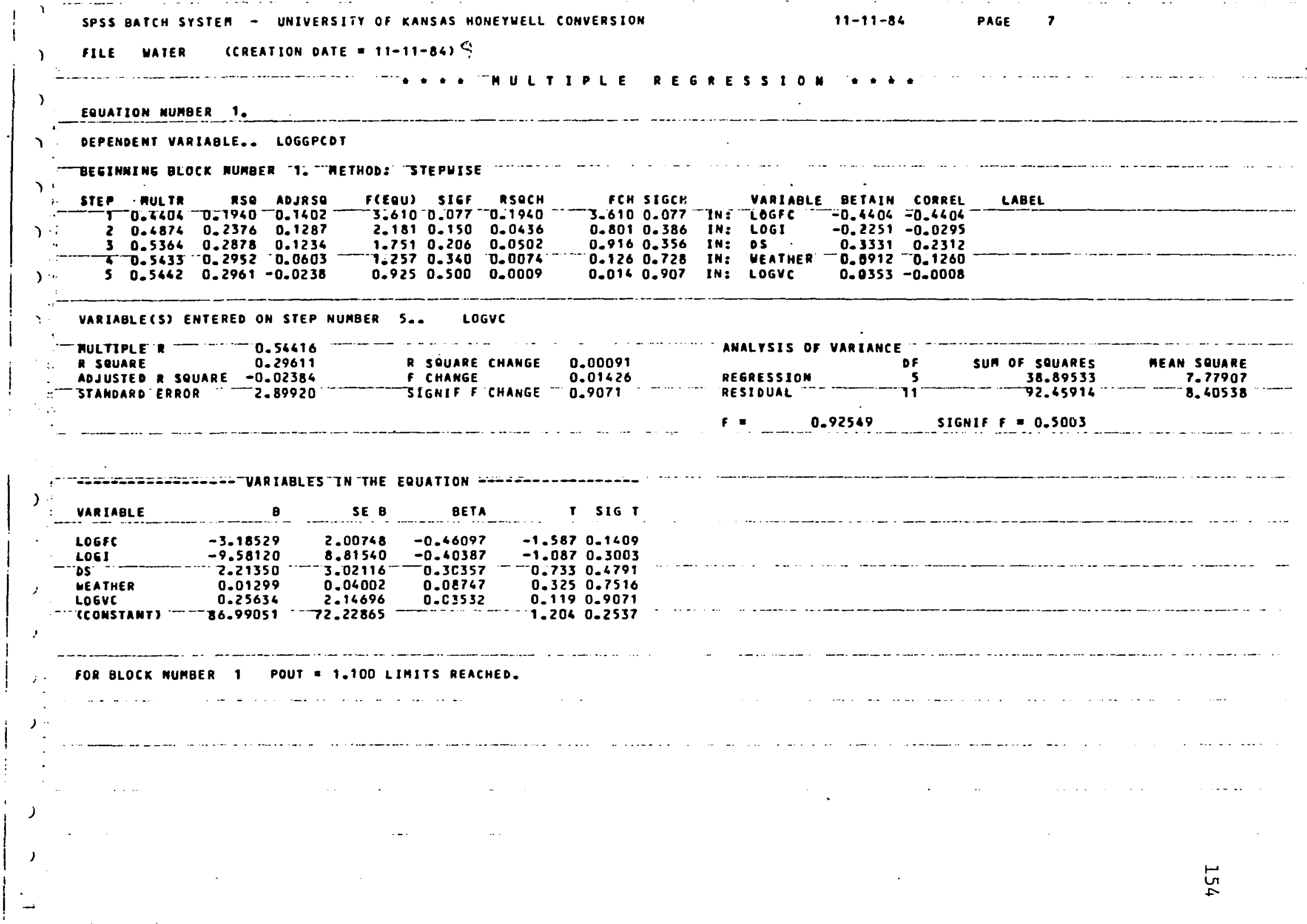

